c. 2

\title{
Geophysical Investigation at Fort Detrick, Maryland
}

\author{
by José Llopis, Janet E. Simms \\ Geotechnical Laboratory
}

Approved For Public Release; Distribution Is Unlimited

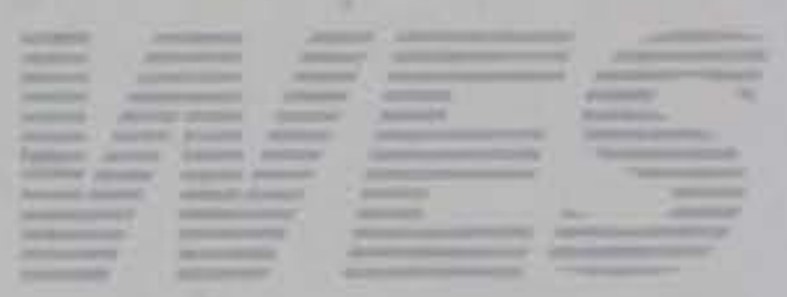

RESEARCH LIBRARY

US ARMY ENGINEER WATERWAYS

EXPERIMENT STATION

VICKSBURG, MISSISSIPPI 


\section{Geophysical Investigation at Fort Detrick, Maryland}

by José Llopis, Janet E. Simms

Geotechnical Laboratory

U.S. Army Corps of Engineers

Waterways Experiment Station

3909 Halls Ferry Road

Vicksburg, MS 39180-6199

Final report

Approved for public release; distribution is unlimited 


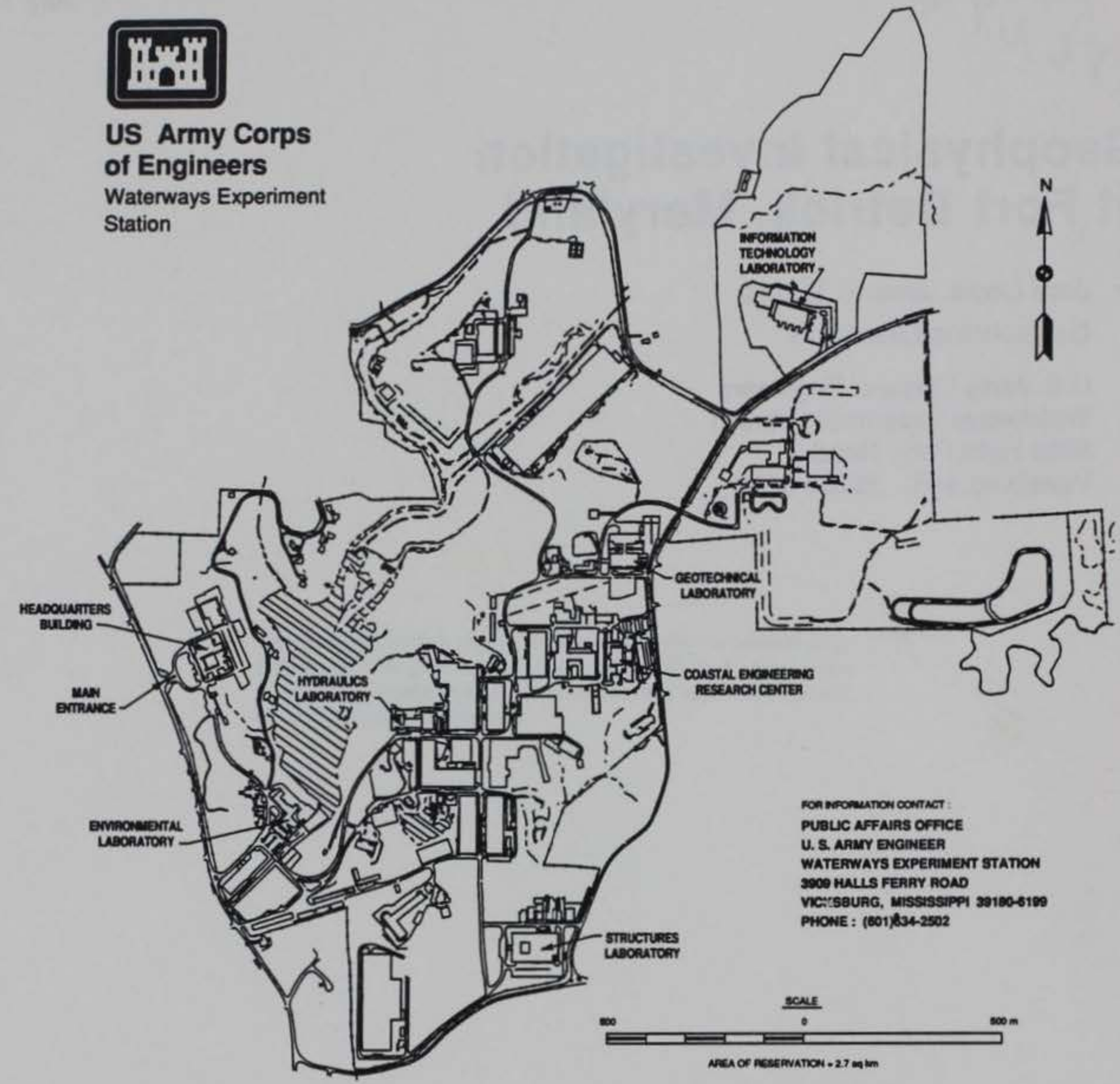

\section{Waterways Experiment Station Cataloging-in-Publication Data}

Llopis, José L.

Geophysical investigation at Fort Detrick, Maryland / by José Llopis, Janet E. Simms ; prepared for U.S. Army Environmental Center.

128 p. : ill. ; $28 \mathrm{~cm}$. - (Technical report ; GL-93-14)

Includes bibliographical references.

1. Hazardous waste sites - Maryland - Fort Detrick (Frederick, Md.)

2. Environmental monitoring - Maryland - Fort Detrick (Frederick, Md.)

3. Soil surveys - Maryland - Fort Detrick (Frederick, Md.) 4. Magnetic anomalies - Maryland - Fort Detrick (Frederick, Md.) - Geophysical methods. I. Simms, Janet E. II. U.S. Army Environmental Center. III. U.S. Army Engineer Waterways Experiment Station. IV. Title. V. Series: Technical report (U.S. Army Engineer Waterways Experiment Station) ; GL-93-14.

TA7 W34 no.GL-93-14 


\section{Contents}

Preface $\ldots \ldots \ldots \ldots \ldots \ldots \ldots \ldots \ldots \ldots \ldots \ldots \ldots \ldots \ldots \ldots \ldots, \quad v$

Conversion Factors, Non-Si to $\mathrm{Si}$ Units of Measurement $\ldots \ldots \ldots \ldots$ vi

1 -Introduction $\ldots \ldots \ldots \ldots \ldots \ldots \ldots \ldots \ldots \ldots \ldots \ldots \ldots$

Background $\ldots \ldots \ldots \ldots \ldots \ldots \ldots \ldots \ldots \ldots \ldots \ldots \ldots \ldots \ldots \ldots \ldots$

Objectives . . . . . . . . . . . 2

2-Area B Characteristics $\ldots \ldots \ldots \ldots \ldots \ldots \ldots \ldots \ldots \ldots \ldots \ldots$

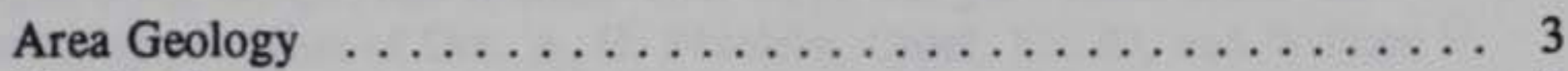

Site Geology . . . . . . . . . . . . . . . . 3

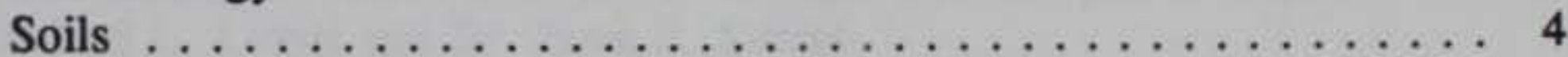

3-Geophysical Test Principles and Field Procedures $\ldots \ldots \ldots \ldots \ldots$

Geophysical Test Principles $\ldots \ldots \ldots \ldots \ldots \ldots \ldots \ldots \ldots .5$

Electromagnetic surveys $\ldots \ldots \ldots \ldots \ldots \ldots \ldots \ldots \ldots \ldots$

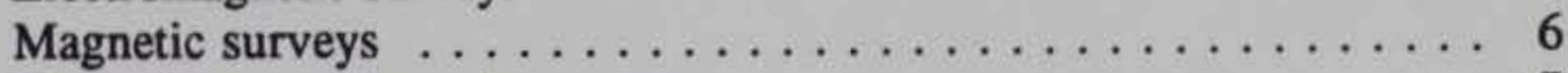

Ground penetrating radar surveys $\ldots \ldots \ldots \ldots \ldots \ldots \ldots 7$

Seismic refraction surveys $\ldots \ldots \ldots \ldots \ldots \ldots \ldots \ldots \ldots .8$

Field Procedures $\ldots \ldots \ldots \ldots \ldots \ldots \ldots \ldots \ldots \ldots \ldots$

4-Test Results and Interpretation $\ldots \ldots \ldots \ldots \ldots \ldots \ldots \ldots$

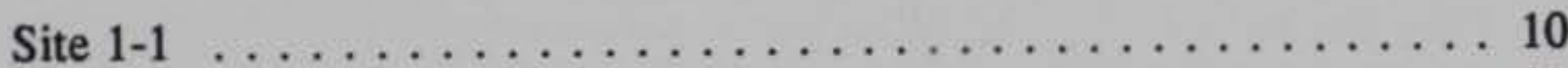

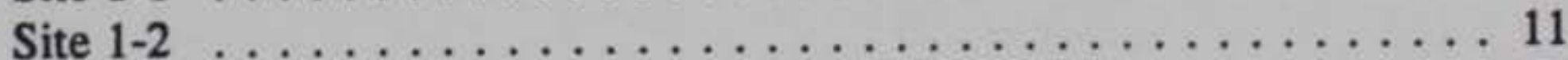

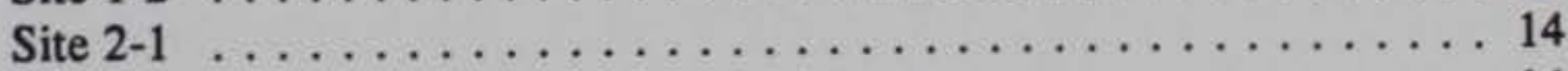

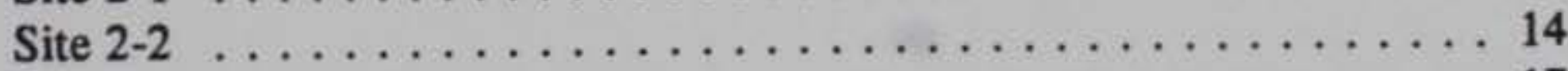

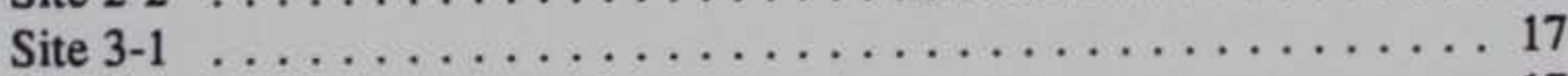

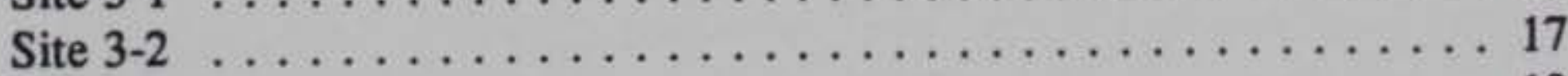

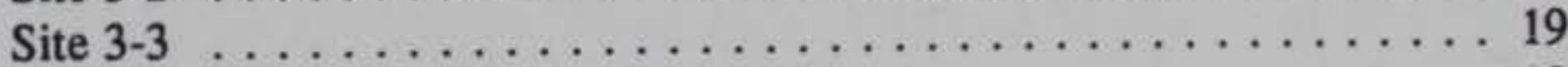

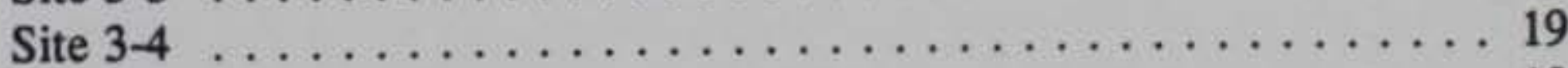

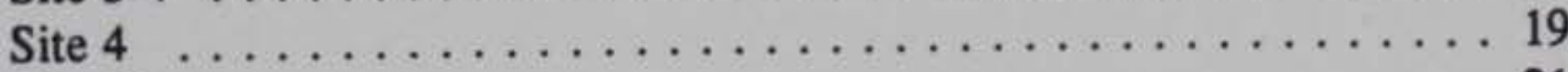

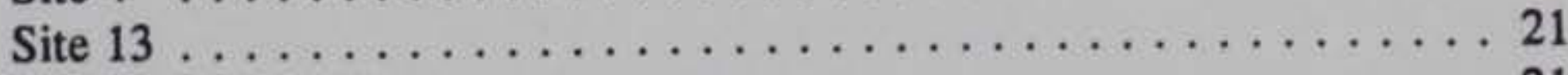

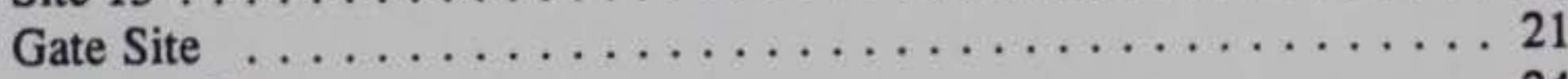

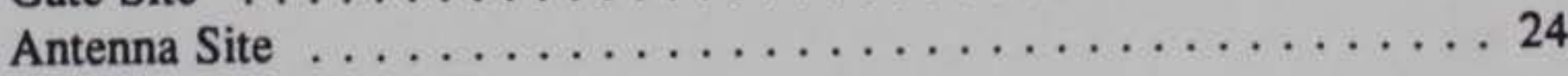


Army Reserve Site . . . . . . . . . . . . . . . . . 24

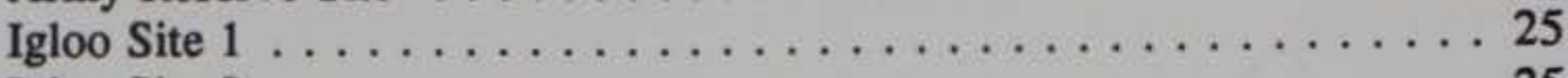

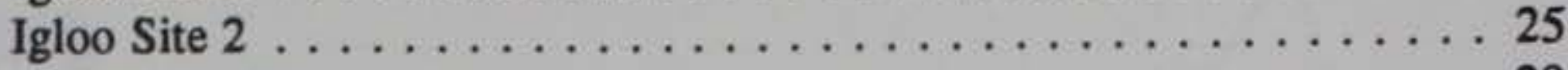

Refraction Site . . . . . . . . . . . . . . . . 29

5-Summary and Conclusions $\ldots \ldots \ldots \ldots \ldots \ldots \ldots$

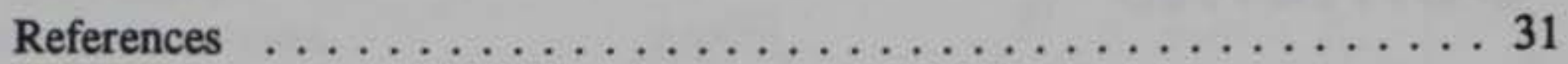

Figures 1-89 


\section{Preface}

A geophysical investigation was conducted at Fort Detrick, Maryland, by personnel of the Geotechnical Laboratory (GL), US Army Waterways Experiment Station (WES) during the periods 2 - 5 February and 24 March through 1 April 1993. The investigation was performed for the US Army Environmental Center (AEC), Aberdeen Proving Ground, Maryland. The AEC Project Engineer was Ms. Catherine Johnson and the AEC Project Geologist was Mr. Larry Nutter.

This report was prepared by Mr. José L. Llopis and Dr. Janet E. Simms, Earthquake Engineering and Geosciences Division (EEGD). The work was performed under the direct supervision of Mr. Joseph R. Curro, Jr., Chief, Engineering Geophysics Branch. The work was performed under the general supervision of Drs. A. G. Franklin, Chief, EEGD, and William F. Marcuson III, Director, GL. Field work and data analysis were performed by Mr. José L. Llopis and Dr. Janet E. Simms.

At the time of publication of this report, Director of WES was Dr. Robert W. Whalin. Commander was COL Leonard G. Hassell, EN. 


\section{Conversion Factors,}

Non-SI to SI Units of Measurement

Non-SI units of measurement used in this report can be converted to SI (metric) units as follows:

\begin{tabular}{||l|l|l||}
\hline Multiply & By & To Obtain \\
\hline \hline acres & 4046.873 & square meters \\
\hline feet & 0.3048 & meters \\
\hline miles (U.S. statute) & 1.609347 & kilometers \\
\hline
\end{tabular}




\section{Introduction}

\section{Background}

Fort Detrick is located within the city of Frederick, MD approximately 47 miles west of Baltimore, MD and 45 miles north of Washington, D.C (Figure 1). From its activation in 1943 until 1969, Fort Detrick served as the nation's center for military offensive and defensive biological research. In 1969 President Nixon ordered the termination of US research in offensive biological warfare. In 1972 Fort Detrick was transferred under the command of the Office of the Surgeon General, Department of the Army. Today the major mission of the US Army Garrison at Fort Detrick is to provide centralized Base Operations Support Services, required locally or directed by higher authority, to support the facilities and operations of those tenant units assigned or attached to Fort Detrick, US Army Garrison.

Fort Detrick is divided into areas A and B (Figure 2). Area A (Main Post) is approximately 797 acres in area and contains most of the US Army Garrison facilities and all of the Posț's major tenant activities. Area B is located about 0.5 miles west of the Main Post and contains approximately 399 acres. This area was used as a testing area until 1970 and a burial site from 1946 to at least 1977. Area B is presently used for livestock pasture.

A Records Research (R/R) study was conducted at Fort Detrick in October 1976 to estimate possible contamination at the installation by chemical, biological, and radiological material, to assess the possibility of contaminant migration beyond the boundaries, and to evaluate the requirements for a preliminary survey. The R/R study reports that burial sites within Area B contain chemi$\mathrm{cal}$, biological, radiological material and possibly unexploded ordnance (UXO's) (Department of the Army 1977).

Trichloroethylene (TCE), a suspected carcinogen, has recently been detected in water samples taken from several wells in Area B and in samples taken from water wells from private residences outside the boundaries of Area B. It is suspected that burial pits located within Area B are the source of the TCE. The main objective of an investigation, being managed by personnel of the US Army Environmental Center (AEC), is to determine whether burial pits located within Area B are the source of the TCE contamination. Because of poor or no record keeping standards in the past, only the general locations of the burial pits are known. 


\section{Objectives}

At the request of AEC, personnel of the US Army Waterways Experiment Station (WES) conducted a geophysical investigation at Fort Detrick during the periods 2 through 5 February and 24 March through 1 April 1993. The primary objective of the geophysical investigation was to delineate anomalies indicative of buried waste pits at several suspect sites within Area B (Figure 3). The study sites ranged from less than 1 acre to over 4 acres in area. Electromagnetic (EM), magnetic, and ground penetrating radar (GPR) methods were used to meet this objective. A secondary objective of this study was to confirm the location of a mapped fault that runs across Area B utilizing the seismic refraction method. 


\section{Area B Characteristics}

\section{Area Geology}

Area B is located in the geologic subprovince called the Frederick Valley, an area about 6 miles wide and 23 miles long, which is within the Piedmont physiographic province. The ground surface is characterized by broad undulating knobs and ridges and stream valleys that are deep and narrow. Cambrian limestone and Triassic shales and conglomerates form the principal rock types underlying this area. Dip of the rock strata is usually steep and at Area B is on the order of $30^{\circ}$ to $50^{\circ}$ (US Army Engineer District, Baltimore 1983).

\section{Site Geology}

The topography at the site is gentle and rather smooth, with elevations ranging between approximately 400 and $325 \mathrm{ft}$. MSL. In the central and northeast portions of the site are Triassic shales, mudstones, and limestone conglomerate, which are separated from Cambrian limestone by a large fault which runs from northwest to southeast and essentially through the center of the site. The limestones are medium to massively bedded and have been solutioned to a moderate degree in which solution channels and cavities are present. These solutioned zones are often partially or nearly completely filled with a red, highly plastic, low permeability clay (US Army Engineer District, Baltimore 1983). A geologic map of Area B is presented in Figure 4. Geologic cross sections through Area B are shown in Figure 5.

The Triassic red shale and mudstone are moderately hard and moderately jointed. The overburden is a low permeability red residual clay which ranges from about 5 to $20 \mathrm{ft}$ in thickness. The Triassic conglomerate is a fanglomerate which is consolidated coarse silty-clayey sandy matrix. The limestone conglomerate is soluble in mild acids, and is characterized by cavities and solution channels which are partially or completely clay filled. The Triassic shales and conglomerate are of the Newark group. The Upper Cambrian limestones are of the Frederick formation or the Rocky Springs Station member. The strike of the strata generally runs northeast to southwest and the dip is to the east-southeast about $30^{\circ}$ to $50^{\circ}$ (US Army Engineer District, Baltimore 1983). 


\section{Soils}

Five major soil types are found in Area B and are identified agriculturally as the Athol gravelly loam, Augusta gravelly loam, Hagerstown rocky loam, Lindside silt loam, and the Penn shaly loam. The Athol and Augusta gravelly loam occupy the major portion of the surface within Area B. The areal distribution of soils is shown in Figure 6. A description of the soils is presented in Table 1.

\begin{tabular}{||l|l||}
\hline \multicolumn{2}{||l||}{$\begin{array}{l}\text { Table 1 } \\
\text { Area B Soil Description }\end{array}$} \\
\hline \hline Soil Series & Description \\
\hline Athol gravelly loam & $\begin{array}{l}\text { Gravelly or rocky soils deep and well drained. Developed from } \\
\text { weathered limestone, red shale and sandstone. Yellow-red to } \\
\text { reddish brown, hard when dry, slightly plastic when wet. Some } \\
\text { silt and clay occurring with depth. }\end{array}$ \\
\hline $\begin{array}{l}\text { Augusta gravelly } \\
\text { loam }\end{array}$ & $\begin{array}{l}\text { Gravelly or rocky soils, moderately well drained, moderately deep. } \\
\text { Developed from colluvial and alluvial gravel and stony debris of } \\
\text { quartzite and sandstone. Olive brown, hard when dry, sticky and } \\
\text { plastic when wet. found on alluvial terraces and low deposits of } \\
\text { colluvial material. }\end{array}$ \\
\hline $\begin{array}{l}\text { Hagerstown rocky } \\
\text { loam }\end{array}$ & $\begin{array}{l}\text { Deep, strongly developed well drained, derived from limestone. } \\
\text { Brown to yellow red. Hard when dry, very sticky when wet. } \\
\text { Contains many outcrops of limestone in form of ledges. Scattered } \\
\text { rock fragments are present on the surface. }\end{array}$ \\
\hline Penn shaly loam & $\begin{array}{l}\text { Moderately well drained soil of floodplains and upland depressions. } \\
\text { Developed from fine material washed from Duffield, Hagerstown, } \\
\text { and Frankstown series. Dark gray to olive brown in color. Lower } \\
\text { strata of clay is light to greenish blue. }\end{array}$ \\
\hline $\begin{array}{l}\text { Well drained, moderately to very shallow, developed from purple to } \\
\text { dark red shale and sandstone. Reddish brown silty to clayey loam } \\
\text { with partly decomposed shale. }\end{array}$ \\
\hline \hline
\end{tabular}

(Source: Department of the Army 1977) 


\section{Geophysical Test Principles and Field Procedures}

\section{Geophysical Test Principles}

\section{Electromagnetic surveys}

The EM technique is used to measure differences in terrain conductivity. Like electrical resistivity, conductivity is affected by differences in soil porosity, water content, chemical nature of the ground water and soil, and the physical nature of the soil. In fact, for a homogeneous earth, the true conductivity is the reciprocal of the true resistivity. Some advantages of using the EM over the electrical resistivity technique are (a) less sensitivity to localized resistivity inhomogeneities, (b) no direct contact with the ground required, thus no current injection problems, (c) smaller crew size required, and (d) rapid measurements (McNeil 1980).

The EM equipment used in this survey consists of a transmitter and receiver coil set a fixed distance apart. The transmitter coil is energized with an alternating current at an audio frequency ( $\mathrm{Khz}$ range) to produce a time-varying magnetic field which in turn induces small eddy currents in the ground. These currents then generate secondary magnetic fields which are sensed together with the primary field by the receiver coil. The units of conductivity are millimhos per meter $(\mathrm{mmho} / \mathrm{m})$ or, in the SI system milliSiemens per meter $(\mathrm{mS} / \mathrm{m})$. The EM data are then presented in profile plots or as isoconductivity contours if data are obtained in a grid form. A more thorough discussion on EM theory and field procedures is given by Butler (1986), Telford et al. (1973) and Nabighian (1988).

There are two components of the induced magnetic field measured by the EM equipment. The first is the quadrature phase component, which gives the ground conductivity measurement. The second is the in-phase component, which is used primarily for calibration purposes. However, the in-phase component is significantly more sensitive to large metallic objects and hence very useful when looking for buried metal containers (Geonics Limited 1984). When measuring the in-phase component, the true zero level is not known since the reference level is arbitrarily set by the operator. Therefore, 
measurements collected in this mode are relative to a reference level and have arbitrary units of parts per thousand (ppt).

A Geonics model EM-31 ground conductivity meter was used to survey the sites. The EM-31 has an intercoil spacing of $12 \mathrm{ft}$ and an effective depth of exploration of about $20 \mathrm{ft}$ (Geonics Limited 1984). The EM-31 meter reading is a weighted average of the earth's conductivity as a function of depth. A thorough investigation to a depth of $12 \mathrm{ft}$ is usually possible, but below that depth the effect of conductive anomalies becomes more difficult to distinguish. The EM-31, when carried at a usual height of approximately $3 \mathrm{ft}$, is most sensitive to features at a depth of about $1 \mathrm{ft}$. Half of the instrument's readings result from features shallower than about $9 \mathrm{ft}$, and the remaining half from below that depth (Bevan 1983). Figure 7 more clearly illustrates the effect of depth on instrument sensitivity with the dashed line depicting the sensitivity of the instrument to objects between it and the ground surface. The instrument can be operated in both a horizontal and vertical dipole orientation (Figure 8) with correspondingly different effective depths of exploration. The instrument is normally operated with the dipoles vertically oriented (coils oriented horizontally and co-planar) which gives the maximum depth of penetration. The instrument can be operated in a continuous or a discrete mode.

\section{Magnetic surveys}

The magnetic method of surveying is based on the ability to measure local disturbances of the earth's magnetic field. Magnetic anomalies are caused by two different types of magnetism: induced and remanent magnetization. Remanent magnetization is a permanent magnetic moment per unit volume whereas induced magnetization is temporary magnetization that disappears if the material is removed from a magnetic field. Generally, the induced magnetization is parallel with and proportional to the inducing field (Barrows and Rocchio 1990). The remanent magnetism of a material depends on the thermal and magnetic history of the body and is independent of the field in which it is measured (Breiner 1973).

An EDA OMNI IV proton-precession magnetometer was used to measure the total field intensity of the local magnetic field. The magnetic unit of measurement is the nanotesla (nT), equivalent to one gamma. The local magnetic field is the vector sum of the field of the local magnetized materials (local disturbance) and the ambient (undisturbed) magnetic field. Figure 9 shows the ambient earth's field as $50,000 \mathrm{nT}$ with a local disturbance of $10 \mathrm{nT}$. Figure 9 shows that the quantity measured with the magnetometer is the resultant total field with a value of $50,006 \mathrm{nT}$.

The magnetometer was also used with dual sensors at selected sites, allowing the vertical gradient of the total magnetic field to be measured. The gradient is taken by measuring the total field at a survey point using two sensors which are fixed a small vertical distance apart. The difference in values between the two sensors divided by their separation approximates the gradient measured at the midpoint of the sensor spacing. Two advantages of using the 
magnetic gradient are that 1 . the regional magnetic gradient is filtered out thus local anomalies are better defined and 2. since the two readings are taken simultaneously magnetic storm effects and diurnal magnetic variations are essentially removed (Breiner 1973). The magnetometer used in this survey has an absolute accuracy of approximately \pm 1 gamma. For reference, the earth's magnetic field varies from approximately 60,000 gammas at the poles to 30,000 gammas at the equator (the nominal field strength at Ft. Detrick is 54,000 gammas).

A magnetic anomaly represents a local disturbance in the earth's magnetic field which arises from a localized change in magnetization, or magnetization contrast. The observed anomaly expresses the net effect of the induced and remanent magnetization and the earth's ambient magnetic field. Depth of detection of a localized subsurface feature depends on its mass, magnetization, shape and orientation, and state of deterioration.

\section{Ground penetrating radar surveys}

Ground penetrating radar (GPR) is a geophysical subsurface exploration method using high frequency EM waves. The GPR system consists of a transmitting and a receiving antenna. The transmitting antenna transmits an EM signal into the ground and is reflected by materials having contrasting electrical properties back to the receiving antenna. These signals are then amplified, processed and recorded to provide a continuous profile of the subsurface.

The transmitted EM waves respond to changes in soil and rock conditions having sufficiently different electrical properties such as those caused by clay content, soil moisture or ground water, water salinity, cementation, man-made objects, voids, etc. The depth of exploration is determined by the electrical properties of the soil or rock as well as by the power of the transmitting antenna. The primary disadvantage to GPR is its extremely site specific applicability; the presence of high-clay content soils in the shallow subsurface will generally defeat the application of GPR (Olhoeft 1984). High water contents in the shallow subsurface and shallow water tables can also limit the applicability of GPR at some sites. A general rule is that GPR should not be applied to projects in which the mapping objective is greater than $50 \mathrm{ft}$ in depth. For shallow mapping applications at sites with low clay content soils, GPR will generally have the best vertical and horizontal resolution of any geophysical method (Butler and Llopis 1990).

A Geophysical Survey Systems, Inc. SIR System-8 radar with a $300 \mathrm{MHz}$ antenna was used to conduct the GPR surveys. A graphic recorder was used with the SIR System-8. The graphic recorder accepts the analog signal from the receiver and produces a continuous, permanent chart on electro-sensitive paper. By recording a vertical intensity modulated scan for every few inches of antenna travel, a continuous profile is developed showing reflections from subsurface strata and anomalies within the strata. Figure 10 illustrates the GPR survey concept. 


\section{Seismic refraction surveys}

The seismic refraction method utilizes the fact that the compression-wave (P-wave) velocity of a material is dependent on its elastic properties. The method is based on the assumption that materials are locally homogeneous and isotropic and that the P-wave velocity of the subsurface materials increase monotonically with depth. In the seismic refraction method, a seismic disturbance is usually produced by means of explosives or by striking a metal plate on the ground with a sledgehammer. The location of the seismic disturbance is considered to be a point source and the disturbance is transmitted through the ground as a series of waves. Geophones (velocity transducers) are implanted into the ground surface and laid along a straight line spaced at regular intervals. The length of the survey line depends on the required depth of investigation; a common rule of thumb is that the length of the line should be from three to four times the depth of interest. The function of the geophones is to detect the arrival of the P-wave. A geophone consists of a wire coil that moves relative to a magnet, thus generating an electrical signal. These signals are then transmitted via a cable to a seismograph where they are amplified and the time of arrival of the P-wave at each location determined.

The seismic refraction data are interpreted by plotting the P-wave arrival time versus geophone distance from the seismic source. Straight line segments are drawn through the plotted points. Points falling on or near the same straight line segment are interpreted to correspond to the same subsurface layer. The inverse slopes of the line segments drawn through the data points represent the P-wave velocities of the layer. Depths to interfaces beneath each shot point are calculated by making use of Snell's law. The analysis of seismic refraction data for cases with more than two layers, dipping layers, and more complicated geological structures are described in Redpath 1973, Palmer 1980, Department of the Army 1979, and other standard geophysical references.

\section{Field Procedures}

Detailed surveys were conducted by establishing rectangular-shaped grids at the sites to encompass the area of interest. The grid stations at the sites were marked at constant intervals by implanting polyvinyl chloride (PVC) stakes into the ground. PVC stakes were used to prevent any possible interference with the geophysical tests conducted at the sites.

The EM-31 data were taken in both the quadrature phase (conductivity) and in-phase mode at each measurement station. Measurements were recorded on a digital data logger and transferred to a portable field computer at the conclusion of the survey.

The "tie-line" method for correcting diurnal drift was used when total magnetic field surveys were conducted. Using this method a reading is taken by the operator at a known and identified base reference point and it is stored in 
the magnetometer's memory. A sequence of tie-points, usually taken on the baseline which cuts through the grid, are quickly read (in the shortest amount of time possible) and stored in memory. The operator then doubles back to the base reference point and takes another reading. This closes the loop and establishes the tie line in the memory of the magnetometer. For proper diurnal corrections of the these tie-points, built-in software in the magnetometer calculates by linear interpolation the drift in the earths's magnetic field with respect to the time each was taken.

In distributing the drift in the earth's magnetic field and applying it to the times the tie-point readings were taken, truly accurate field results are calculated for each of the tie points. During the survey, each time the operator crosses on a tie-point and a reading taken there, the reading is flagged for calculating the diurnal drift. At the end of survey day the magnetometer data were transferred to a portable field computer.

At those sites where magnetic gradient surveys were conducted, gradient data was collected in conjunction with total field measurements. The data were also stored in the magnetometer's memory and transferred to a portable computer at the end of the survey.

The radar antenna was hand-towed along each survey line at a slow walking rate (approximately 1 to 2 miles per hour) while the control unit and graphic recorder were operated from a motorized vehicle. Station positions were established on the radar records by electronically impressing dashed, vertical reference lines on the graphic records as the antenna passed each marked location.

A sledgehammer striking a steel plate was used as the energy source for the seismic refraction surveys. Forward and reverse traverses were conducted for each refraction line in order to obtain true P-wave velocities of the subsurface materials. 


\section{Test Results and Interpretation}

In deciding what constitutes a significant anomaly for a particular site several factors must be weighed. Anomaly detection is limited by instrument accuracy and local "noise" or variations in the measurements caused by factors not associated with the anomalies of interest such as fences, power lines, metal buildings, etc. (cultural noise). For the anomaly to be significant, the measurement due to the anomaly must have a response greater than that due to the interfering cultural noise. Since the anomaly amplitude, spatial extent, and wavelength are the keys to detection, the size and depth of the feature causing the anomaly are important factors in determining detectability and resolution. The intensity of the anomaly is also a function of the degree of contrast in material properties between the anomaly and the surrounding material.

Figures were prepared showing the contoured values of the EM-31 conductivity, EM-31 in-phase component, total magnetic field, and magnetic gradient data collected at each of the test sites. Based upon the test method employed, noise conditions at the sites and the assumption that the target objects are relatively shallow (less than $10 \mathrm{ft}$ ), anomalous areas considered as significant are indicated in these figures by bold lines. No contour map is presented for the GPR data since GPR data cannot be contoured. The location, type, and an interpretation of the anomalies for the test sites indicated in these figures were tabulated and are presented in Tables 2 through 16.

A brief description of each test site including the grid layout, tests conducted and pertinent cultural and surface features are given below. Also discussed below are the major anomalies interpreted at each site.

\section{Site 1-1}

Site 1-1 encompasses an area reportedly containing several disposal trenches (Department of the Army 1977). Surface features found at the site including the location of Wells 16, 17 and 18 are shown in the site map (Figure 11). The results of the EM-31 conductivity, in-phase and total magnetic field surveys are presented in Figures 12 through 14, respectively. All survey lines were oriented in a northwest-southeast direction or when referenced to the site 
map in a right-left direction. The EM-31 data were collected on a $10-\mathrm{ft}$ grid interval over the southern portion of the site $(00 \mathrm{~N}$ to $300 \mathrm{~N})$. In the areas between $300 \mathrm{~N}$ to $480 \mathrm{~N}$ and between $580 \mathrm{~N}$ to $600 \mathrm{~N}$ EM data was collected using a 10-ft station interval along survey lines spaced $20 \mathrm{ft}$ apart. In the area between $480 \mathrm{~N}$ to $580 \mathrm{~N}$ the EM data was collected using a 10 -ft grid spacing. The magnetic data were collected over the entire site using a 10-ft grid spacing. The GPR survey was conducted inside a rectangular portion of Site 1-1 whose corners are defined by stations $(300 \mathrm{~N}, 00 \mathrm{E}),(300 \mathrm{~N}, 240 \mathrm{E})$, $(600 \mathrm{~N}, 240 \mathrm{E})$, and $(600 \mathrm{~N}, 00 \mathrm{E})$.

The EM-31 and magnetic survey results indicate a large anomalous region bounded by stations $(200 \mathrm{~N}, 00 \mathrm{E}),(300 \mathrm{~N}, 240 \mathrm{E}),(500 \mathrm{~N}, 240 \mathrm{E}),(425 \mathrm{~N}, 00 \mathrm{E})$. Within this area there are numerous anomalies which have a preferred northnortheast trending orientation. The anomalies are lined up in such a manner as suggesting the possibility of buried trenches in this area. Two other anomalies are interpreted in the vicinity of $(550 \mathrm{~N}, 160 \mathrm{E})$ and $(550 \mathrm{~N}, 60 \mathrm{E})$. These anomalies may be caused by a combination of buried non-ferrous and/or ferrous objects. Another large anomaly occurs in the upper right-hand portion of the site near $(50 \mathrm{~N}, 200 \mathrm{E})$. This anomaly may be caused by a change in soil type, buried non-ferrous and/or ferrous material.

The GPR survey lines were spaced $20 \mathrm{ft}$ apart and a continuous record of the subsurface obtained for each survey line. A typical GPR record collected at Site 1-1 is shown in Figure 15. The GPR record indicates areas of soil disturbance and hyperbolic signatures indicative of small localized reflectors. The GPR results for Site 1-1 are presented in Figure 16. The solid black lines shown in Figure 16 indicate areas where GPR results were considered to be caused by previous soil excavation or soil disturbance whereas the "X's" indicate discrete GPR anomalies. The GPR results indicate that the majority of the site seems to have been disturbed since most of the records indicated a lack of continuous subsurface strata. Also, the GPR recorded very few discrete reflectors. The tabulated interpreted anomalies for Site 1-1 are presented in Table 2. The GPR was employed only at Site 1-1 because of time limitations.

\section{Site 1-2}

The location of Site 1-2 is shown in Figure 3. The site map for Site 1-2 is presented in Figure 17. The majority of the site was located on a fill area. The fill extended to the northern edge of the site where large chunks of concrete with rebar and other construction debris, some of it metallic, were observed. EM-31 conductivity, in-phase, total magnetic field and magnetic gradient survey results are presented in Figures 18 through 21 , respectively. The data were collected on a $20 \mathrm{ft}$ grid interval. The tabulated results for Site 1-2 are shown in Table 3.

The major anomaly at Site 1-2 occurred in the lower left hand portion of the site, an area inside $(00 \mathrm{E}, 75 \mathrm{~N}),(150 \mathrm{E}, 125 \mathrm{~N}),(150 \mathrm{E}, 200 \mathrm{~N}),(75 \mathrm{E}, 250 \mathrm{~N})$, 
Table 2

Geophysical Anomaly Interpretation, Site 1-1

\begin{tabular}{|c|c|c|c|c|c|}
\hline \multirow{2}{*}{ Anomaly Location } & \multicolumn{2}{|c|}{ EM-31 } & \multirow{2}{*}{$\begin{array}{l}\text { Mag } \\
T\end{array}$} & \multirow[b]{2}{*}{ GPR } & \multirow{2}{*}{ Anomaly Description and Interpretation } \\
\hline & c & $\mathbf{I}$ & & & \\
\hline $\begin{array}{l}\text { Area bounded by stations } \\
(200 \mathrm{~N}, 00 \mathrm{E}),(300 \mathrm{~N}, 240 \mathrm{E}) \text {, } \\
(500 \mathrm{~N}, 240 \mathrm{E}),(425 \mathrm{~N}, 00 \mathrm{E})\end{array}$ & $\mathbf{x}$ & $\mathbf{x}$ & $\mathbf{x}$ & $\mathbf{x}$ & $\begin{array}{l}\text { High and low magnetic, EM- } 31 \text { conductivity and in-phase } \\
\text { readings. Numerous anomalies indicated in this area. } \\
\text { Anomalies have a preferred N-NE orientation which may } \\
\text { be related to buried trenches. Anomalies may be caused } \\
\text { by buried ferrous objects or a combination of buried fer- } \\
\text { rous objects, other buried metallic debris, and disturbed } \\
\text { soil. }\end{array}$ \\
\hline (OON, 100E)-(225N, 100E) & & & $x$ & & $\begin{array}{l}\text { High magnetic anomaly probably caused by buried ferrous } \\
\text { material. Anomaly may be too deep to be detected by EM } \\
\text { methods. The anomaly is elongated and approximately } 25 \\
\mathrm{ft} \text { wido. }\end{array}$ \\
\hline (550N, 160E) & $x$ & $x$ & $x$ & $\mathbf{x}$ & $\begin{array}{l}\text { Cluster of anomalies. Anomalies may be caused by buried } \\
\text { ferrous objects or a combination of buried ferrous objects, } \\
\text { metallic debris or disturbed soil. }\end{array}$ \\
\hline (55ON,60E) & & $x$ & $x$ & $x$ & $\begin{array}{l}\text { A group of small anomalies. Anomalies may be due to the } \\
\text { presence of buried ferrous debris. }\end{array}$ \\
\hline$(160 N, 40 E)$ & x? & $\mathbf{x}$ & $x$ & & $\begin{array}{l}\text { This area is a cluster of small magnetic and in-phase } \\
\text { anomalies. A very weak conductivity anomaly is also } \\
\text { found here. Anomaly may be caused by buried ferrous } \\
\text { and other metallic debris. }\end{array}$ \\
\hline (50N, 200E) & $x$ & $x$ & $x$ & & $\begin{array}{l}\text { High EM- } 31 \text { conductivity and in-phase readings. The } \\
\text { conductivity anomaly covers a large area whereas the in- } \\
\text { phase and magnetometer anomalies are more localized. } \\
\text { The conductivity anomaly may be due to a change in soil } \\
\text { type. There may be buried ferrous material in the area } \\
\text { where the conductivity, in-phase, and magnetometer } \\
\text { anomalies overlap. }\end{array}$ \\
\hline
\end{tabular}

Note:

$$
\begin{aligned}
C & =E M \text { conductivity } \\
I & =E M \text { in-phase } \\
T & =\text { Total magnetic field } \\
G P R & =\text { Ground penetrating radar }
\end{aligned}
$$




\begin{tabular}{|c|c|c|c|c|c|}
\hline \multicolumn{6}{|c|}{$\begin{array}{l}\text { Table } 3 \\
\text { Geophysical Anomaly Interpretation, Site 1-2 }\end{array}$} \\
\hline \multirow{2}{*}{ Anomaly Location } & \multicolumn{2}{|c|}{ EM-31 } & \multicolumn{2}{|c|}{ Mag } & \multirow{2}{*}{ Anomaly Description and Interpretation } \\
\hline & c & 1 & $\mathbf{T}$ & 6 & \\
\hline $\begin{array}{l}\text { Area inside (OOE,75N), (150E,125N), } \\
(150 E, 200 N),(75 E, 25 O N) \text { and } \\
(O O E, 200 N)\end{array}$ & $x$ & $x$ & $\mathbf{x}$ & $x$ & $\begin{array}{l}\text { Large anomalous feature situated on grassy part of the site. } \\
\text { Conductivity in this area is very high. The in-phase and } \\
\text { magnetic data show many high-low signatures. Anomaly } \\
\text { may be caused by buried non-ferrous and/or ferrous debris. }\end{array}$ \\
\hline (225E, 125N) & $x$ & $x$ & & & This anomaly may be caused by buried non-ferrous debris. \\
\hline (370E,120N) & $x$ & $x$ & & & $\begin{array}{l}\text { This anomaly occurs near edge of the rubble pile. High } \\
\text { conductivity anomaly indicated. This anomaly may be } \\
\text { caused by buried ferrous and non-ferrous debris. }\end{array}$ \\
\hline (460E,7ON) & $x$ & & $\mathbf{x}$ & $x$ & $\begin{array}{l}\text { Anomaly is located in grassy area of the site. Anomaly } \\
\text { probably caused by buried ferrous debris. }\end{array}$ \\
\hline$(460 E, 200 N)$ & & & $\mathbf{x}$ & $\mathbf{x}$ & $\begin{array}{l}\text { Anomaly located along edge of rubble mound and probably } \\
\text { caused by ferrous debris in the rubble fill. }\end{array}$ \\
\hline (425E, 15ON) & & $\mathbf{x}$ & & & $\begin{array}{l}\text { In-phase anomaly probably caused by non-ferrous metallic } \\
\text { object or small ferrous object. }\end{array}$ \\
\hline $\begin{array}{l}\text { Area inside (300E, 260N), } \\
(400 \mathrm{E}, 300 \mathrm{~N}),(400 \mathrm{E}, 380 \mathrm{~N}) \\
(300 \mathrm{E}, 380 \mathrm{~N})\end{array}$ & $x$ & $x$ & $\mathbf{x}$ & & Anomaly probably caused by buried ferrous debris. \\
\hline (325E, 150N) & & & $\mathbf{x}$ & $\mathrm{x}$ & Anomalies probably caused by ferrous object. \\
\hline
\end{tabular}

Note:
$\mathrm{C}=\mathrm{EM}$ conductivity
$I=E M$ in-phase
$T=$ Total magnetic field
$G=$ Magnetic gradient 
and $(00 \mathrm{E}, 200 \mathrm{~N})$. Another significant anomaly is centered about $(460 \mathrm{E}, 70 \mathrm{~N})$. These two anomalies occur in grassy areas of the site and are not considered as being part of the nearby debris pile. The other anomalies found at the site are probably related to buried debris.

\section{Site 2-1}

Site 2-1 is an area suspected of having a burial pit within its boundaries (Department of the Army 1977). The site boundaries, locations of Wells 25 and 37 and a metal sign are shown in Figure 22. Wells 25 and 37 mark the approximate southeast and northeast corners of the site, respectively. The data were collected on a $10 \mathrm{ft}$ grid interval. EM-31 conductivity, in-phase, and total magnetic field survey results are presented in Figures 23 through 25, respectively. The interpreted anomalies are shown in Table 4.

A significant linear anomaly or series of anomalies located between $(120 \mathrm{~N}, 75 \mathrm{E})$ and $(90 \mathrm{~N}, 240 \mathrm{~N})$ was indicated by all of the surveys. This anomaly is probably caused by a buried ferrous object(s). Another significant anomaly is located in the lower right-hand portion of the site near $(70 \mathrm{~N}, 10 \mathrm{E})$. This anomalous area was detected by all three survey methods and it is considered to be caused by buried ferrous material. The alternating cigar-shaped, north-south trending, contours in Figure 25 are not considered to be indicative of anomalous conditions. It is presumed that these elongated features may have been caused by the collection of a spurious data point at a tie line position.

\section{Site 2-2}

Site 2-2 contains numerous north-south trending depressions along the western portion of the site as shown in the site map (Figure 26). The depressions are suspected of denoting the locations of old burial trenches. EM-31 conductivity, in-phase, total magnetic field, and magnetic gradient surveys were conducted at this site and are presented in Figures 27 through 30, respectively. The survey lines were oriented in an east-west direction and readings taken using a $10-\mathrm{ft}$ grid interval. A description and interpretation of the anomalies is presented in Table 5.

Numerous anomalies were interpreted in the western portion of the site and their locations coincide with the locations of the shallow depressions. It is likely that the depressions indicate the boundaries of old burial trenches since the location of the interpreted anomalies and the depressions correspond so closely. 


\section{Table 4}

Geophysical Anomaly Interpretation, Site 2-1

\begin{tabular}{|c|c|c|c|c|}
\hline \multirow{2}{*}{ Anomaly Location } & \multicolumn{2}{|c|}{ EM-31 } & \multirow{2}{*}{$\frac{\text { Mag }}{T}$} & \multirow{2}{*}{ Anomaly Description and Interprotation } \\
\hline & c & $\mathbf{1}$ & & \\
\hline (120N,75E)-(9ON,240E) & $x$ & $x$ & $x$ & $\begin{array}{l}\text { Elongated anomaly between these two stations. Anomaly is } \\
\text { approximately } 5-10 \mathrm{ft} \text { wide. Magnetometer data show high } \\
\text { and low "bull's-eye" type anomalies. Conductivity data gener- } \\
\text { ally show high-low signature proceeding south to north. The } \\
\text { in-phase data show a low-high-low signature as one proceeds } \\
\text { in a south-north direction. Anomaly may be caused by buried } \\
\text { non-ferrous and/or ferrous debris. }\end{array}$ \\
\hline (14ON,OOE)-(12ON,4OE) & $x$ & $\mathrm{x}$ & $\mathbf{x}$ & $\begin{array}{l}\text { Magnetic and conductivity high anomaly indicated. The in- } \\
\text { phase shows a low-high-low anomaly in a south-north direc- } \\
\text { tion. This anomaly may be caused by buried non-ferrous } \\
\text { and/or ferrous debris. This anomalous area may be an exten- } \\
\text { sion of the linear anomaly described above. }\end{array}$ \\
\hline (7ON, 1OE) & $x$ & $x$ & $x$ & $\begin{array}{l}\text { Cluster of anomalies. Anomalies may be caused by buried } \\
\text { ferrous objects or a combination of buried ferrous objects, } \\
\text { metallic debris or disturbed soil. }\end{array}$ \\
\hline
\end{tabular}




\begin{tabular}{|c|c|c|c|c|c|}
\hline \multicolumn{6}{|c|}{$\begin{array}{l}\text { Table } 5 \\
\text { Geophysical Anomaly Interpretation, Site 2-2 }\end{array}$} \\
\hline \multirow[b]{2}{*}{ Anomaly Location } & \multicolumn{2}{|c|}{ EM-31 } & \multicolumn{2}{|c|}{ Mag } & \multirow[b]{2}{*}{ Anomaly Description and Interprotation } \\
\hline & c & 1 & $T$ & $\mathbf{G}$ & \\
\hline $\begin{array}{l}\text { Area inside }(00 \mathrm{~N}, 160 \mathrm{~W}),(00 \mathrm{~N}, 240 \mathrm{~W}) \text {. } \\
(140 \mathrm{~N}, 240 \mathrm{~W}),(140 \mathrm{~N}, 160 \mathrm{~W})\end{array}$ & $x$ & $x$ & $\mathbf{x}$ & $\mathbf{x}$ & $\begin{array}{l}\text { Large anomalous area in the upper left-hand portion of the } \\
\text { site. Conductivity anomaly covers most of this area. Local- } \\
\text { ized in-phase, magnetic total field and gradient anomalies } \\
\text { are found in this area. This area is characterized by north- } \\
\text { south trending depressions. The anomalies may be caused } \\
\text { by non-ferrous and/or ferrous debris buried in trenches. }\end{array}$ \\
\hline (170N,230W) & $\mathbf{x}$ & $x$ & $x$ & $x$ & $\begin{array}{l}\text { Small anomalous areas. This anomaly may be caused by } \\
\text { buried non-ferrous and/or ferrous debris. }\end{array}$ \\
\hline $\begin{array}{l}\text { Area inside }(240 \mathrm{~N}, 220 \mathrm{~W}) \\
(240 \mathrm{~N}, 200 \mathrm{~W}),(300 \mathrm{~N}, 240 \mathrm{~W}) \\
(300 \mathrm{~N}, 220 \mathrm{~W})\end{array}$ & $x$ & $x$ & $x$ & $x$ & $\begin{array}{l}\text { Anomalous area near depressions. This anomaly may be } \\
\text { caused by buried non-ferrous and/or ferrous debris. }\end{array}$ \\
\hline (230N, 170W) & $x$ & $x$ & $\mathrm{x}$ & $x$ & $\begin{array}{l}\text { This anomaly is in line with a ground depression. This ano- } \\
\text { maly may be caused by buried ferrous and/or non-ferrous } \\
\text { debris. }\end{array}$ \\
\hline
\end{tabular}


The region bounded by Site 3, Section 1 is reportedly an area which at one time was used as a landfill area (Department of the Army 1977). Figure 31 depicts the site boundaries, the location of Well 20 , cavities in the ground, and the general topography. The site slopes to the south and the bottom righthand portion of the site is relatively level. The EM-31 conductivity, in-phase, and total magnetic field survey results are presented in Figures 32 through 34, respectively. The data were collected at $10 \mathrm{ft}$ intervals along northwest-southeast trending survey lines, with survey lines spaced $20 \mathrm{ft}$ apart. An anomaly description and interpretation is presented in Table 6. In general, the western

In general, the western part of the site is relatively anomaly free. However, anomalies were interpreted from the conductivity, in-phase, and magnetic surveys for the eastern portion of the site. The anomalous area is bounded inside stations $(00 \mathrm{~W}, 30 \mathrm{~N}),(100 \mathrm{~W}, 30 \mathrm{~N}),(150 \mathrm{~W}, 60 \mathrm{~N}),(150 \mathrm{~W}, 140 \mathrm{~N})$, and $(00 \mathrm{~W}, 200 \mathrm{~N})$. This area is considered to contain large quantities of buried ferrous or a combination of ferrous and non-ferrous debris. A second anomaly which occurs at $(90 \mathrm{~W}, 00 \mathrm{~N})$ is caused by the steel casing around Well 20.

\section{Site 3-2}

The site map for Site 3-2 is shown in Figure 35. This site contains an area reported to have been previously used for dumping material (Department of the Army 1977). Metallic debris (plates, pipes, pipe flanges, etc.) were observed scattered over the ground surface. Partially buried rusted barrels and other buried metallic material were observed through $2-\mathrm{ft}$ wide voids in the ground. The site includes a soil bank that slopes down towards the south from the gravel road. The data were collected at $10 \mathrm{ft}$ intervals along the survey lines, with survey lines spaced $20 \mathrm{ft}$ apart. The survey lines were oriented in an east-west direction. EM-31 conductivity, in-phase and total magnetic field survey results are presented in Figures 36 through 38, respectively. A description and interpretation of the anomalies is presented in Table 7.

The EM-31 conductivity, in-phase and total magnetic field data indicate a large anomalous area bounded by stations $(150 \mathrm{~W}, 00 \mathrm{~N}),(300 \mathrm{~W}, 60 \mathrm{~N})$, $(300 \mathrm{~W}, 240 \mathrm{~N}),(00 \mathrm{~W}, 240 \mathrm{~N})$ and $(00 \mathrm{~W}, 00 \mathrm{~N})$. As mentioned above this area slopes towards the south and it is possible that waste was dumped from the gravel road unto this area and later covered with soil. No linear anomalies were interpreted which would indicate the presence of burial trenches. The zone bounded by approximate stations $(180 \mathrm{~W}, 240 \mathrm{~N}),(225 \mathrm{~W}, 125 \mathrm{~N})$, $(260 \mathrm{~W}, 240 \mathrm{~N})$, and $(260 \mathrm{~W}, 80 \mathrm{~N})$ does not indicate significant anomalies. It is possible that this area is relatively free of debris. The level portion of the site does not indicate any anomalies with the exception of a weak anomalous area located at $(220 \mathrm{~W}, 00 \mathrm{~N})$. 


\section{Table 6}

Geophysical Anomaly Interpretation, Site 3-1

\begin{tabular}{|c|c|c|c|c|}
\hline \multirow{2}{*}{ Anomaly Location } & \multicolumn{2}{|c|}{ EM-31 } & \multirow{2}{*}{$\begin{array}{l}\text { Mag } \\
\mathbf{T}\end{array}$} & \multirow{2}{*}{ Anomaly Description and Interpratation } \\
\hline & C & 1 & & \\
\hline $\begin{array}{l}\text { Area bounded by stations } \\
(00 \mathrm{~W}, 30 \mathrm{~N}),(100 \mathrm{~W}, 30 \mathrm{~N}) \text {, } \\
(150 \mathrm{~W}, 60 \mathrm{~N}),(150 \mathrm{~W}, 140 \mathrm{~N}) \text {, } \\
(00 \mathrm{~W}, 200 \mathrm{~N})\end{array}$ & $\mathbf{x}$ & $\mathrm{x}$ & $\mathbf{x}$ & $\begin{array}{l}\text { High and low magnetic, conductivity and in-phase readings. } \\
\text { The large number of closed contour targats indicate the pres- } \\
\text { ence of numerous anomalies in this area. Anomalies may be } \\
\text { caused by buried ferrous objects or a combination of buried } \\
\text { ferrous objects, other buried metallic debris, and disturbed soil. }\end{array}$ \\
\hline (9OW,OON) & $x$ & $x$ & $\mathbf{x}$ & Anomaly caused by presence of Well 20. \\
\hline
\end{tabular}

Table 7

Geophysical Anomaly Interpretation, Site 3-2

\begin{tabular}{|c|c|c|c|c|}
\hline \multirow{2}{*}{ Anomaly Location } & \multicolumn{2}{|c|}{ EM-31 } & \multirow{2}{*}{$\frac{\text { Mag }}{T}$} & \multirow{2}{*}{ Anomaly Description and Interpretation } \\
\hline & c & 1 & & \\
\hline $\begin{array}{l}\text { Area bounded by stations } \\
(150 \mathrm{~W}, 00 \mathrm{~N}),(300 \mathrm{~W}, 60 \mathrm{~N}) \text {, } \\
(300 \mathrm{~W}, 240 \mathrm{~N}),(0 \mathrm{~W}, 240 \mathrm{~N}) \text {, } \\
(00 \mathrm{~W}, 00 \mathrm{~N})\end{array}$ & $x$ & $\mathbf{x}$ & $x$ & $\begin{array}{l}\text { High and low magnetic, conductivity and in-phase readings. } \\
\text { The large number of closed contour targets indicate the pres- } \\
\text { ence of numerous anomalies in this area. Anomalies may be } \\
\text { caused by buried ferrous objects or a combination of buried } \\
\text { ferrous objects, other buried metallic debris, and disturbed soil. } \\
\text { The EM data do not show significant anomalous features inside } \\
\text { the area bounded by }(180 \mathrm{~W}, 24 \mathrm{~N}),(225 \mathrm{~W}, 125 \mathrm{~N}) \text {, } \\
(260 \mathrm{~W}, 240 \mathrm{~N}) \text { and }(260 \mathrm{~W}, 80 \mathrm{~N}) \text {. The low magnetic anomaly in } \\
\text { this area may be caused by the proximity of buried ferrous } \\
\text { materials to the east and to the west. It is possible that this } \\
\text { area may be free of buried debris. }\end{array}$ \\
\hline (220W, OON) & $\mathbf{x}$ & $\mathbf{x}$ & $x$ & $\begin{array}{l}\text { Weak magnetic and in-phase anomaly. The Anomaly is small } \\
\text { and probably caused by a near surface small ferrous object(s). }\end{array}$ \\
\hline
\end{tabular}




\section{Site 3-3}

The site map for Site 3-3 is shown in Figure 39. The site is located between Site 3-1 and Site 3-2 (Figure 3). This site contains an area reported to have been previously used for dumping material. Metallic and non-metallic debris such as metal plates, metal pipes, glass labware, etc. were observed scattered over the ground surface near station $(50 \mathrm{~W}, 140 \mathrm{~N})$. The site includes a soil bank that slopes down towards the south from the gravel road as in Site 3-2. The data were collected at $10 \mathrm{ft}$ intervals along the survey lines, with survey lines spaced $20 \mathrm{ft}$ apart. The survey lines were oriented in an eastwest direction. EM-31 conductivity, in-phase, total magnetic field, and magnetic gradient survey results are presented in Figures 40 through 43 , respectively. A description and interpretation of the anomalies is presented in Table 8.

All of the survey results indicate a large anomalous area bounded by stations $(00 \mathrm{~W}, 100 \mathrm{~N}),(00 \mathrm{~W}, 240 \mathrm{~N}),(300 \mathrm{~W}, 200 \mathrm{~N})$, and $(300 \mathrm{~W}, 60 \mathrm{~N})$. As with Sites 3-1 and 3-2 this area also slopes towards the south and it is possible that waste was dumped from the gravel road into this area and later covered with soil. Also, no linear anomalies were interpreted which would indicate the presence of burial trenches. The area in which a gully is located $(230 \mathrm{~W}, 220 \mathrm{~N})$ to $(215 \mathrm{~W}, 210 \mathrm{~N})$ appears to be free of buried debris. The level portion of the site, the area south of a line approximately extending between $(00 \mathrm{~W}, 100 \mathrm{~N})$ and $(300 \mathrm{~W}, 40 \mathrm{~N})$ does not indicate any anomalies.

\section{Site 3-4}

The site map for Site 3-4 is shown in Figure 44. The site measures $300 \mathrm{ft}$ by $140 \mathrm{ft}$ and is relatively level with the exception of a small east-west trending ridge along line $280 \mathrm{~N}$. The data were collected using a $10 \mathrm{ft}$ grid along north-south trending survey lines. EM-31 conductivity, in-phase, total magnetic field, and magnetic gradient survey results are presented in Figures 45 through 48 , respectively. A description and interpretation of the anomalies is presented in Table 9.

As noted in Figures $45-48$ all of the surveys were influenced by the electrical box located at $(250 \mathrm{~N}, 50 \mathrm{E})$. Two weak magnetic gradient anomalies were interpreted and are located near $(120 \mathrm{~N}, 100 \mathrm{E})$ and $(50 \mathrm{~N}, 100 \mathrm{E})$. These anomalies may be caused by small ferrous objects. The results of the conductivity survey (Figure ) show a large, high conductivity zone near the center of the site. The high conductivity in this area may be caused by standing water and saturated soil conditions. No significant anomalies indicative of any burial trenches were interpreted.

\section{Site 4}

Site 4 is suspected of having two trenches containing buried material because of the presence of two shallow (approximately 6 in. deep) elongated ground depressions as shown in Figure 49. EM-31 conductivity, in-phase and 


\section{Table 8}

Geophysical Anomaly Interpretation, Site 3-3

\begin{tabular}{|c|c|c|c|c|c|}
\hline \multirow{2}{*}{ Anomaly Location } & \multicolumn{2}{|c|}{ EM-31 } & \multicolumn{2}{|c|}{ Mag } & \multirow{2}{*}{ Anomaly Description and Interpretation } \\
\hline & C & 1 & $\mathbf{T}$ & G & \\
\hline $\begin{array}{l}\text { Area inside }(00 \mathrm{~W}, 100 \mathrm{~N}),(00 \mathrm{~W}, 240 \mathrm{~N}) \text {, } \\
(300 \mathrm{~W}, 200 \mathrm{~N}) \text {, and }(300 \mathrm{~W}, 60 \mathrm{~N})\end{array}$ & $\mathbf{x}$ & $\mathbf{x}$ & $x$ & $\mathrm{x}$ & $\begin{array}{l}\text { Large anomalous area. Large amounts of ferrous material } \\
\text { buried in this area. Various voids were seen in this area. } \\
\text { Also, debris was scattered eround ( } 50 \mathrm{~W}, 140 \mathrm{~N} \text { ). The area } \\
\text { along which the gully runs appears to be debris free. }\end{array}$ \\
\hline
\end{tabular}

\section{Table 9}

Geophysical Anomaly Interpretation, Site 3-4

\begin{tabular}{||l|l|l|l|l|l||}
\hline \multirow{2}{*}{ Anomaly Location } & \multicolumn{2}{|c||}{ EM-31 } & \multicolumn{2}{l|}{ Mag } & \multirow{2}{*}{ Anomaly Description and Interpretation } \\
\cline { 2 - 6 } & C & I & T & G & \\
\hline \hline$(250 \mathrm{~N}, 60 \mathrm{E})$ & $\mathrm{X}$ & $\mathrm{X}$ & $\mathrm{X}$ & $\mathrm{X}$ & Anomaly caused by olectrical junction box. \\
\hline$(120 \mathrm{~N}, 100 \mathrm{E})$ & & & & $\mathrm{X}$ & Anomaly probably caused by buried ferrous object. \\
\hline$(50 \mathrm{~N}, 100 \mathrm{E})$ & & & & $\mathrm{X}$ & Anomaly probably caused by a buried ferrous object. \\
\hline
\end{tabular}


total magnetic field, surveys were conducted and the results of these surveys are presented in Figures 50 through 52, respectively. The survey lines were oriented in an east-west direction and data collected using a $10 \mathrm{ft}$ grid interval. A description and interpretation of the anomalies is presented in Table 10.

Only one anomalous area was interpreted as a result of the surveys conducted at this site. The anomalous area located in the vicinity of $(45 \mathrm{~W}, 40 \mathrm{~N})$ was interpreted from the in-phase and total magnetic field data. The magnetic response is rather weak whereas the in-phase is rather intense. This anomaly occurs in the proximity of the western ground depression. It is possible that the ground depression may delineate the boundaries of a small disposal pit containing a small amount of ferrous material.

\section{Site 13}

Site 13 is located in the northwestern portion of Area B as shown in Figure 3. The site map for Site 13 is shown in Figure 53. This was a relatively small site and measured $300 \mathrm{ft}$ by $120 \mathrm{ft}$. The site is fairly level and featureless. Interpretations of aerial photographs suggest the possibility of this site being a former disposal area. The data were collected using a $10 \mathrm{ft}$ grid along north-south trending survey lines. EM-31 conductivity, in-phase, total magnetic field, and magnetic gradient survey results are presented in Figures 54 through 57, respectively. A description and interpretation of the anomalies is presented in Table 11.

Two minor anomalies located at $(10 \mathrm{E}, 60 \mathrm{~N})$ and $(10 \mathrm{E}, 270 \mathrm{~N})$ were interpreted from the EM data. The anomalies occur among a line of small evergreen trees and are not considered to be indicative of past disposal activities.

\section{Gate Site}

The Gate Site is located between the entrance to the sanitary landfill and Bldg. S-1222 (Figure 3). The site map for the Gate Site is shown in Figure 58. The site is located on a hillside which slopes down towards the northeast. Several ground hog burrows with debris strewn around their perimeter were observed. Evidently, the ground hogs dug the debris out of the ground while in the process of excavating their burrows. The data were collected using a $10 \mathrm{ft}$ grid run parallel to the hill contours in a northwestsoutheast trending direction. EM-31 conductivity, in-phase, total magnetic field, and magnetic gradient survey results are presented in Figures 59 through 62 , respectively. A description and interpretation of the anomalies is presented in Table 12.

Several anomalous features were interpreted for this site. A large anomaly was interpreted in the upper part of the site. Because of the extent of this anomalous area and because it borders an active landfill, it is suspected that this area may have been used as a landfill in the past. The conductivity survey indicated an anomalous area inside the bounds of $(150 \mathrm{~N}, 110 \mathrm{~W})$, 


\begin{tabular}{|c|c|c|c|c|}
\hline \multicolumn{5}{|c|}{$\begin{array}{l}\text { Table } 10 \\
\text { Geophysical Anomaly Interpretation, Site } 4\end{array}$} \\
\hline \multirow[b]{2}{*}{ Anomaly Location } & \multicolumn{2}{|c|}{ EM-31 } & \multirow{2}{*}{ Mag } & \multirow[b]{2}{*}{ Anomaly Description and Interprotation } \\
\hline & c & $\mathbf{I}$ & & \\
\hline$(45 \mathrm{~W}, 40 \mathrm{~N})$ & & $x$ & $x$ & $\begin{array}{l}\text { Small, intense, in-phase anomaly and weak magnetic anomaly. } \\
\text { The anomaly may be associated with the western ground de- } \\
\text { pression. The anomaly is probably caused by a small buried } \\
\text { ferrous object(s). }\end{array}$ \\
\hline
\end{tabular}

\begin{tabular}{|c|c|c|c|c|c|}
\hline \multicolumn{6}{|c|}{$\begin{array}{l}\text { Table } 11 \\
\text { Geophysical Anomaly Interpretation, Site } 13\end{array}$} \\
\hline \multirow[b]{2}{*}{ Anomaly Location } & \multicolumn{2}{|c|}{ EM-31 } & \multicolumn{2}{|c|}{ Mag } & \multirow[b]{2}{*}{ Anomaly Description and Interpretation } \\
\hline & c & 1 & $T$ & c & \\
\hline$(10 E, 60 N)$ & & $x$ & & & $\begin{array}{l}\text { Small in-phase anomaly that may be caused by a small } \\
\text { metallic object. Anomaly is located along tree line. }\end{array}$ \\
\hline (10E, 27ON) & $x$ & $x$ & 4 & & $\begin{array}{l}\text { Small conductivity and in-phase anomaly that may be } \\
\text { caused by a small metallic object. Anomaly is located along } \\
\text { tree line. }\end{array}$ \\
\hline
\end{tabular}




\section{Table 12}

Geophysical Anomaly Interpretation, Gate Site

\begin{tabular}{|c|c|c|c|c|c|}
\hline \multirow{2}{*}{ Anomaly Location } & \multicolumn{2}{|c|}{ EM-31 } & \multicolumn{2}{|c|}{ Mag } & \multirow{2}{*}{ Anomaly Description and Interpretation } \\
\hline & c & 1 & $T$ & G & \\
\hline $\begin{array}{l}\text { Area inside }(00 \mathrm{~N}, 120 \mathrm{~W}),(00 \mathrm{~N}, 200 \mathrm{~W}) \text {, } \\
(160 \mathrm{~N}, 200 \mathrm{~W}),(180 \mathrm{~N}, 120 \mathrm{~W}), \\
(100 \mathrm{~N}, 80 \mathrm{~W})\end{array}$ & $x$ & $\mathbf{x}$ & $x$ & $x$ & $\begin{array}{l}\text { Large anomalous area. Many holes and debris scattered } \\
\text { over this area. This may be an old landfill area. }\end{array}$ \\
\hline $\begin{array}{l}\text { Area inside }(150 \mathrm{~N}, 110 \mathrm{~W}), \\
(180 \mathrm{~N}, 110 \mathrm{~W}),(200 \mathrm{~N}, 50 \mathrm{~W}), \\
(200 \mathrm{~N}, 30 \mathrm{~W}),(170 \mathrm{~N}, 20 \mathrm{~W})\end{array}$ & $\mathbf{x}$ & & & & Anomaly may be caused by a metallic source. \\
\hline$(125 \mathrm{~N}, 00 \mathrm{~W})-(200 \mathrm{~N}, 25 \mathrm{~W})$ & $x$ & & $x$ & $\mathbf{x}$ & $\begin{array}{l}\text { Anomaly is located near Bldg. S-1222. Anomaly may be } \\
\text { caused by a buried ferrous object or a buried utility line. }\end{array}$ \\
\hline
\end{tabular}


$(180 \mathrm{~N}, 110 \mathrm{~W}),(200 \mathrm{~N}, 50 \mathrm{~W}),(200 \mathrm{~N}, 30 \mathrm{~W})$ and $(170 \mathrm{~N}, 20 \mathrm{~W})$. This anomaly may be caused by buried non-ferrous metallic material. The anomaly located between $(125 \mathrm{~N}, 00 \mathrm{~W})$ and $(200 \mathrm{~N}, 25 \mathrm{~W})$ near Bldg. S-1222 is not considered to be related to past disposal activities because of its size and its proximity to the building.

\section{Antenna Site}

The location of the Antenna Site is shown in Figure 3. The site map showing the location of wire fences, ground hog burrows, debris and other pertinent features is displayed in Figure 63. The data were collected using a $10 \mathrm{ft}$ grid along survey lines that were oriented in a north-south direction. EM-31 conductivity, in-phase, total magnetic field, and magnetic gradient survey results are presented in Figures 64 through 67, respectively. A description and interpretation of the anomalies is presented in Table 13.

In each of the data plots the effect of the wire fences on the surveys is readily apparent. Two significant anomalous areas were interpreted from the surveys. The first anomaly is located approximately inside the bounds of $(50 \mathrm{~N}, 310 \mathrm{~W}),(50 \mathrm{~N}, 175 \mathrm{~W}),(200 \mathrm{~N}, 175 \mathrm{~W})$ and $(200 \mathrm{~N}, 310 \mathrm{~W})$. This anomaly is located in an area where brick, ceramic tile and cinder block fragments were visible on the ground surface. As was the case at the Gate Site it appears as if ground hogs may have unearthed some of this rubble. It is very probable that this area may have been used as a disposal site at one time because of the rubble found on the ground surface and the strong anomalies indicated by all of the survey methods. The second significant anomaly is located between approximate stations $(00 \mathrm{~N}, 140 \mathrm{~W})$ and $(250 \mathrm{~N}, 90 \mathrm{~W})$ and is approximately $50 \mathrm{ft}$ wide. This area is also suspected of being used as a disposal area at one time because of the strong signal response of all of the surveys and because of the "trench-like" (long and narrow) shape of the anomaly. The other anomalies found at the site are not considered to be associated with past disposal activities.

\section{Army Reserve Site}

The Army Reserve Site is located approximately $600 \mathrm{ft}$ west of the Army Reserve Training Center which is located on Rocky Springs Road as shown in Figure 3. The site map showing several surface features is presented in Figure 68. The data were collected using a $10 \mathrm{ft}$ grid along survey lines that were oriented in a north-south direction. EM-31 conductivity, in-phase, total magnetic field, and magnetic gradient survey results are presented in Figures 69 through 72, respectively. A description and interpretation of the anomalies is presented in Table 14.

One prominent anomaly can be seen in all of the data plots. This anomaly is a linear feature extending between $(240 \mathrm{~N}, 05 \mathrm{E})$ and $(90 \mathrm{~N}, 180 \mathrm{E})$. This anomaly is presumed to be associated with an underground utility line since evidence of recent soil disturbance associated with trenching and backfilling 
operations can be seen in this area. No significant anomalies associated with previous disposal activities were interpreted for this site.

\section{Igloo Site 1}

Igloo Site 1 is located approximately $500 \mathrm{ft}$ south of the Army Reserve Site in the eastern part of Area B (Figure 3). The site map showing several surface features is presented in Figure 73. The data were collected using a $10 \mathrm{ft}$ grid along survey lines that were oriented in a north-south direction. EM-31 conductivity, in-phase, total magnetic field, and magnetic gradient survey results are presented in Figures 74 through 77, respectively. A description and interpretation of the anomalies is presented in Table 15.

Several anomalies were interpreted from the surveys conducted at this site. Two anomalies one located at $(35 \mathrm{~N}, 170 \mathrm{E})$ and the other located at $(125 \mathrm{~N}, 80 \mathrm{E})$ are caused by a steel hay feeder and a 4-in. steel pipe protruding from the ground surface, respectively. The conductivity survey (Figure 74) indicates an anomaly extending between $(220 \mathrm{~N}, 00 \mathrm{E})$ and $(265 \mathrm{~N}, 200 \mathrm{E})$. This anomaly corresponds with the location of a buried gas pipeline. The conductivity survey also indicated an area with anomalously high conductivity values in the area near $(30 \mathrm{~N}, 75 \mathrm{E})$. This anomaly may be caused by a change in subsurface soil conditions such as an increase in clay or water content. It is possible that this area could be an old disposal trench containing little or no ferrous material. Two additional anomalies located at $(80 \mathrm{~N}, 170 \mathrm{E})$ and $(275 \mathrm{~N}, 110 \mathrm{E})$ were detected by all of the surveys. These anomalies are rather localized and are probably areas where small amounts of debris are buried.

\section{Igloo Site 2}

Igloo Site 2 is located adjacent to and south of Igloo Site 1 in the eastern part of Area B (Figure 3). The site map of this area showing several surface features is presented in Figure 78. The data were collected using a $10 \mathrm{ft}$ grid along survey lines that were oriented in a north-south direction. EM-31 conductivity, in-phase, total magnetic field, and magnetic gradient survey results are presented in Figures 79 through 82, respectively. A description and interpretation of the anomalies is presented in Table 16.

Two significant anomalies were interpreted for this site. An anomalous area near $(130 \mathrm{E}, 60 \mathrm{~N})$ approximately $30 \mathrm{ft}$ in diameter was detected by all of the survey methods. Partially buried metallic debris was observed in this area. Another anomalous area approximately $40 \mathrm{ft}$ in width and located between $(50 \mathrm{E}, 00 \mathrm{~N})$ and $(50 \mathrm{E}, 140 \mathrm{~N})$ was detected by the conductivity survey. This anomaly appears to be a southern extension of the high conductivity anomaly that occurs at Igloo Site $1(30 \mathrm{~N}, 75 \mathrm{E})$. 


\begin{tabular}{|c|c|c|c|c|c|}
\hline \multicolumn{6}{|c|}{$\begin{array}{l}\text { Table } 13 \\
\text { Geophysical Anomaly Interpretation, Antenna Site }\end{array}$} \\
\hline \multirow[b]{2}{*}{ Anomaly Location } & \multicolumn{2}{|c|}{ EM-31 } & \multicolumn{2}{|c|}{ Mag } & \multirow[b]{2}{*}{ Anomaly Description and Interpretation } \\
\hline & c & 1 & $\mathbf{T}$ & G & \\
\hline $\begin{array}{l}\text { Area inside }(50 \mathrm{~N}, 310 \mathrm{~W}),(50 \mathrm{~N}, 175 \mathrm{~W}) \\
(200 \mathrm{~N}, 175 \mathrm{~W}) \text {, and }(200 \mathrm{~N}, 310 \mathrm{~W})\end{array}$ & $x$ & $x$ & $x$ & $x$ & $\begin{array}{l}\text { Anomaly covers a large area and is located in an area where } \\
\text { pieces of bricks, ceramic tiles, cinder blocks were found on } \\
\text { the ground surface. Several voids were also seen in this } \\
\text { area. Non-ferrous and/or ferrous material is probably buried } \\
\text { in this area. }\end{array}$ \\
\hline $\begin{array}{l}\text { Area along line }(00 \mathrm{~N}, 140 \mathrm{~W}) \text {, } \\
\text { (250N,90W) }\end{array}$ & $x$ & $x$ & $x$ & $x$ & $\begin{array}{l}\text { Elongated anomaly approximately } 250 \mathrm{ft} \text { long. The linear } \\
\text { shapo suggests a possible disposal tronch. Matorial may } \\
\text { include ferrous and non-ferrous materials. }\end{array}$ \\
\hline (210N,380W) & & & $x$ & $\mathrm{x}$ & $\begin{array}{l}\text { Very localized anomaly. Probably caused by a buried ferrous } \\
\text { object. }\end{array}$ \\
\hline$(400 \mathrm{~N}, 380 \mathrm{~W})$ & & & $x$ & $x$ & $\begin{array}{l}\text { Very localized anomaly. Probably caused by a buried ferrous } \\
\text { object. }\end{array}$ \\
\hline (475N,375W) & $x$ & $x$ & 1 & & $\begin{array}{l}\text { Anomaly in this area probably caused by antenna guy wires } \\
\text { and antenna which is located at (50ON,445W). It is also } \\
\text { possible that this anomaly is associated with the magnetic } \\
\text { anomaly located at ( } 400 \mathrm{~N}, 380 \mathrm{~W} \text { ). }\end{array}$ \\
\hline$(410 \mathrm{~N}, 80 \mathrm{~W})$ & & & $x$ & $x$ & $\begin{array}{l}\text { Localized magnetic anomaly caused by steel guy wire an- } \\
\text { chor. }\end{array}$ \\
\hline
\end{tabular}


Table 14

Geophysical Anomaly Interpretation, Army Reserve Site

\begin{tabular}{||l|l|l|l|l|l||}
\hline \multirow{2}{*}{ Anomaly Location } & \multicolumn{2}{|c|}{ EM-31 } & \multicolumn{2}{|l|}{ Mag } & \multirow{2}{*}{ Anomaly Description and Interpretation } \\
\cline { 2 - 5 } & C & I & T & G & X \\
\hline \hline (240N,05E)-(9ON,180E) & $X$ & $X$ & $X$ & $X$ & $\begin{array}{l}\text { Elongated anomaly running diagonally from the lower left- } \\
\text { hand corner to the upper center of the site. Visible soil } \\
\text { disturbance suggests a buried utility line in this area. }\end{array}$ \\
\hline$(100 N, 110 E)$ & & & $X$ & $X$ & Small anomaly probably caused by a buried ferrous object. \\
\hline
\end{tabular}

\section{Table 15}

Geophysical Anomaly Interpretation, Igloo Site, Section 1

\begin{tabular}{|c|c|c|c|c|c|}
\hline \multirow{2}{*}{ Anomaly Location } & \multicolumn{2}{|c|}{ EM-31 } & \multicolumn{2}{|c|}{ Mag } & \multirow{2}{*}{ Anomaly Description and Interprotation } \\
\hline & c & 1 & $\mathbf{T}$ & G & \\
\hline (3ON,75E) & $x$ & $\mathrm{x}$ & & & $\begin{array}{l}\text { Elongated anomaly oriented N-S. Strong conductivity re- } \\
\text { sponse and weak in-phase response. Probable causes for } \\
\text { anomaly are a change in soil type or buried non-ferrous } \\
\text { material. }\end{array}$ \\
\hline (35N, 170E) & $x$ & $x$ & $x$ & $x$ & Anomaly caused by steel hay feeder. \\
\hline (8ON, 135E) & $x$ & $x$ & $x$ & $x$ & $\begin{array}{l}\text { Very localized anomaly. Probably caused by a buried ferrous } \\
\text { object. }\end{array}$ \\
\hline (125N,80E) & $x$ & $x$ & $x$ & $\mathrm{x}$ & $\begin{array}{l}\text { Anomaly caused by a visible small concrete pad with a } \\
\text { protruding } 4 \text { in. steal pipe. }\end{array}$ \\
\hline$(220 \mathrm{~N}, 00 \mathrm{E})-(265 \mathrm{~N}, 200 \mathrm{E})$ & $x$ & & & & $\begin{array}{l}\text { The conductivity anomaly is caused by a buried gas pipe- } \\
\text { line. The location of the pipeline is marked by signs. }\end{array}$ \\
\hline (275N,110E) & $x$ & $x$ & $x$ & $x$ & $\begin{array}{l}\text { Anomaly located in an area with voids in the ground and } \\
\text { scattered concrete chunks. }\end{array}$ \\
\hline
\end{tabular}




\begin{tabular}{|c|c|c|c|c|c|}
\hline \multicolumn{6}{|c|}{$\begin{array}{l}\text { Table } 16 \\
\text { Geophysical Anomaly Interpretation, Igloo Site, Section } 2\end{array}$} \\
\hline \multirow[b]{2}{*}{ Anomaly Location } & \multicolumn{2}{|c|}{ EM-31 } & \multicolumn{2}{|c|}{ Mag } & \multirow[b]{2}{*}{ Anomaly Description and Interpretation } \\
\hline & c & 1 & $\mathbf{T}$ & G & \\
\hline (4OE,3ON) & $x$ & $x$ & $x$ & $x$ & Anomaly caused by nearby mower. \\
\hline (50E,OON)-(50E, 140N) & $x$ & & & & $\begin{array}{l}\text { Elongated conductivity anomaly approximately } 20 \mathrm{ft} \text { wide. } \\
\text { Probably caused by a change in soil material. }\end{array}$ \\
\hline (130E,60N) & $x$ & $x$ & $x$ & $x$ & $\begin{array}{l}\text { Anomaly located over an area with voids and partially buried } \\
\text { motal dobris. }\end{array}$ \\
\hline
\end{tabular}




\section{Refraction Site}

The seismic refraction surveys were conducted inside the western boundary of the circular-shaped test grid located near the center of Area B as shown in Figure 3. Four, end-to-end refraction lines, each $110 \mathrm{ft}$ long were run in this area (Figure 83). As mentioned previously a sledgehammer was used as the seismic energy source for these surveys. The amount of energy that can be imparted into the ground using this type of source is limited by the strength of the person swinging the hammer. As a result of the combination of soil type and the use of a sledgehammer as a source, the P-wave signal was very weak beyond a distance of approximately $70 \mathrm{ft}$. Unfortunately, the waves refracted from the top of the sound bedrock begin to arrive at or beyond this distance. This reduces the ability to determine the velocity and depth to bedrock accurately. However, the data are considered to be of sufficient quality to permit an assessment of the P-wave velocities and depths to interfaces.

The time-distance (TD) plots for refraction lines 1-4 are presented in Figures 84 through 87 , respectively. Figure 88 presents the P-wave velocity profile computed from the TD plots. Averaged velocities for each layer and average depths beneath each shot point are shown in Figure 89. The averaged velocity profile indicates the presence of 3 velocity layers corresponding to overburden, weathered rock and sound rock. The average P-wave velocities for layers 1 through 3 are 690-, 2370- and 10,940 fps, respectively (Figure 89). The thickness of the overburden is approximately $2 \mathrm{ft}$ for this area. The depth to sound bedrock ranges between approximately 27 and $32 \mathrm{ft}$. The P-wave velocity for the sound bedrock (layer 3 ) ranges between 10,550 and $11,190 \mathrm{fps}$. No significant bedrock velocity variation or bedrock offset was ascertained. The small difference in bedrock velocity and in top of rock depths cannot be considered proof that a fault crosses this area. On the other hand it does not prove that one does not cross this area. The possibility exists that the true rock velocities on either side of a fault may be of the same magnitude in which case the seismic refraction method would have difficulty in distinguishing such a fault. 


\section{Summary and Conclusions}

A geophysical investigation was conducted at Area B to delineate anomalous areas indicative of prior disposal activities. Magnetic, EM, and GPR geophysical survey methods were employed to meet this objective. Fifteen sites totaling an area of approximately 23 acres were surveyed. All of the surveyed sites indicated the presence of anomalous conditions and their locations were noted. Some of the interpreted anomalies may be related to prior disposal activities. Sites exhibiting anomalous features highly indicative of buried waste and/or burial trenches or pits include:
a. Site 1-1
b. Site 1-2
c. Site 2-2
d. Site 3-1
e. Site 3-2
f. Site 3-3
g. Gate Site
h. Antenna Site
i. Igloo Site 1
j. Igloo Site 2

The anomalies interpreted for Sites 3-4, 4, 13 and the Army Reserve Site are very limited in size and intensity and are not considered to be associated with a designed disposal operation.

The refraction survey across the site of the suspected fault was not conclusive. Additional seismic refraction surveys using a stronger energy source are recommended in order to detect and delineate the suspected fault. 


\section{References}

Department of the Army (1979). "Geophysical exploration," Engineer Manual EM 1110-1-1802, Office of the Chief of Engineers, Washington, D.C.

Barrows, L. and Rocchio, J. E. (1990). "Magnetic surveying for buried metallic objects," Ground Water Monitoring Review 10(3), 204-211.

Bevan, B. W. (1983). "Electromagnetics for mapping buried earth features," Journal of Field Archaeology 10, 47-54.

Breiner, S. (1973). "Applications manual for portable magnetometers", Geometrics, Sunnyvale, CA.

Butler, D. K. (1986). "Military Hydrology; Report 10: Assessment and field examples of continuous wave electromagnetic surveying for ground water," Miscellaneous Paper EL-79-6, U.S. Army Engineer Waterways Experiment Station, Vicksburg, MS.

Butler, D. K. and Llopis, J. L. (1990). "Assessment of Anomalous Seepage Conditions." Geotechnical and Environmental Geophysics, Volume II: Environmental and Groundwater. Soc. Explor. Geoph., Tulsa, OK.

Department of the Army (1977). "Installation Assessment of Fort Detrick, Maryland," Record Evaluation Report No. 106, Vol. 1, Office of the Project Manager for Chemical Demilitarization and Installation Restoration, Aberdeen Proving Ground, MD.

Geonics Limited (1984). "Operating manual for EM31-D non-contacting terrain conductivity meter," Mississauga, Ontario, Canada.

McNeil, J. D. (1980). "Electromagnetic terrain conductivity measurements at low induction numbers," Technical Note TN-6, Geonics Limited, Mississauga, Ontario, Canada.

Nabighian, M. N. (1988). Electromagnetic methods in applied geophysics, Vol. 1, Soc. Explor. Geoph., Tulsa, OK. 
Olhoeft, G. R. (1984). "Applications and limitations of ground penetrating radar," 54th Ann. Internat. Mtg. Expanded Abstracts, Soc. Explor.

Geoph., Tulsa, OK, 147-148

Palmer, D. (1980). The generalized reciprocal method of seismic refraction interpretation. Soc. Explor. Geoph., Tulsa, OK.

Redpath, B. B. (1973). "Seismic refraction exploration for engineering site investigations," Technical Report E-73-4, U.S. Army Engineer Waterways Experiment Station, Vicksburg, MS.

Telford, W. M., Geldhart, L. P., Sheriff, R. E., and Keys, D. A. (1973). Applied Geophysics, Cambridge University Press, NY.

US Army Engineer District, Baltimore (1983). " "Study of proposed sanitary landfill Area B, Fort Detrick, Maryland," Baltimore, MD.

32 


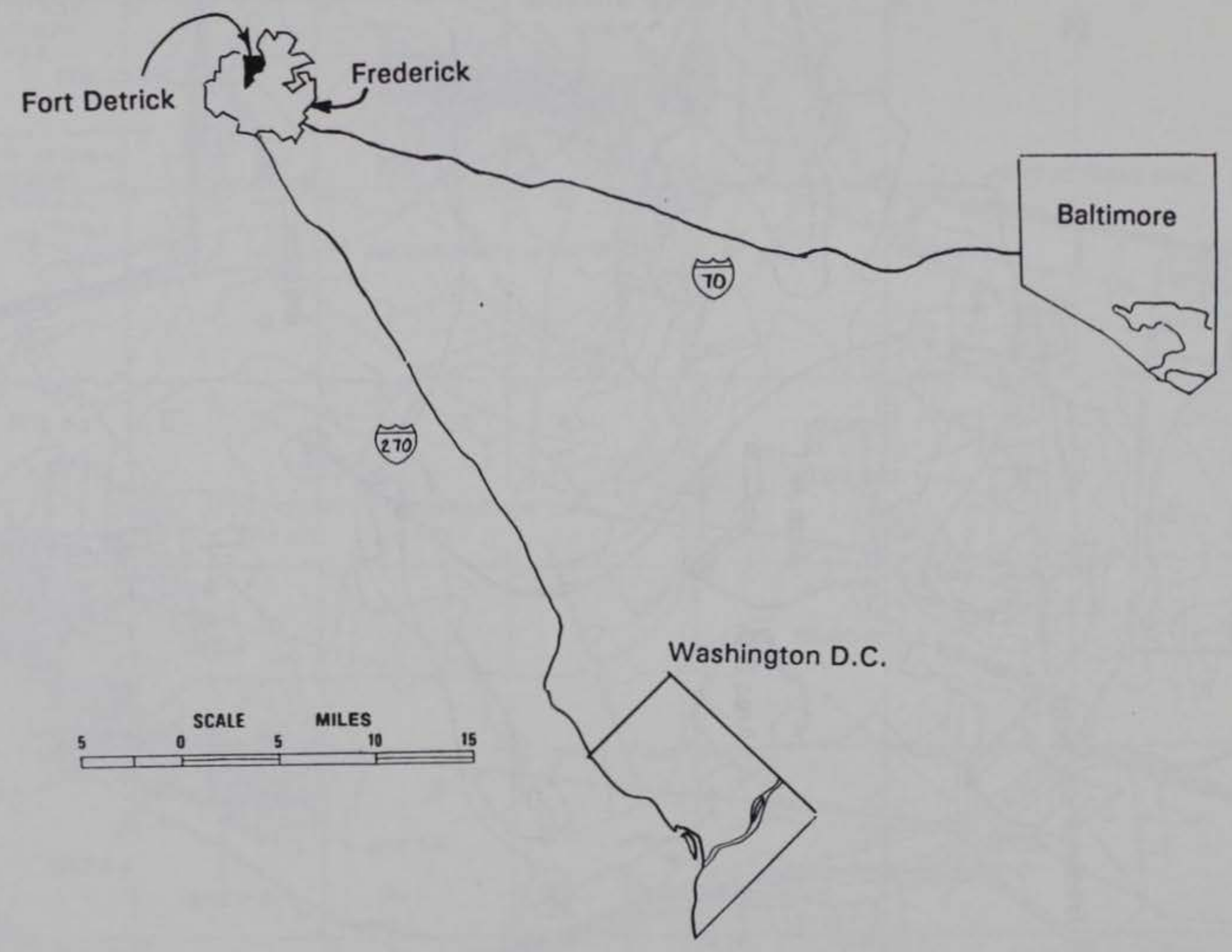

Figure 1. Vicinity map 


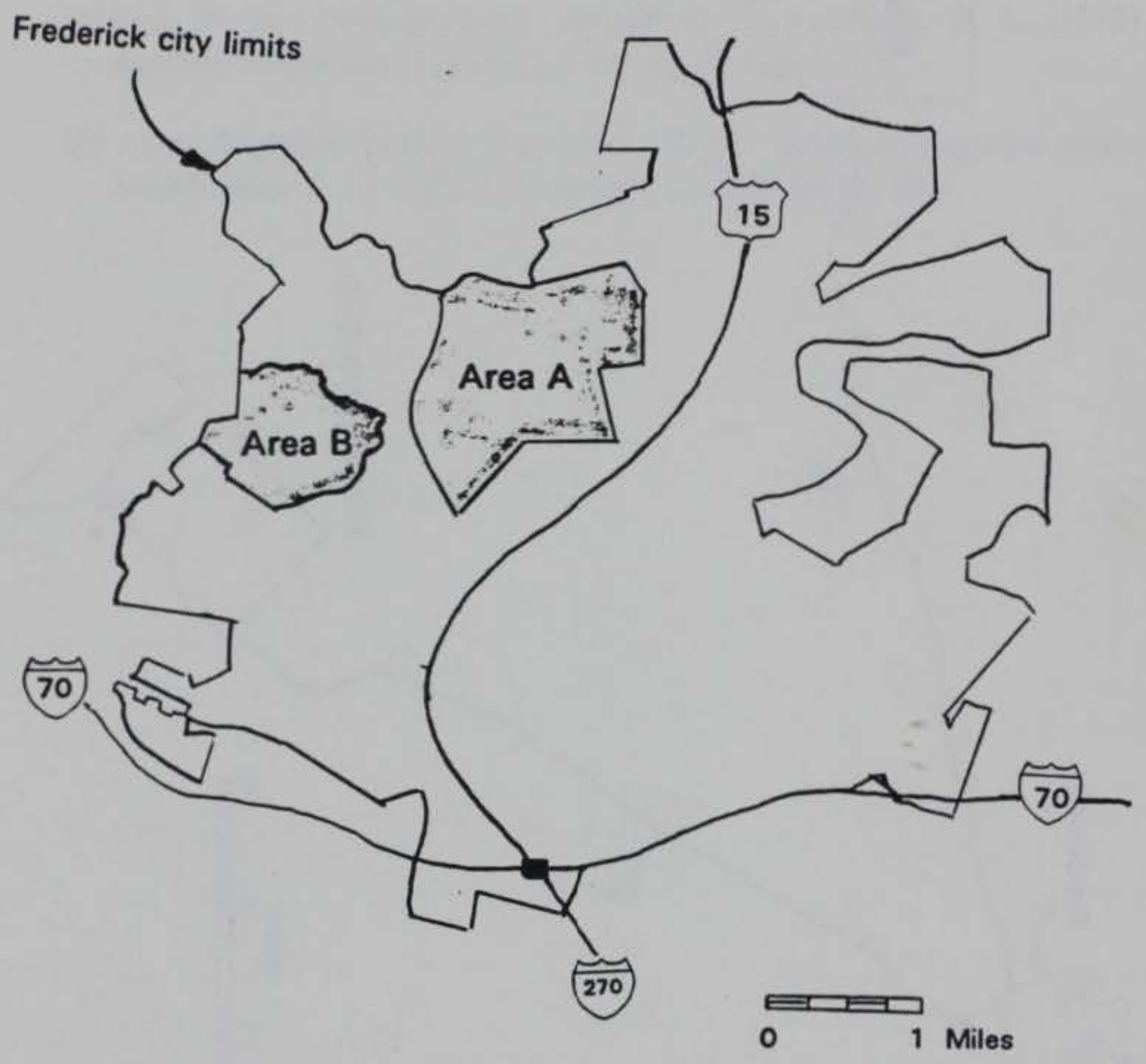

Figure 2. Location of Areas A and B, Fort Detrick 


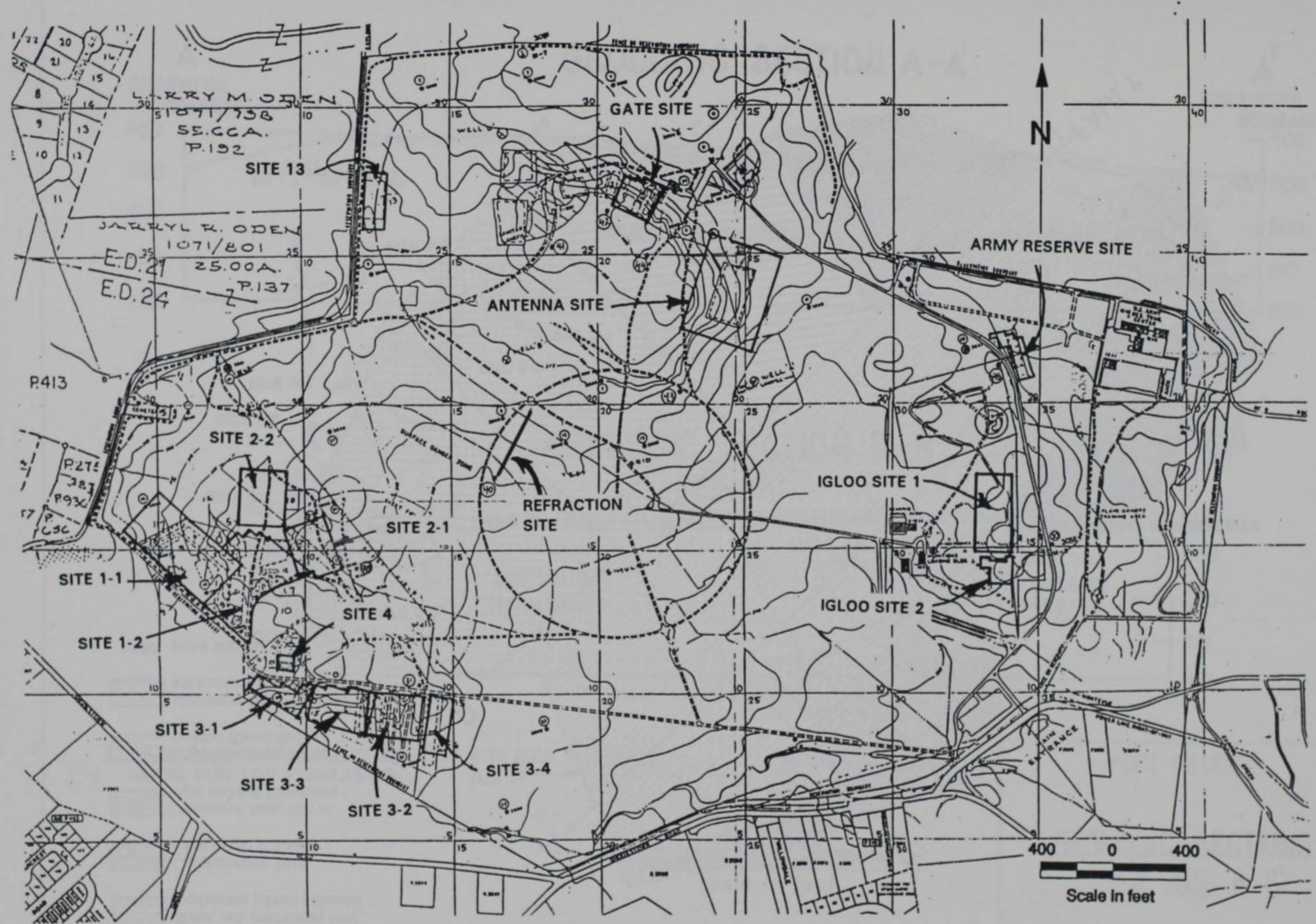

Figure 3. Location of geophysical test sites 


\section{LEGEND}

Shale, red, moderately hard

moderately jointed (Triassic)

0.\% Conglomerate, hard,

solutionized (Trlassic)

Umestone, hard, thin to

Umestone, hard, thin bedded (Cambrian)

$\because$ Umestone, hard, massive, solutionized (Cambrian)

$\vdash 50$ strike and dip
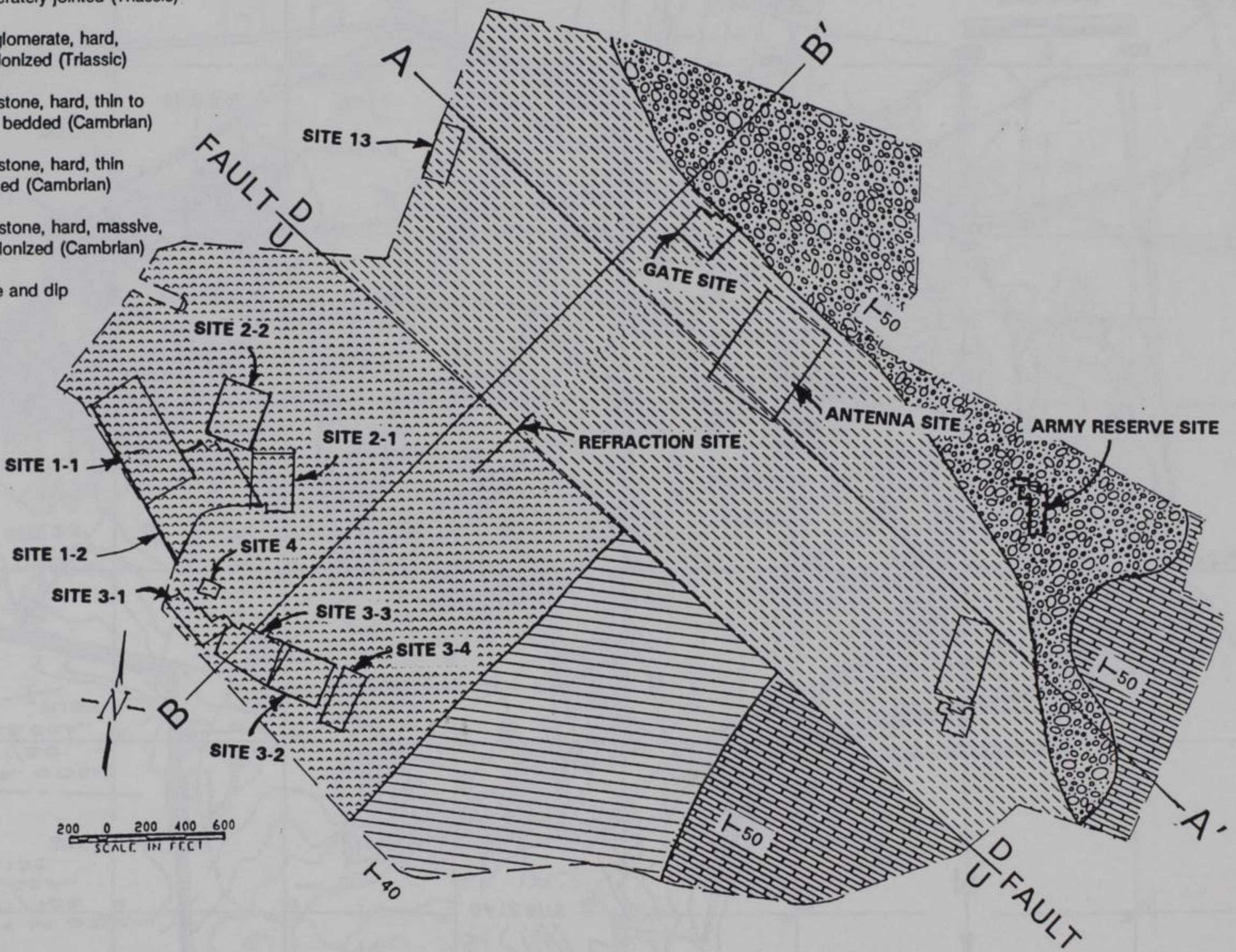

Figure 4. Geologic map of Area B 


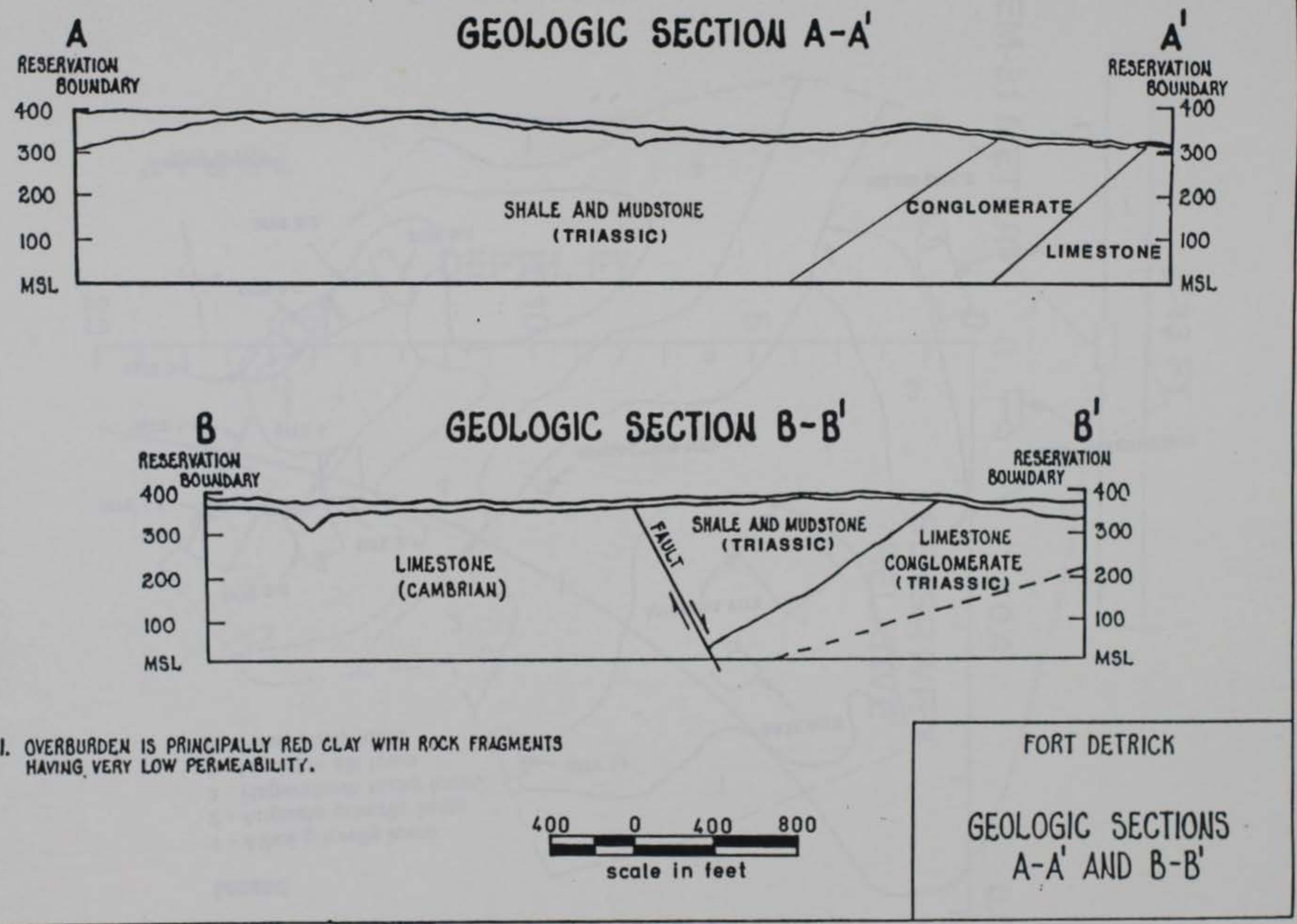

Figure 5. Geologic cross section, Area B 


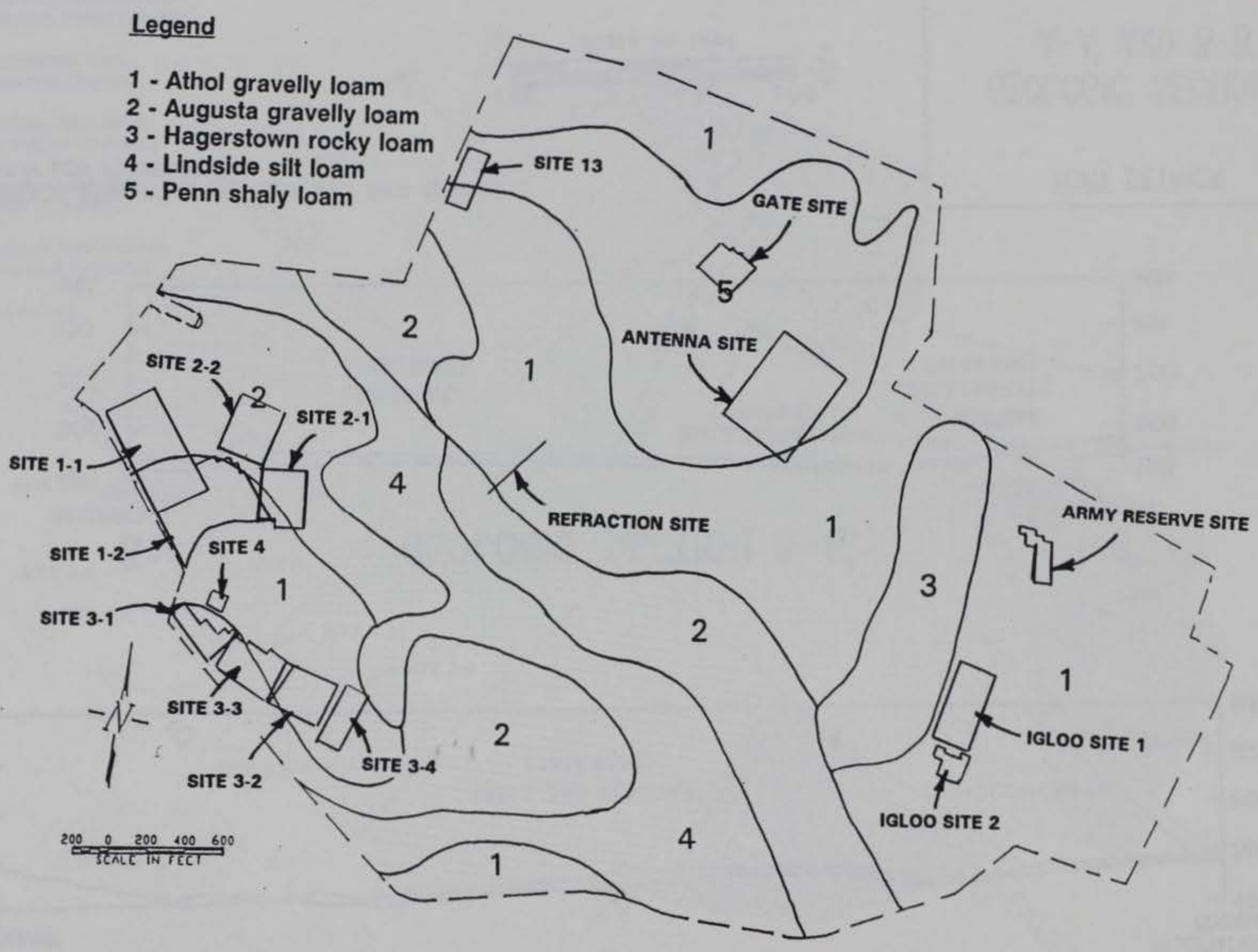

Figure 6. Areal distribution of soils, Area B 


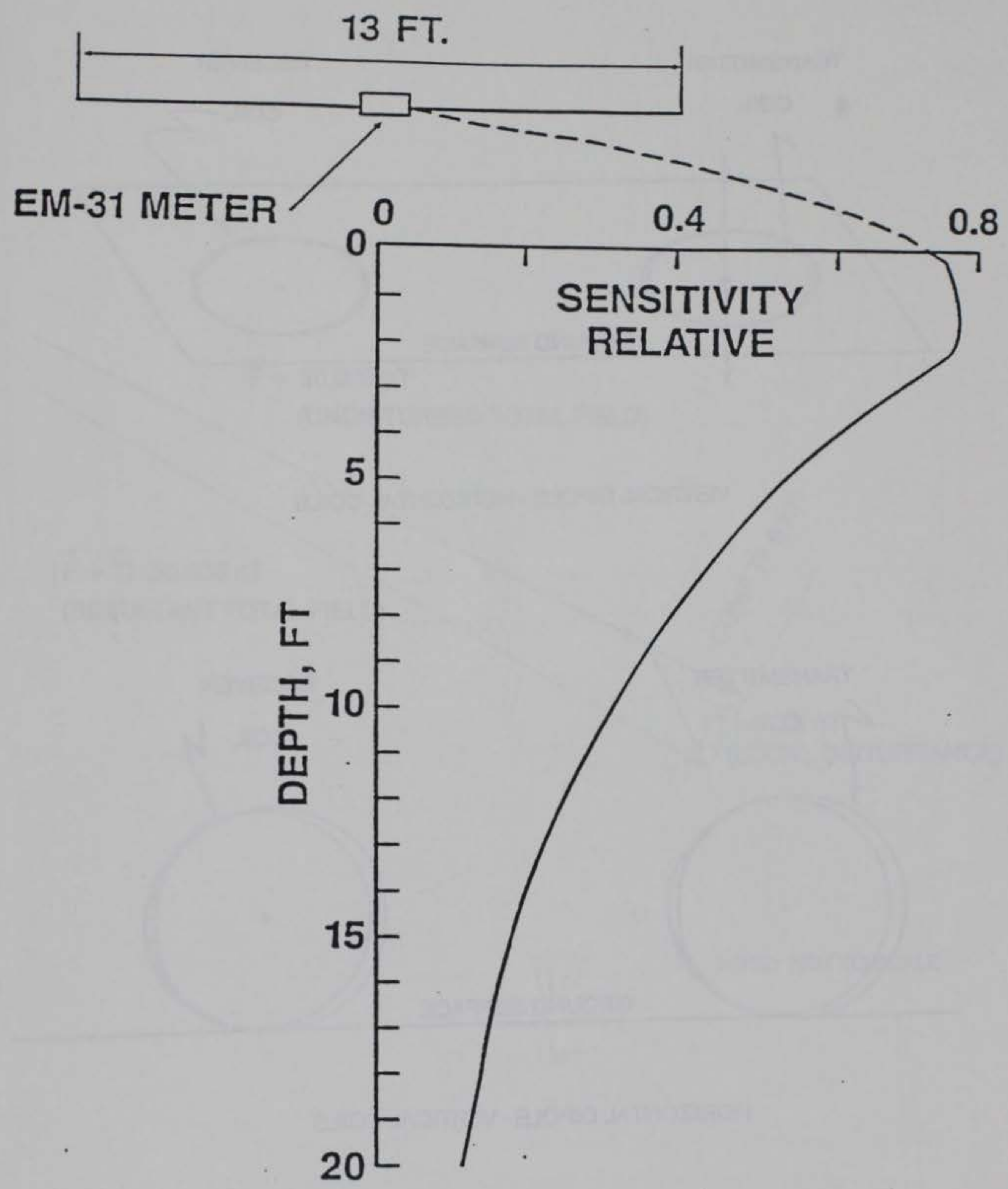

Figure 7. Sensitivity versus depth for the EM-31 terrain conductivity meter 
TRANSMITTER

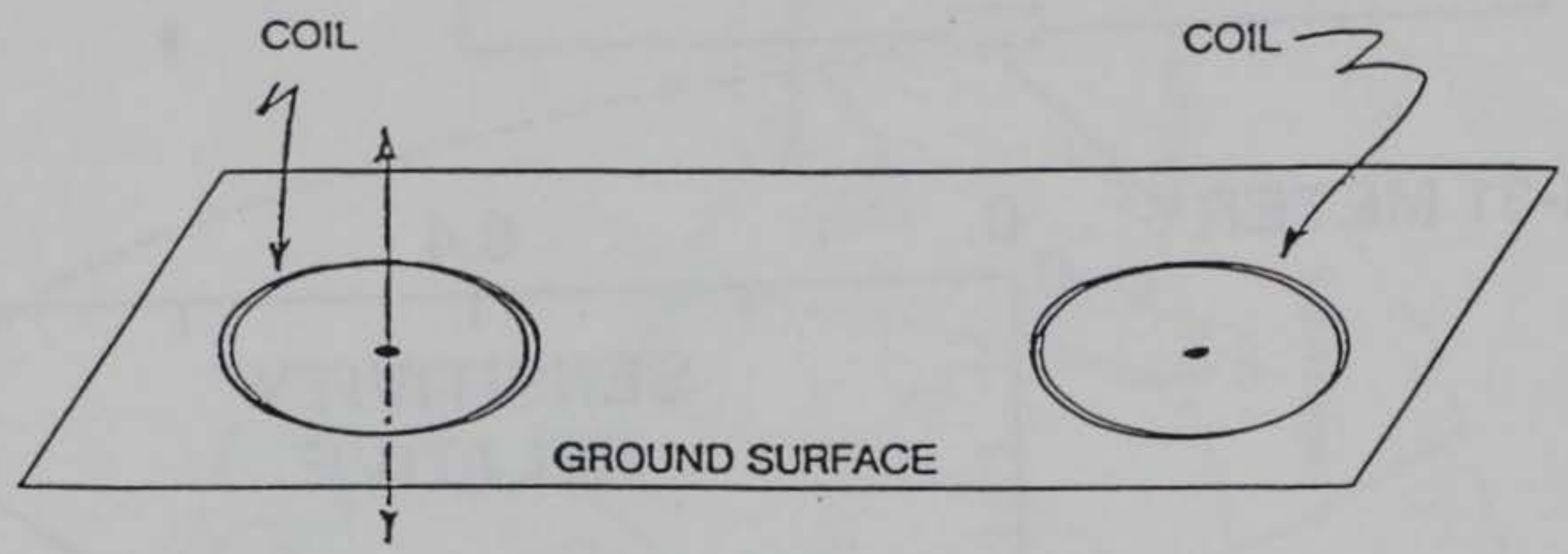

VERTICAL DIPOLE - HORIZONTAL COILS

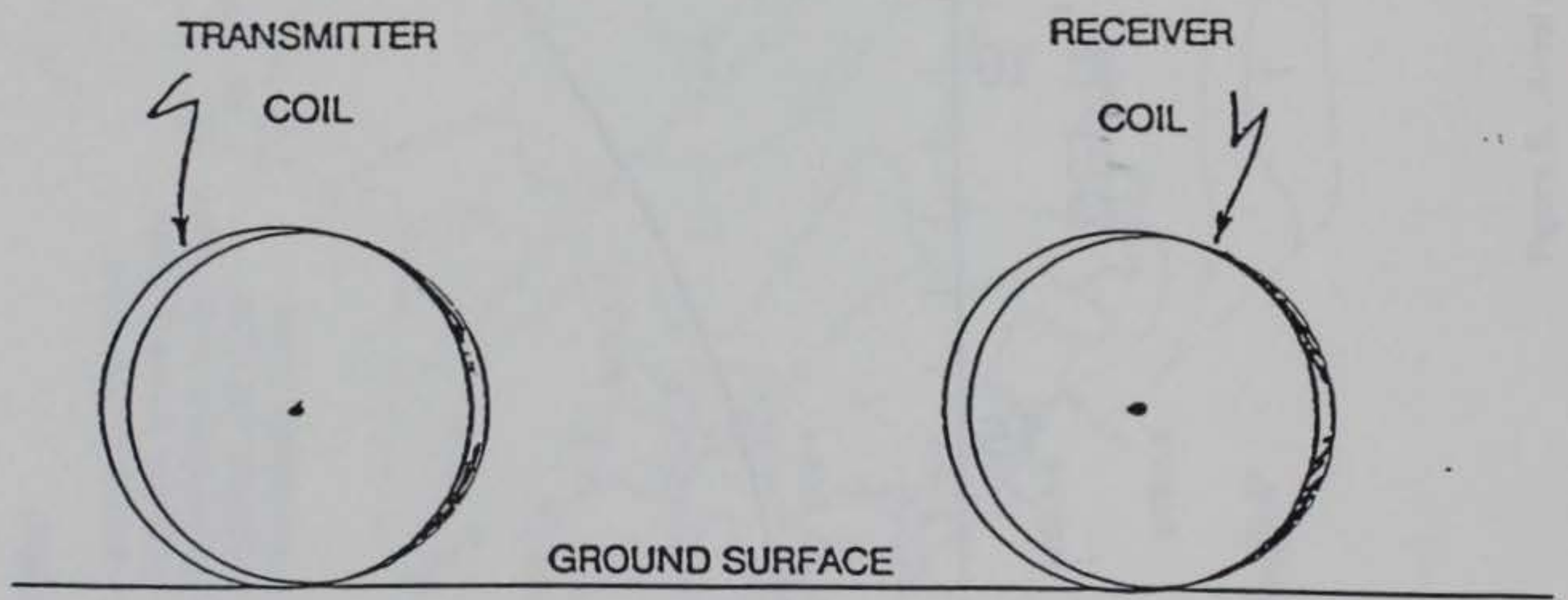

HORIZONTAL DIPOLE - VERTICAL COILS

Figure 8. Schematic illustration of the EM-31 transmitter and receiver coil orientations 


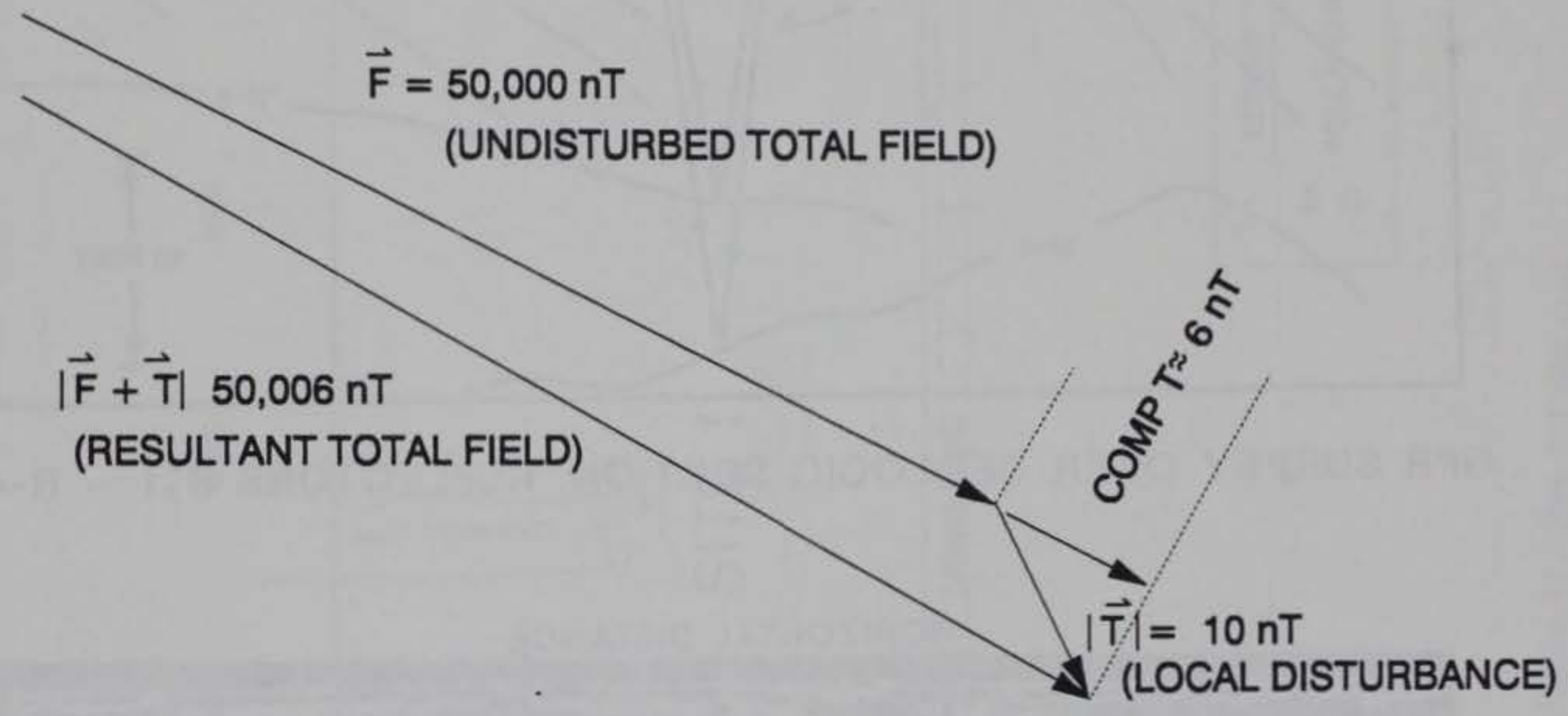

NOTE: NOT TO SCALE

Figure 9. Local perturbation of the total field vector (after Breiner 1973) 


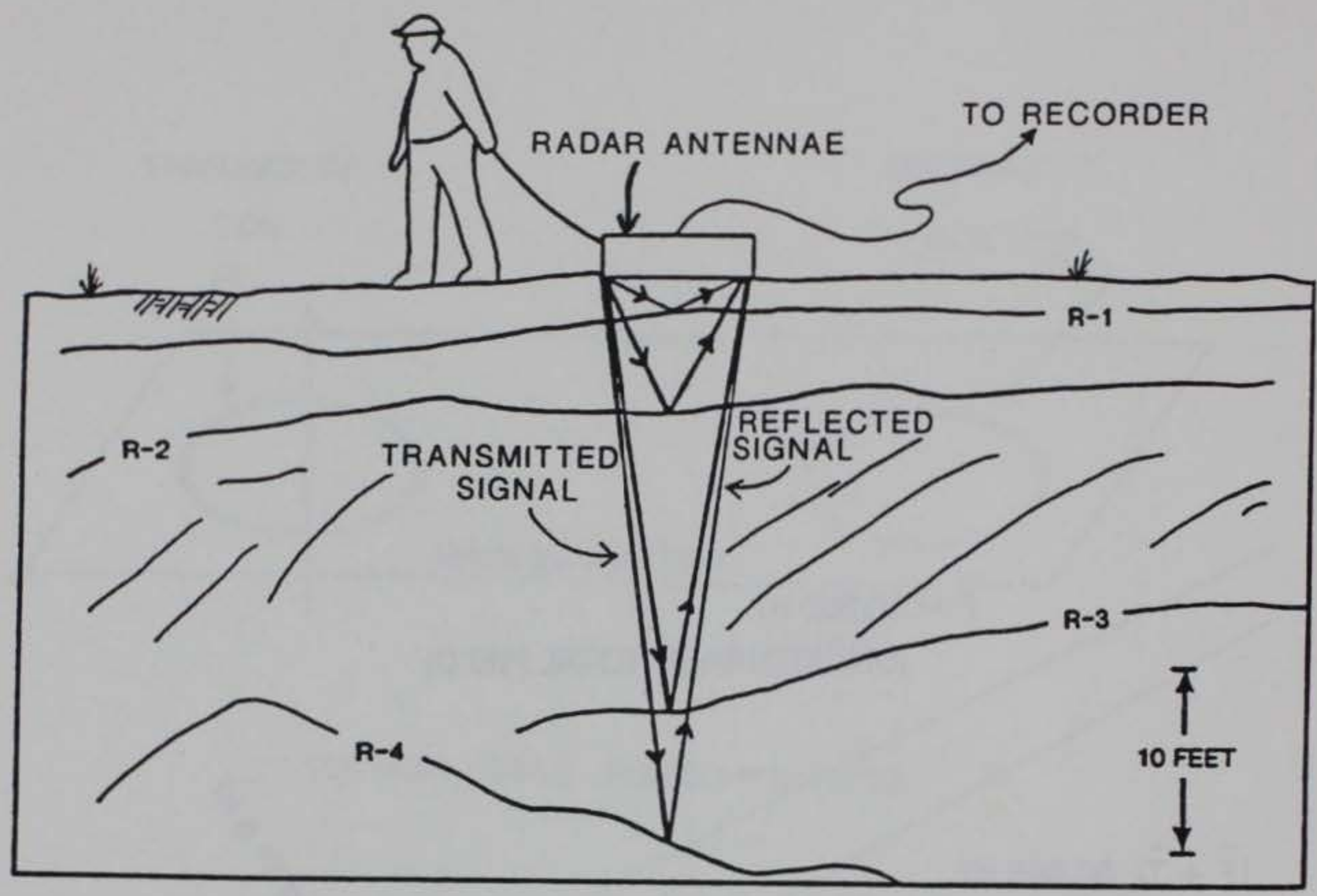

GPR SURVEY OVER GEOLOGIC SECTION, REFLECTORS R-1 -- R-4

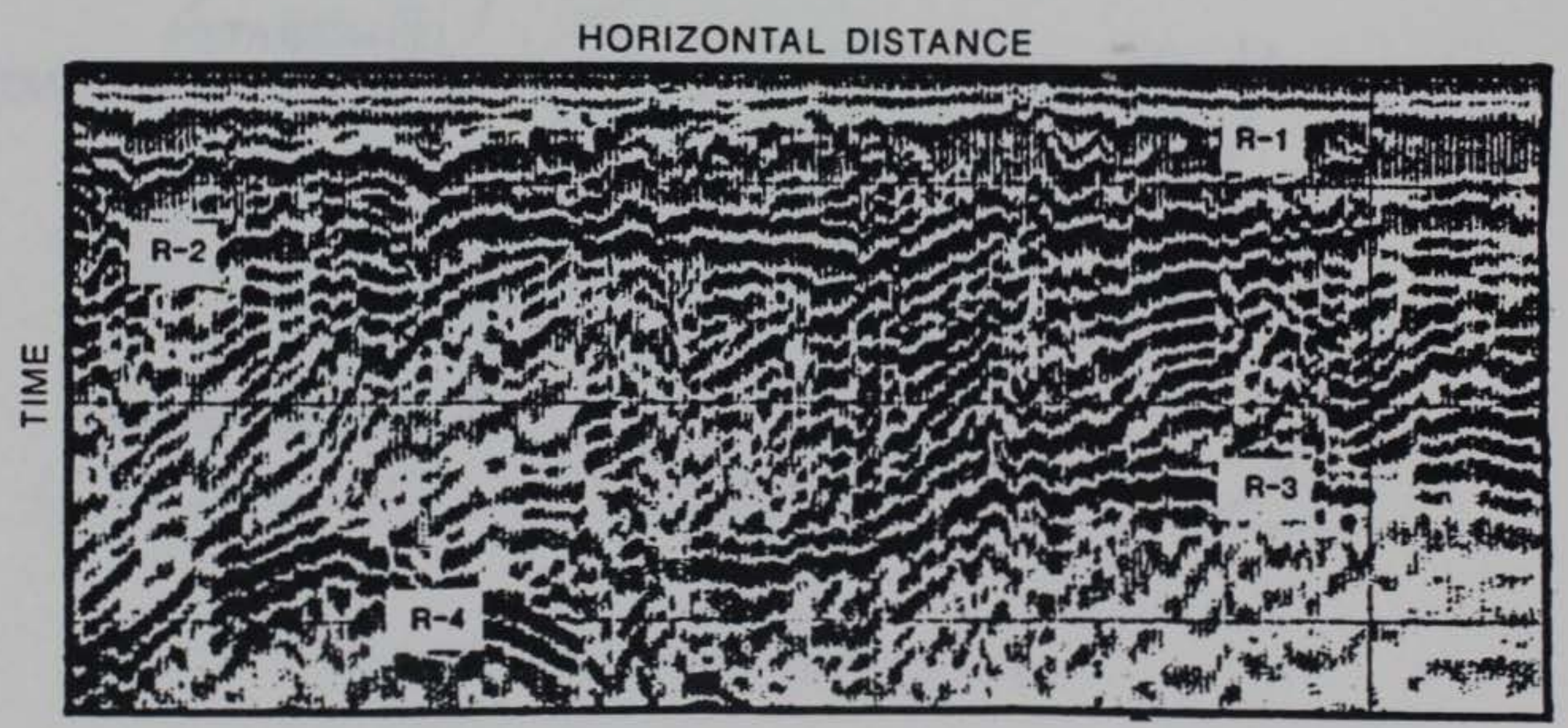

GRAPHIC RADAR RECORD FOR ABOVE SECTION

Figure 10. GPR survey concepts 


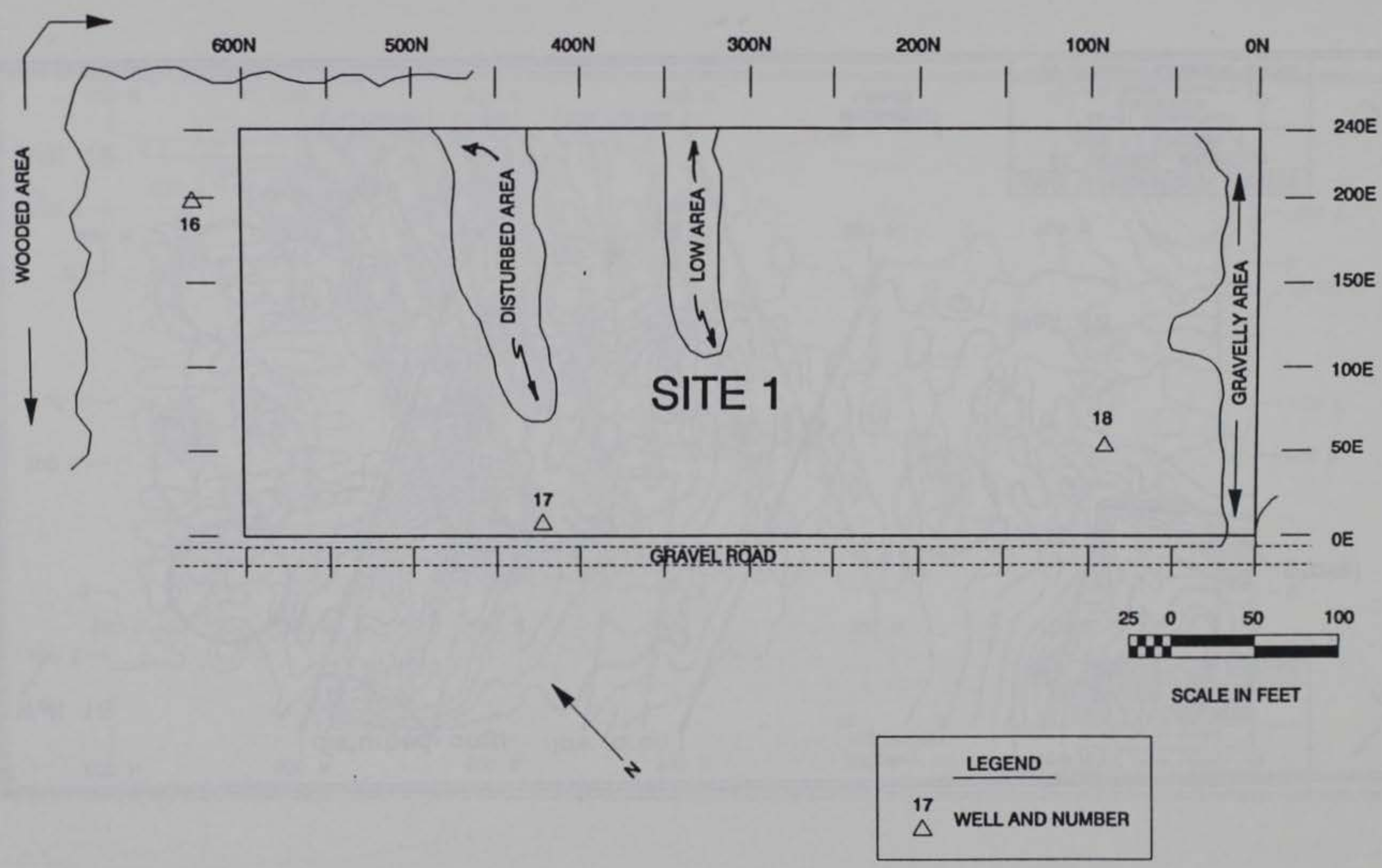

Figure 11. Site 1-1 site map 


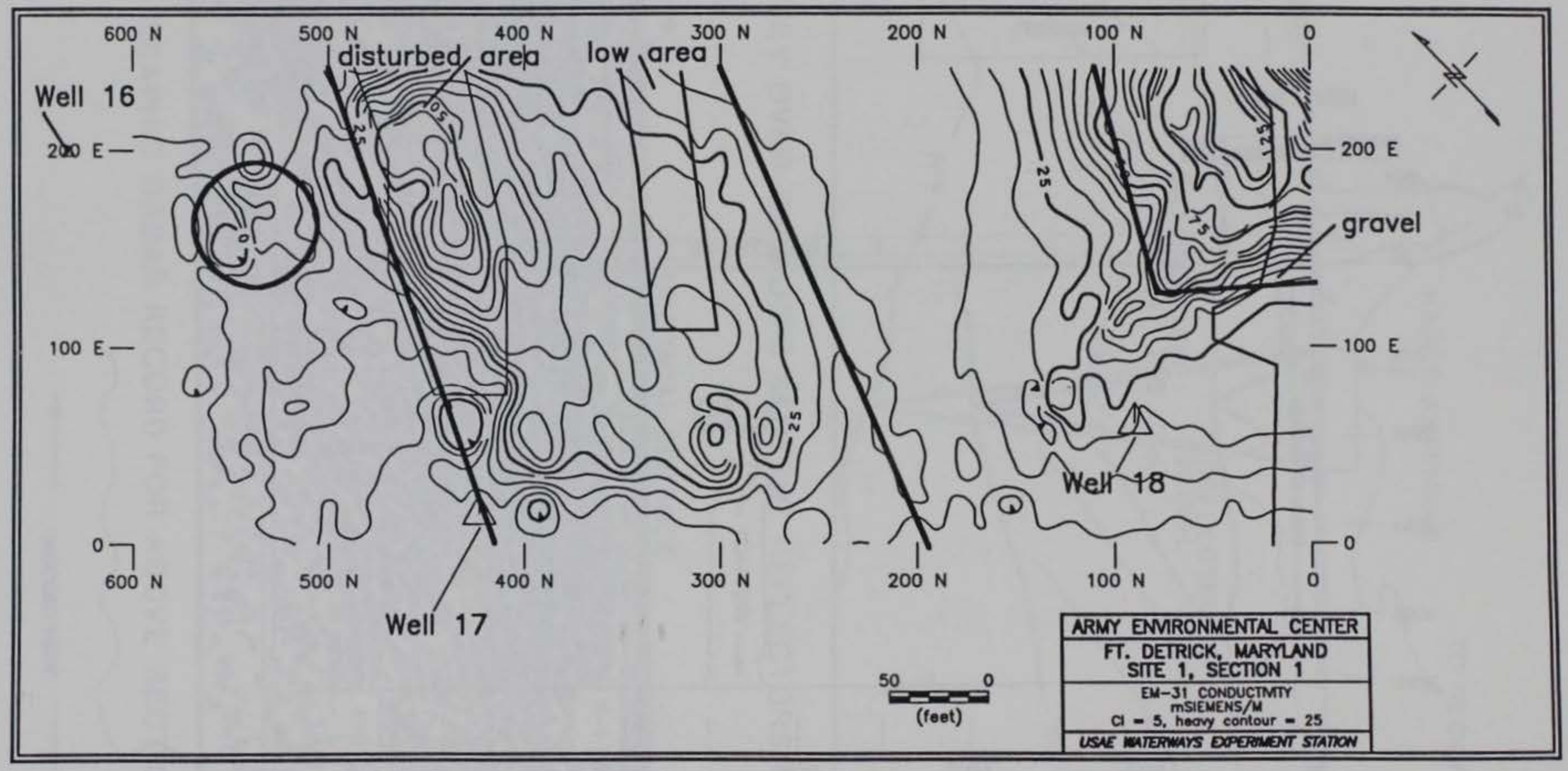

Figure 12. Site 1-1 conductivity survey results 


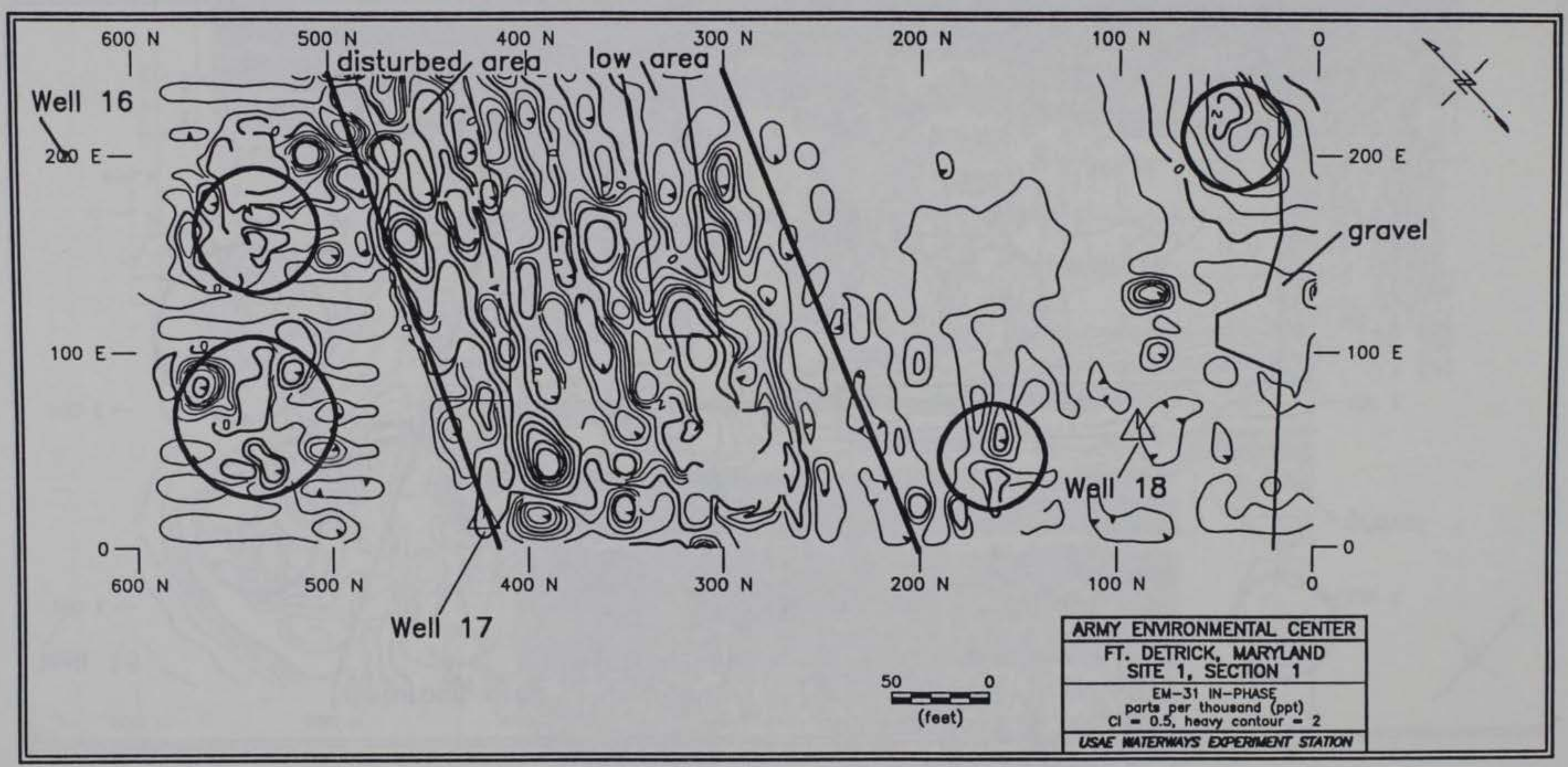

Figure 13. Site 1-1 in-phase survey results 


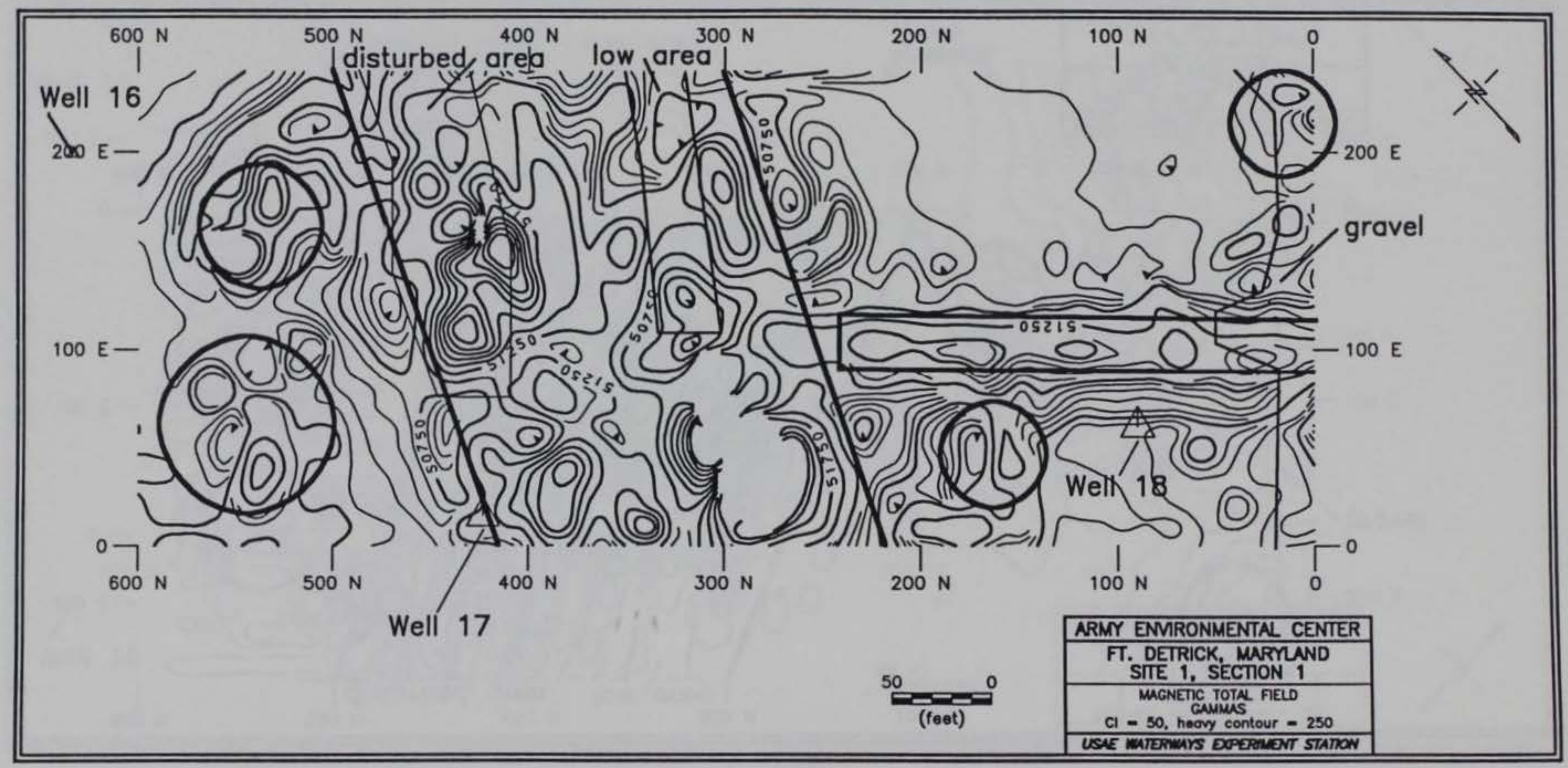

Figure 14. Site 1-1 total magnetic field survey results 

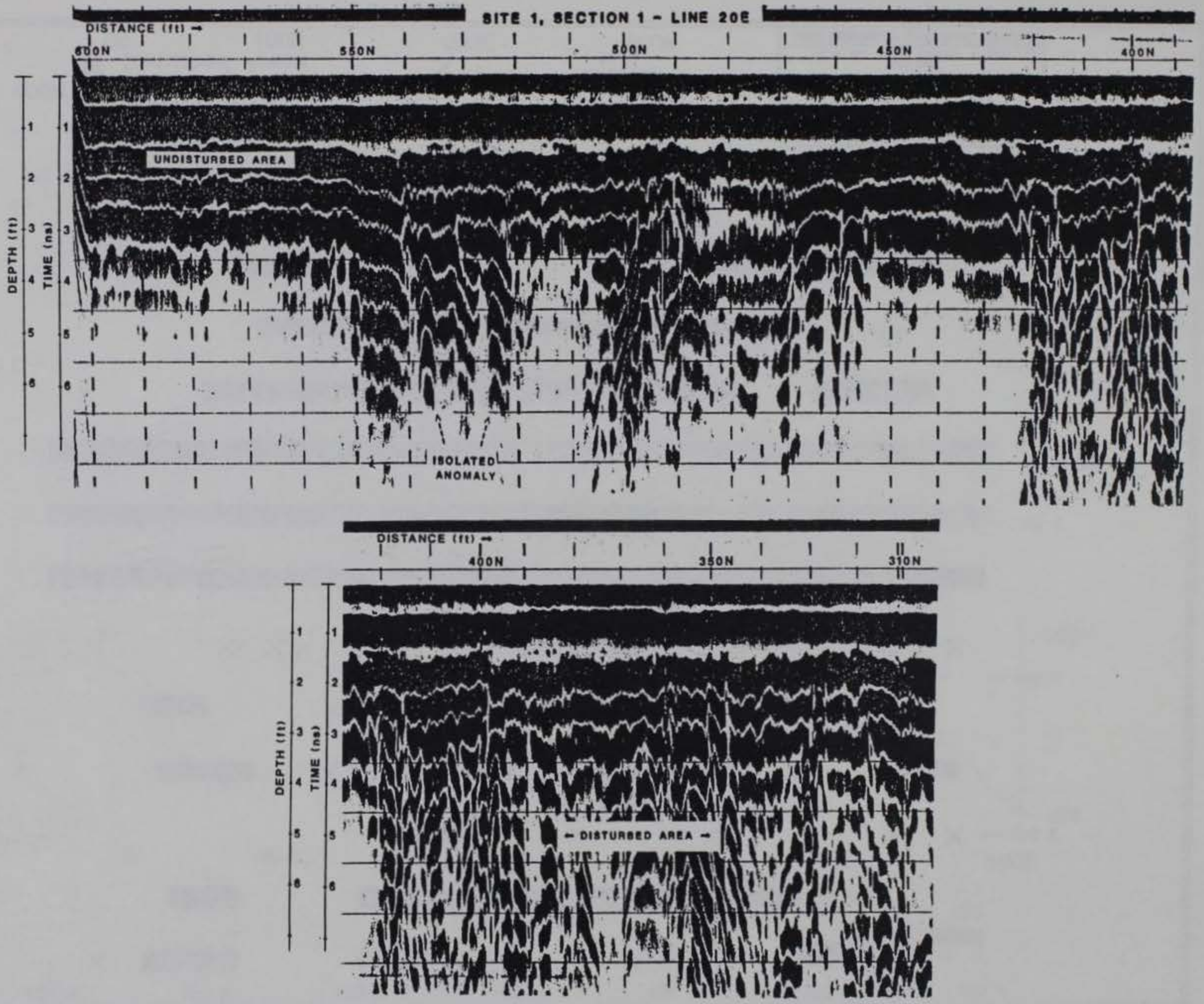

Figure 15. Example of GPR results 


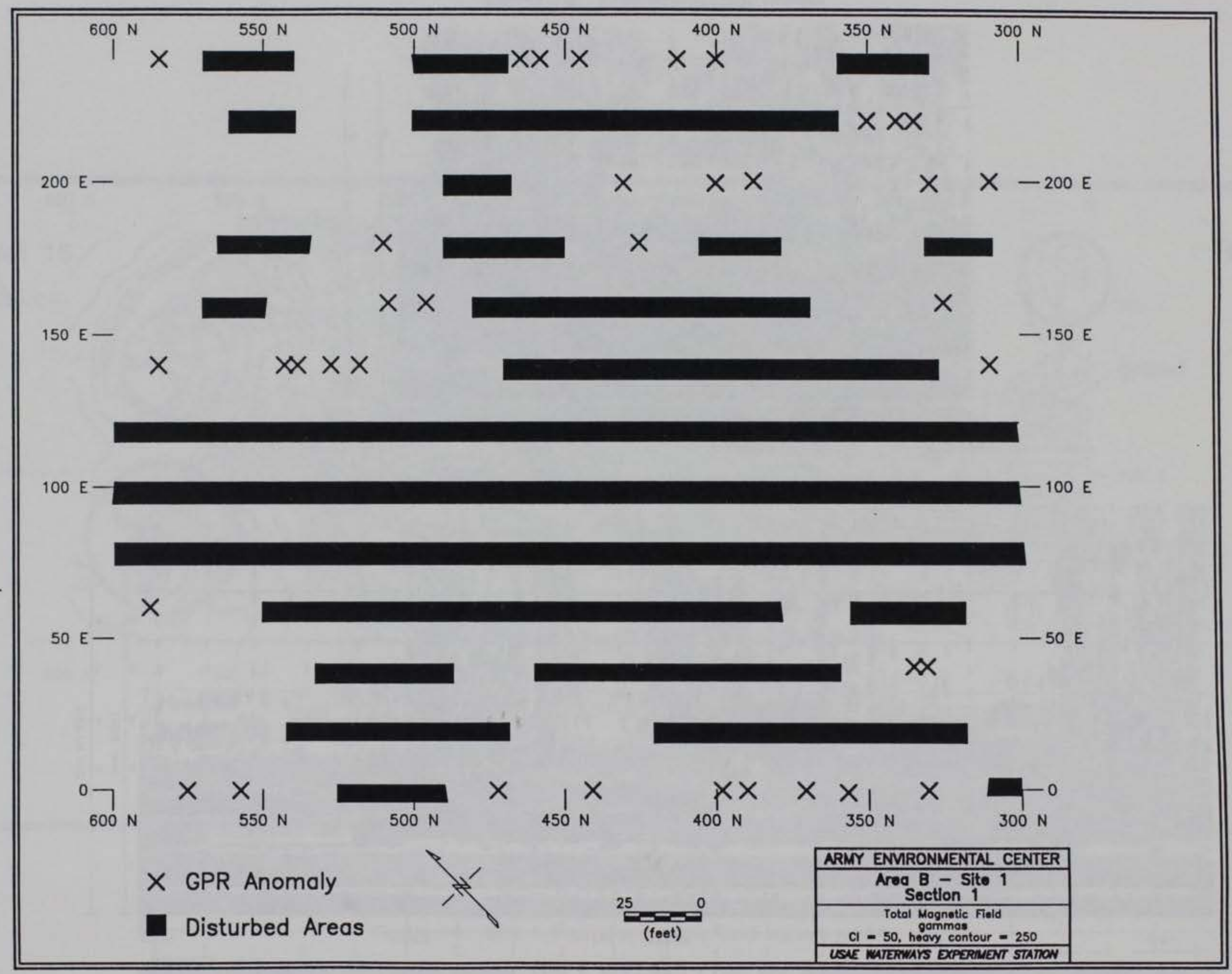

Figure 16. Site 1-1 GPR survey results 


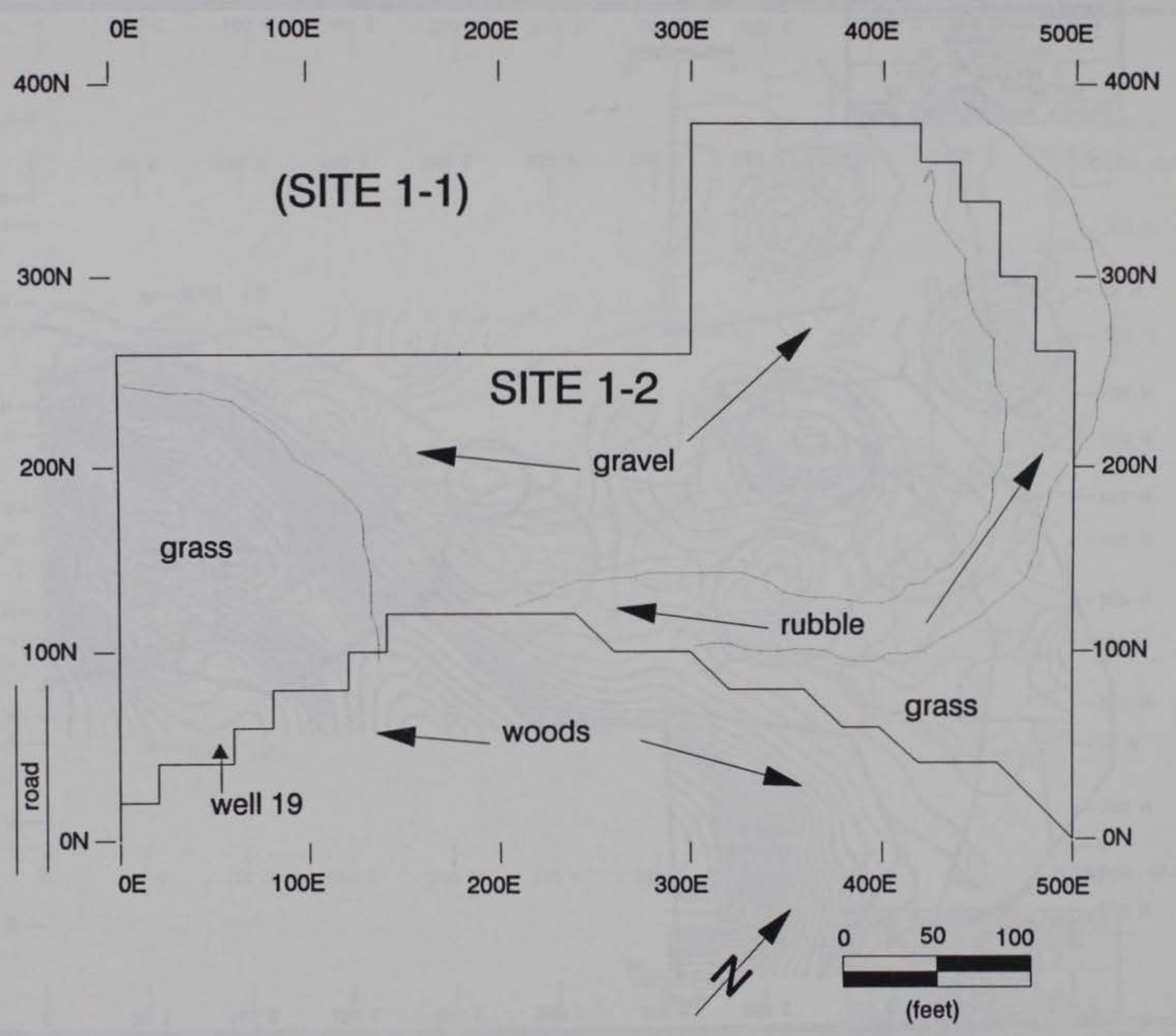

Figure 17. Site 1-2 site map 


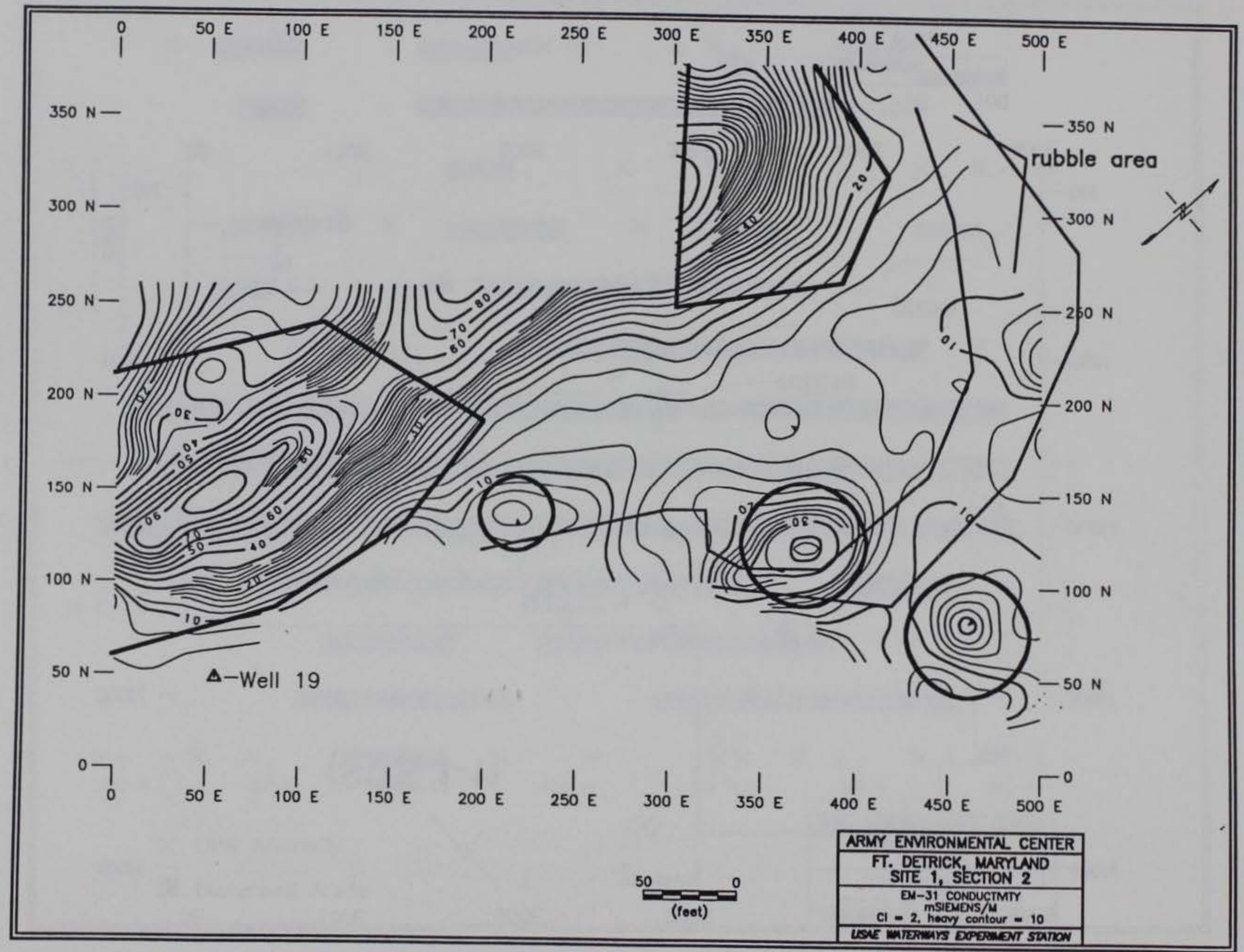

Figure 18 . Site 1-2 conductivity results 


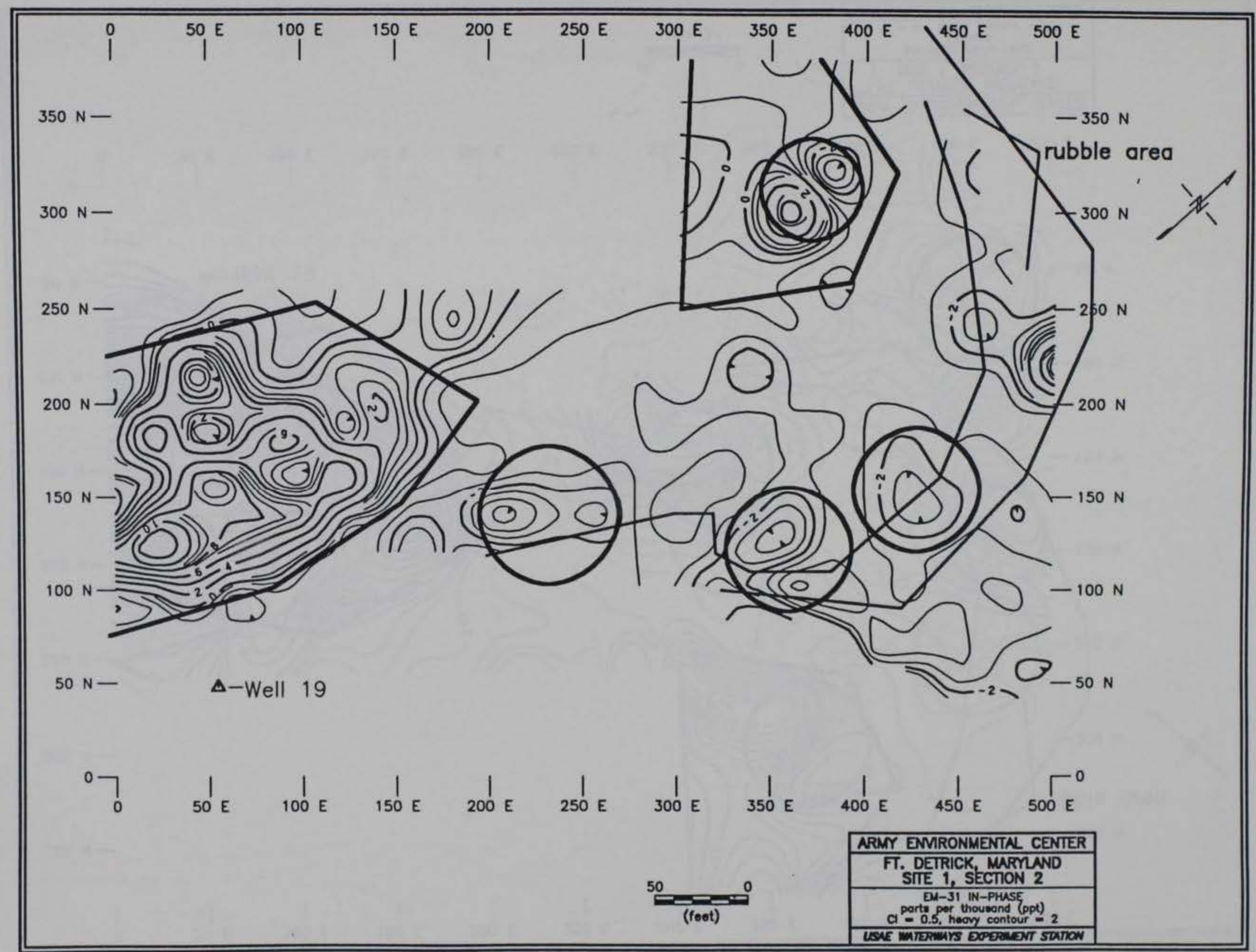

Figure 19. Site 1-2 in-phase results 


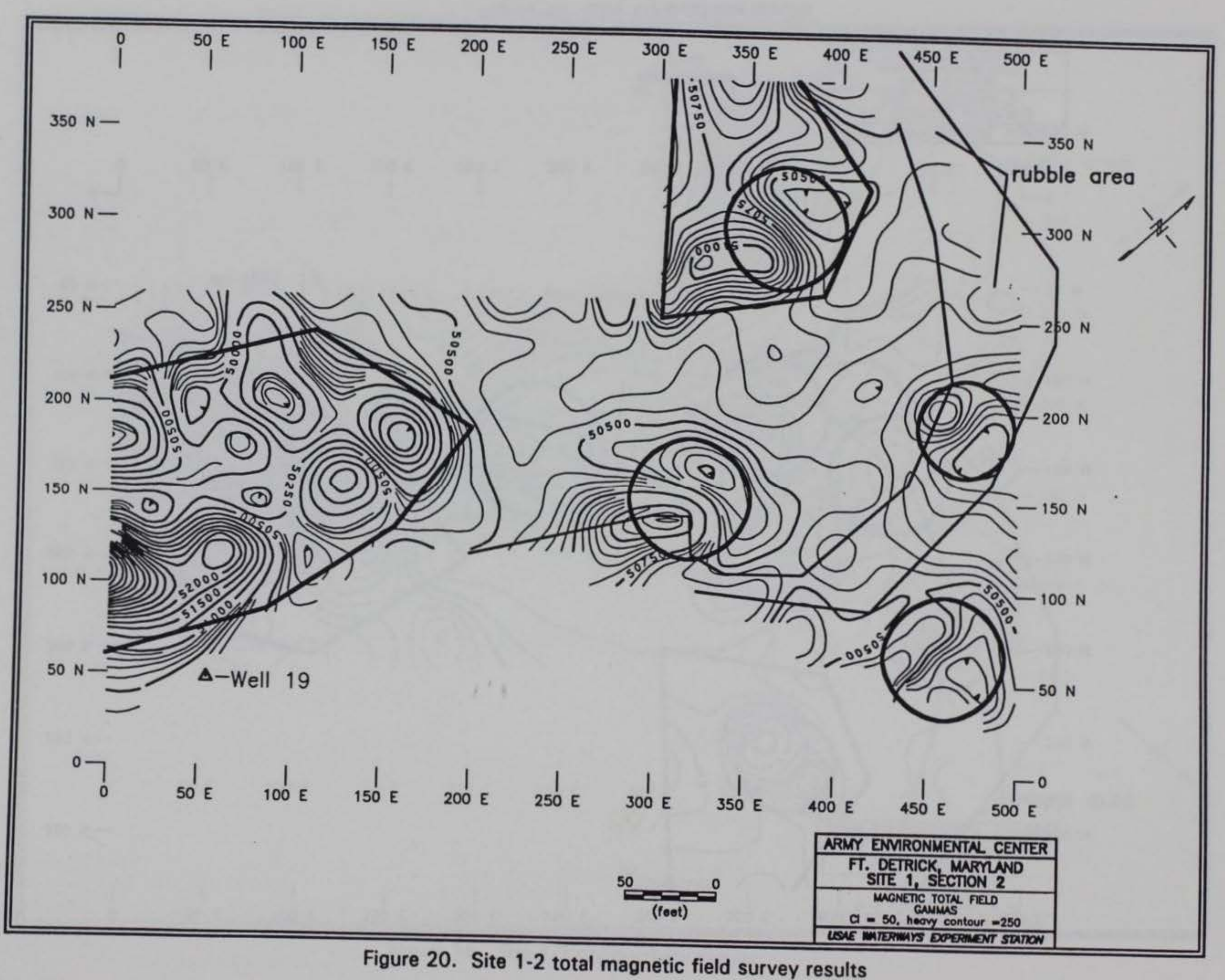




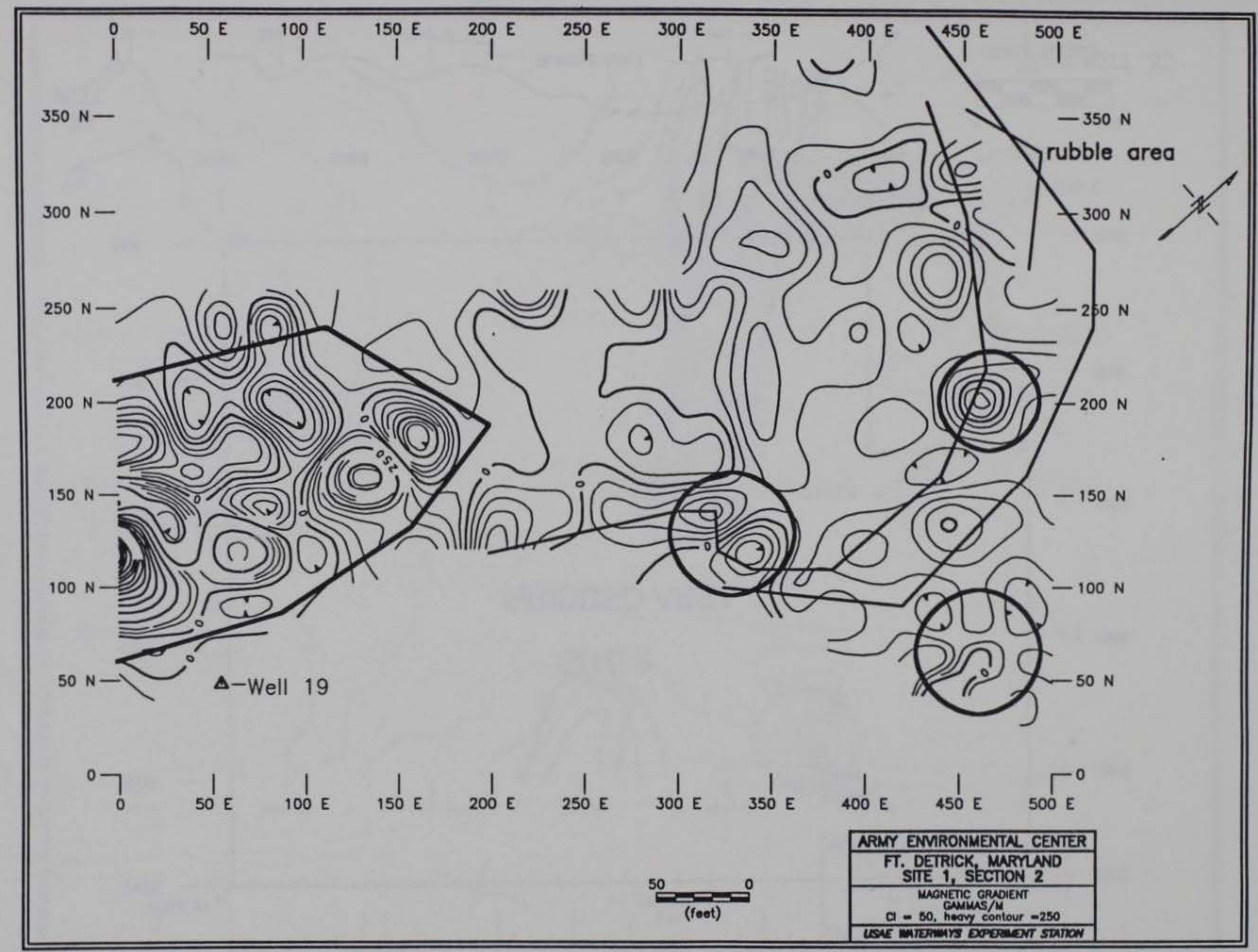

Figure 21. Site 1-2 magnetic gradient survey results 


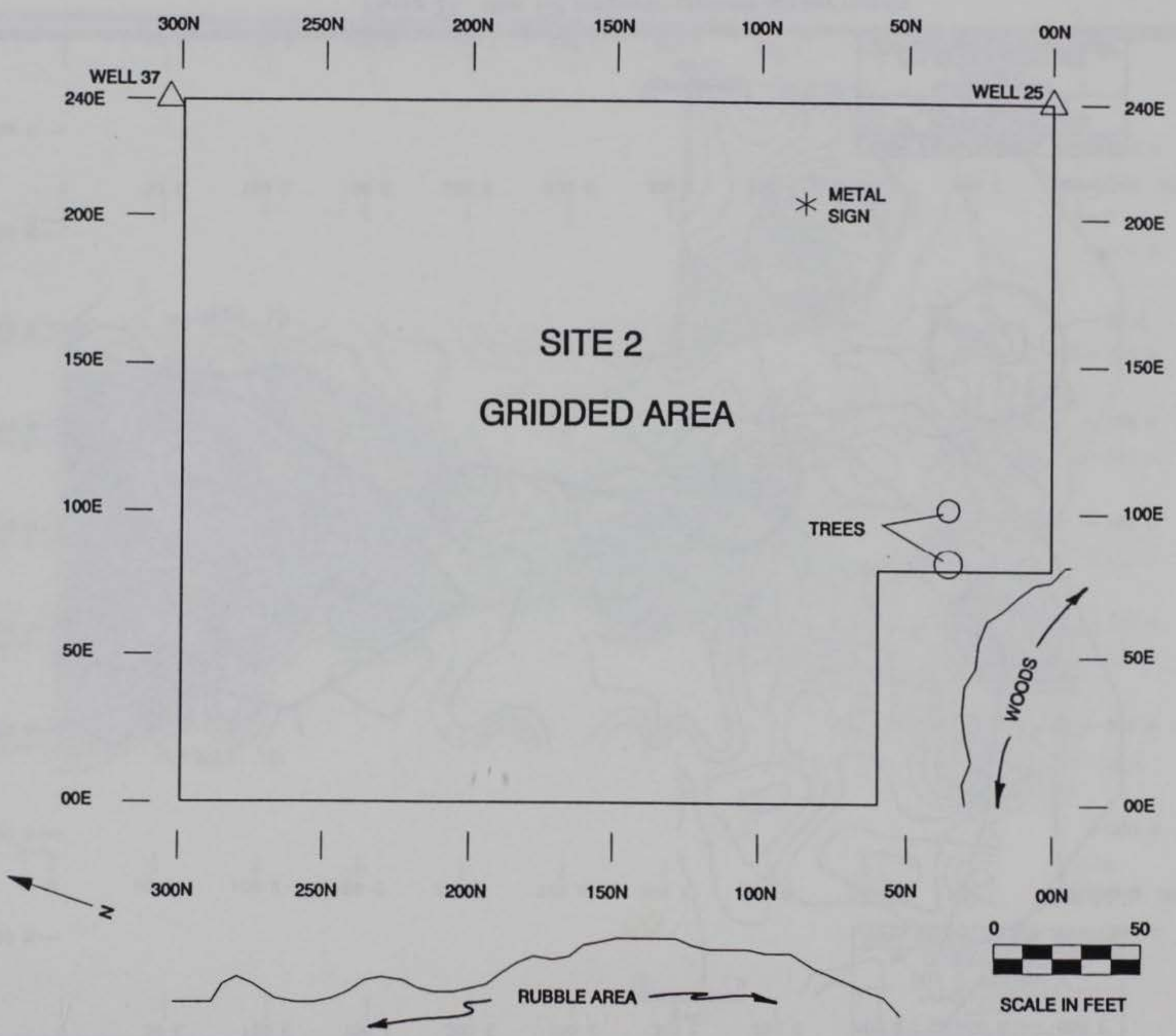

Figure 22. Site 2-1 site map 


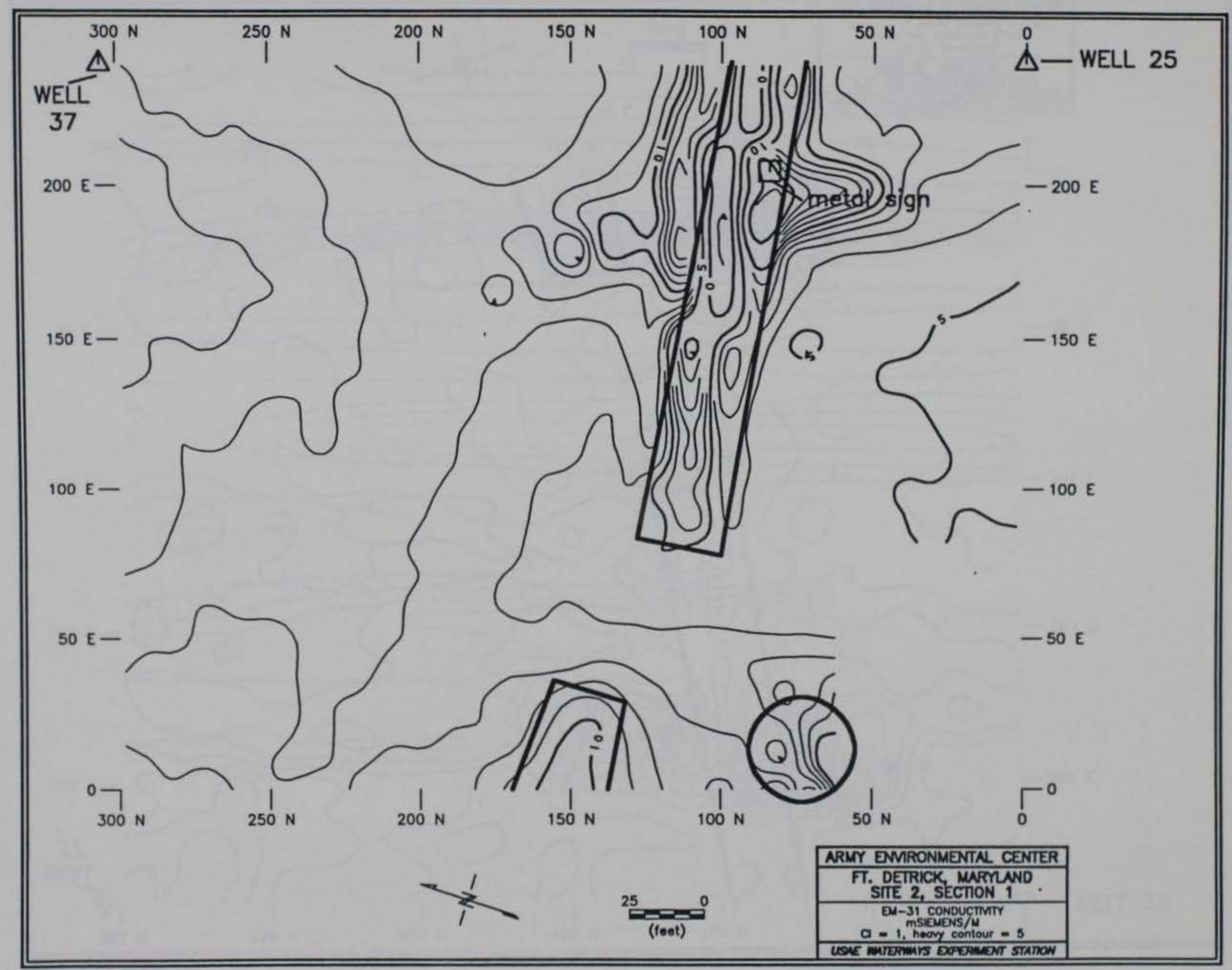

Figure 23. Site 2-1 conductivity survey results 


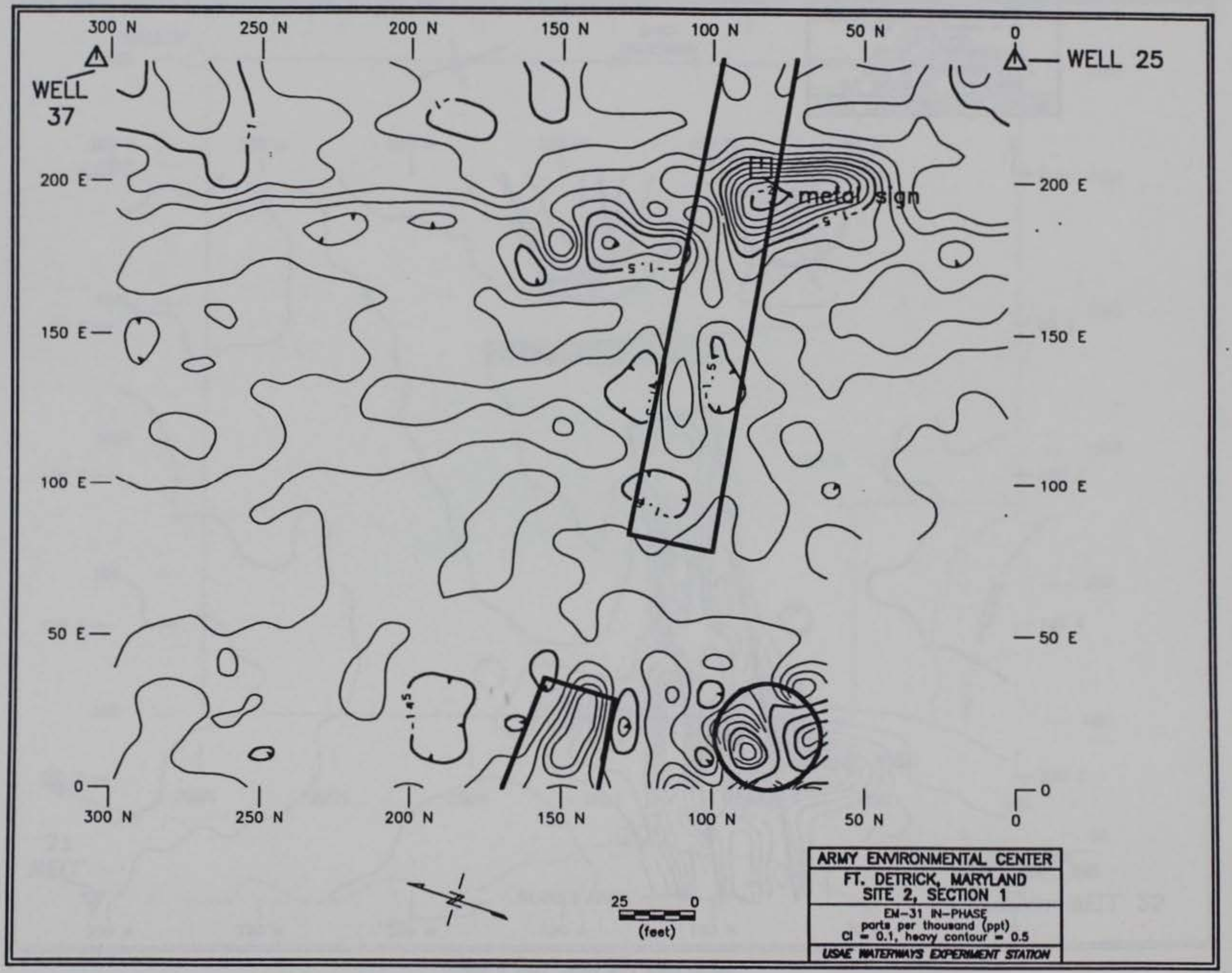

Figure 24. Site 2-1 in-phase survey results 


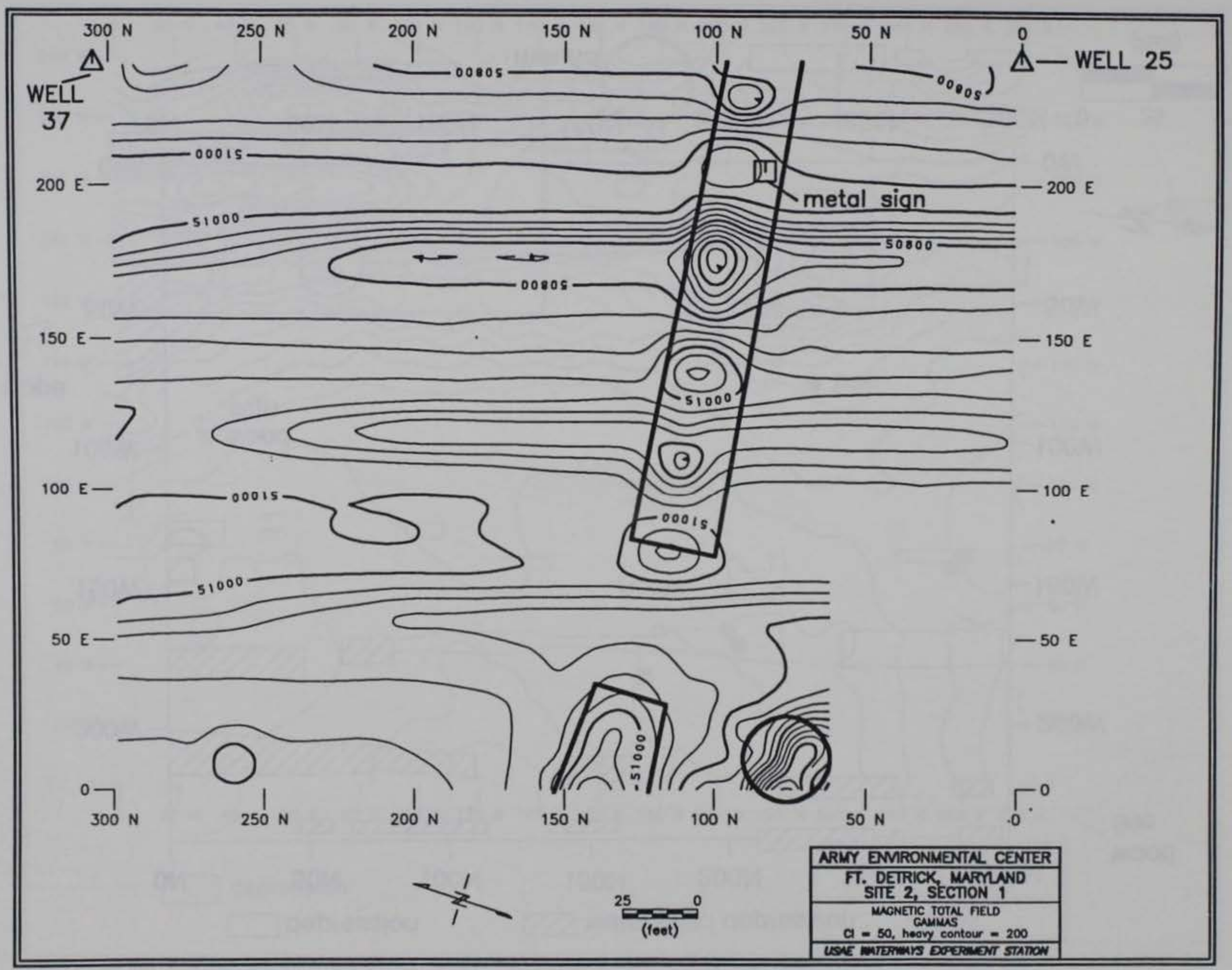

Figure 25. Site 2-1 total magnetic field survey results 


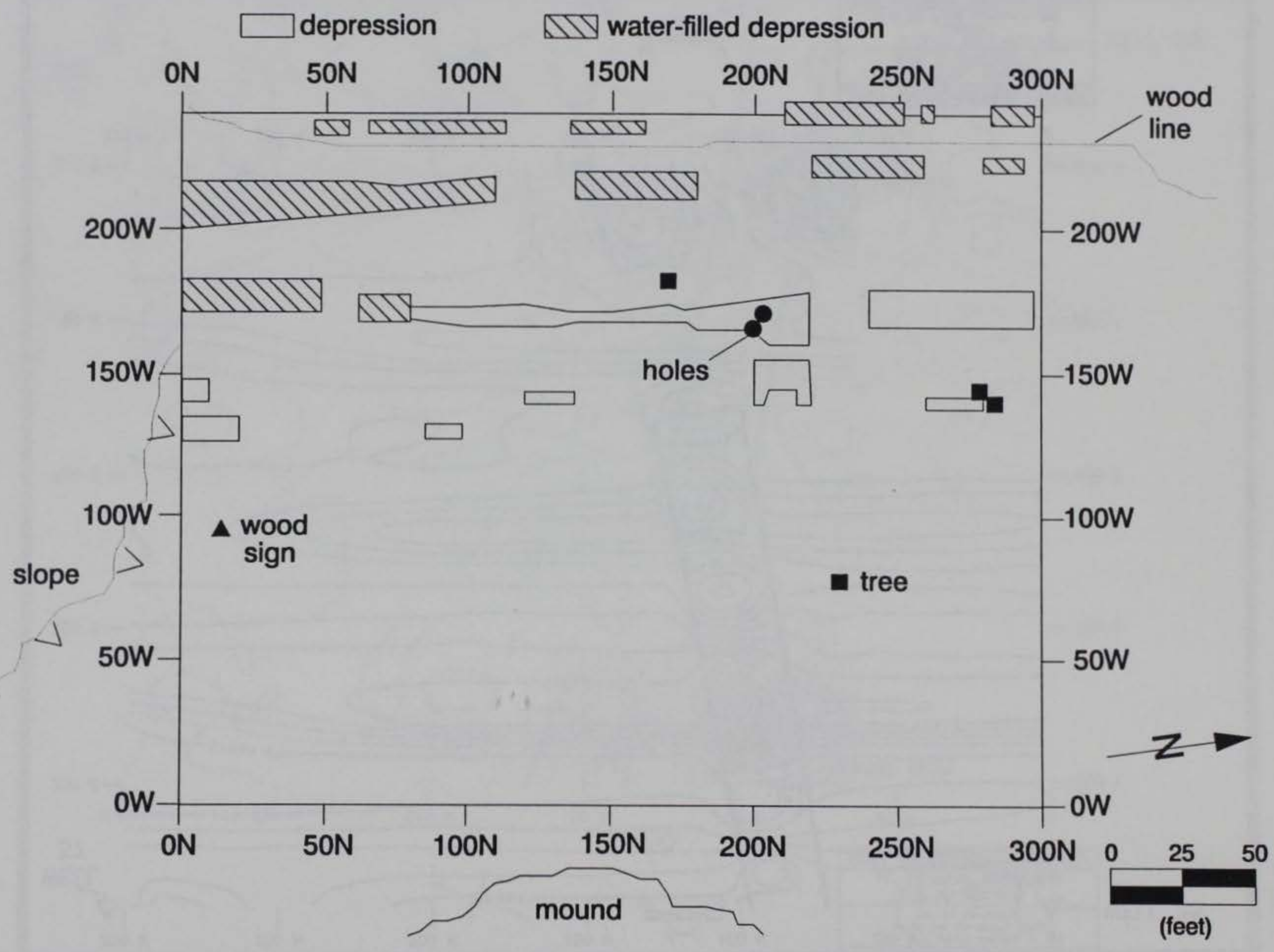

Figure 26. Site 2-2 site map 


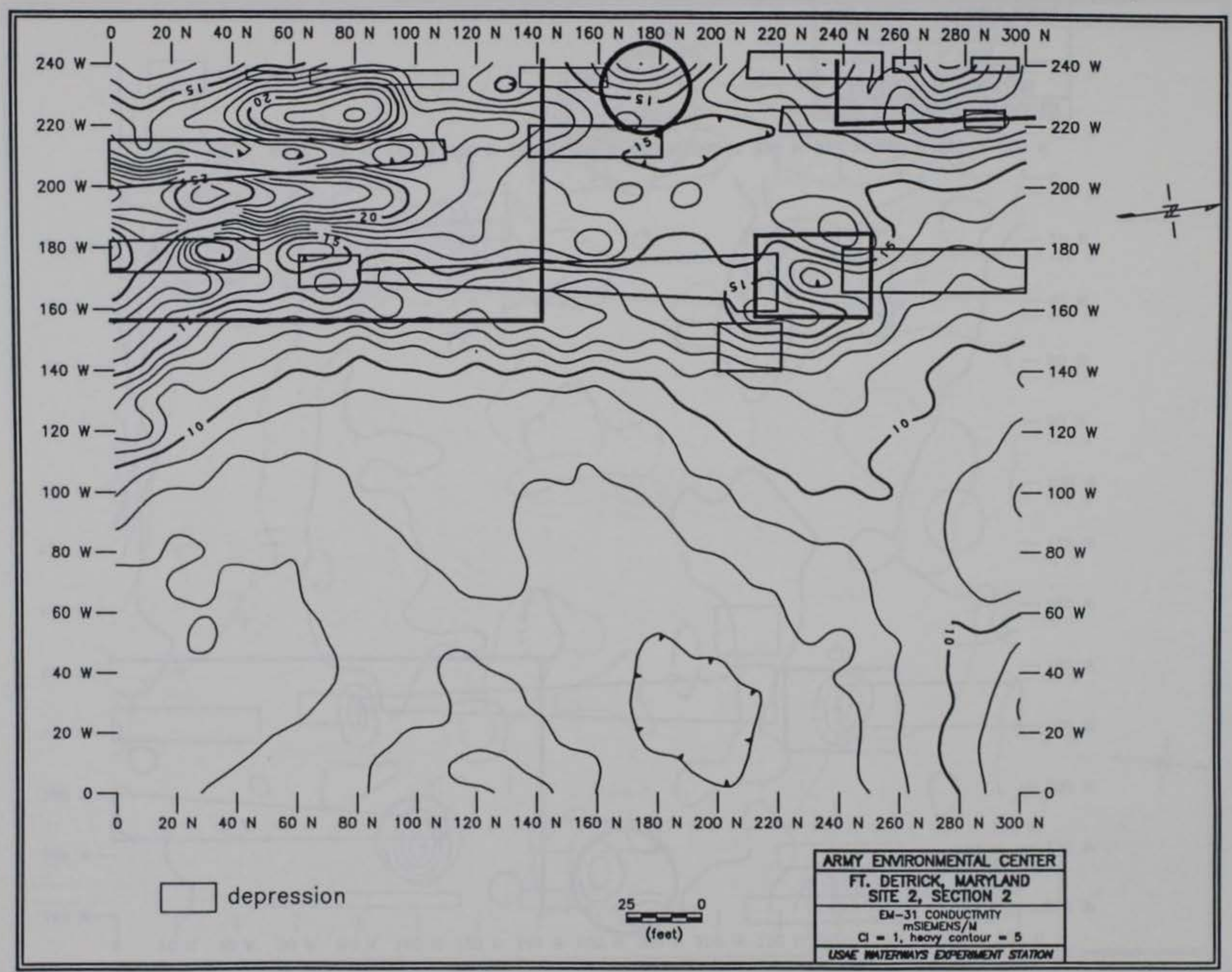

Figure 27. Site $2-2$ conductivity results 


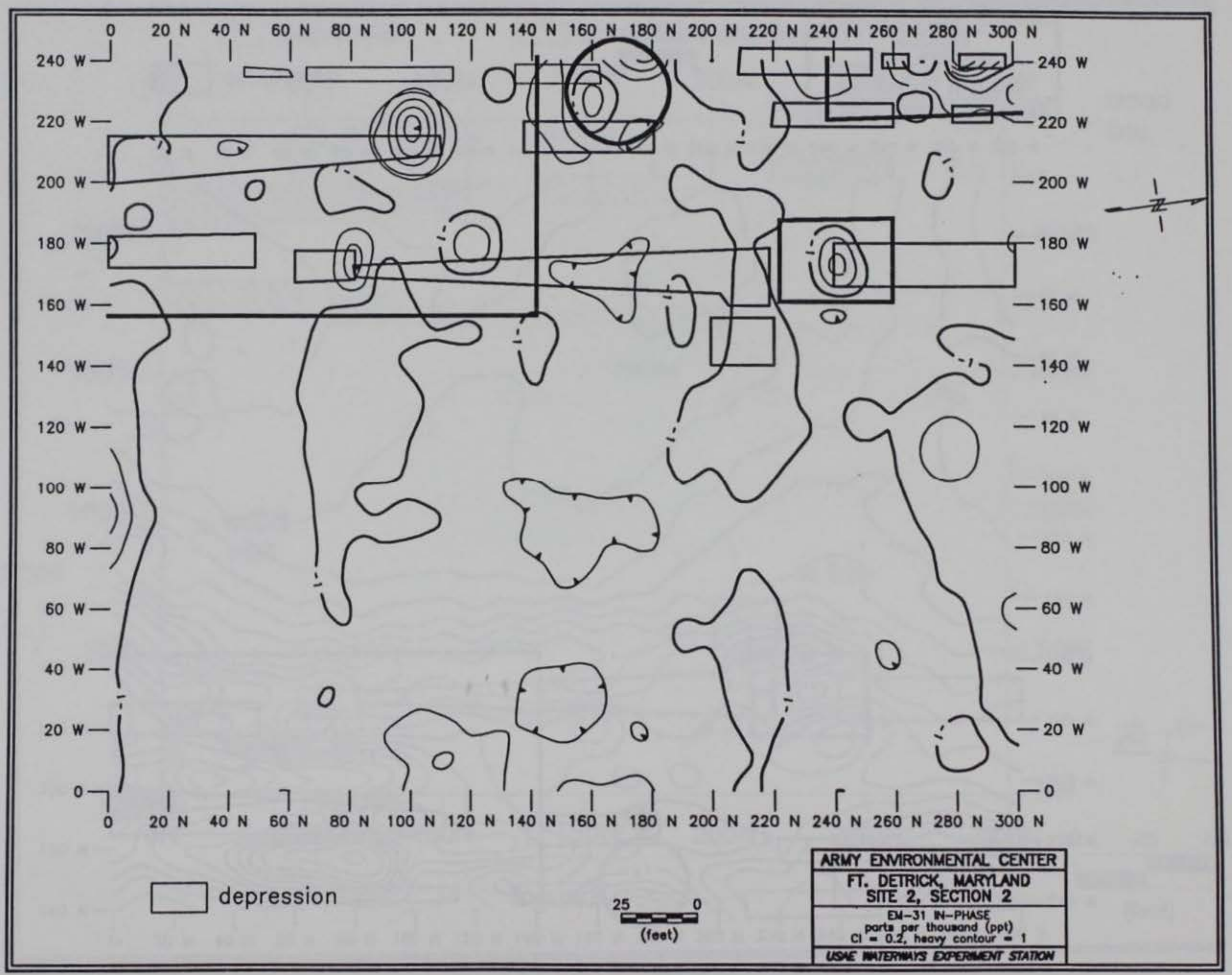

Figure 28. Site 2-2 in-phase results 


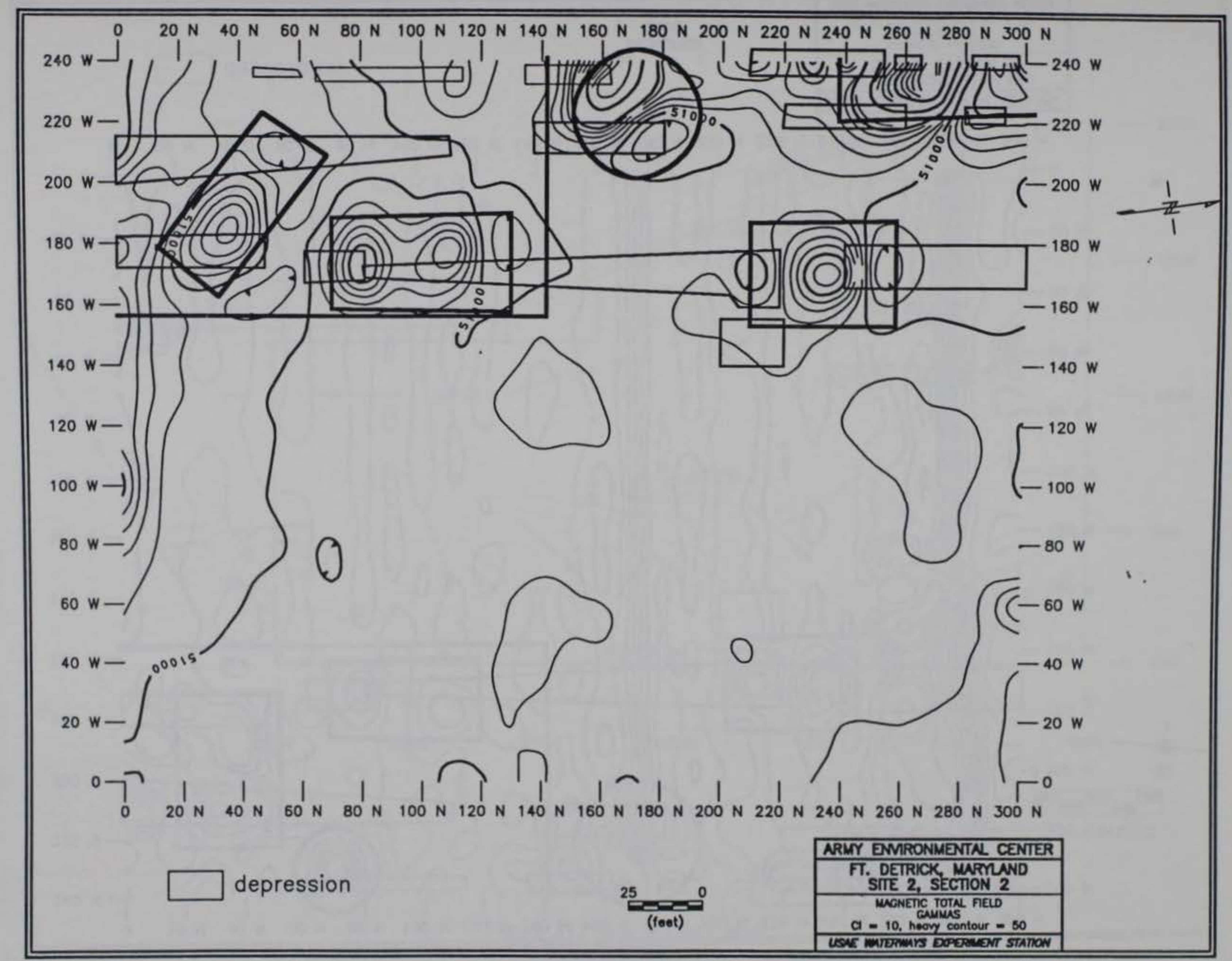

Figure 29. Site 2-2 total magnetic field survey results 


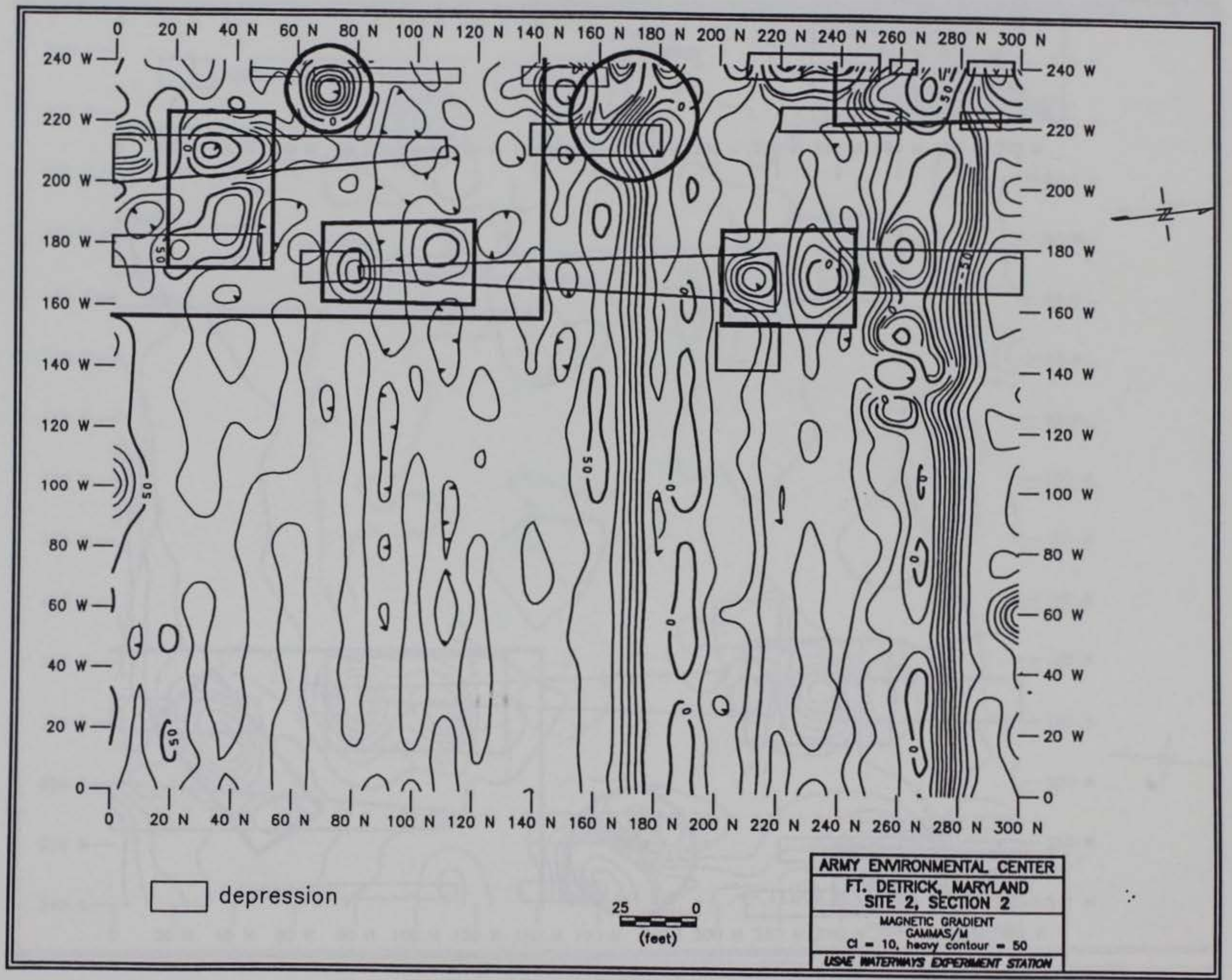

Figure 30. Site 2-2 magnetic gradient survey results 


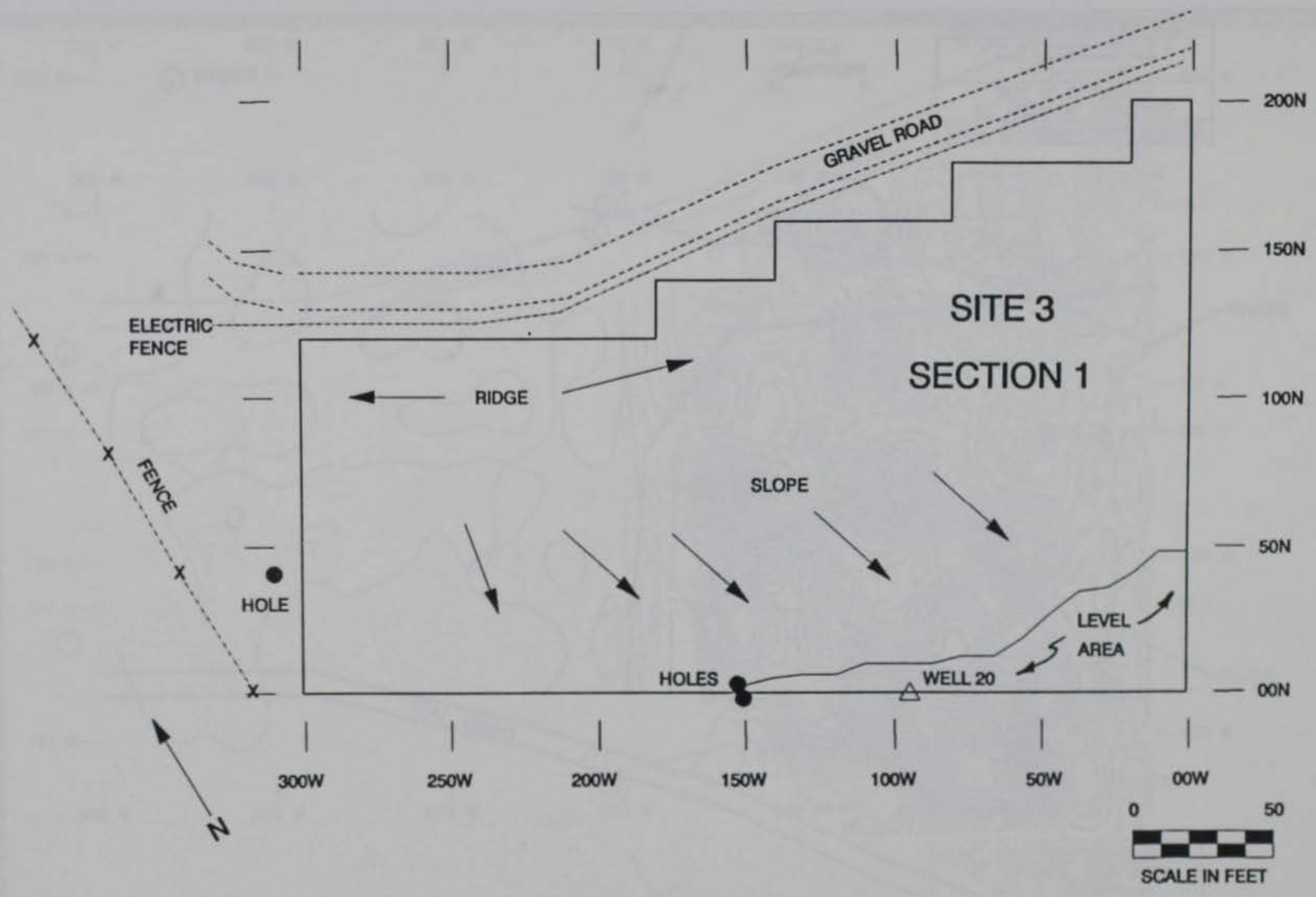

Figure 31. Site 3-1 site map 


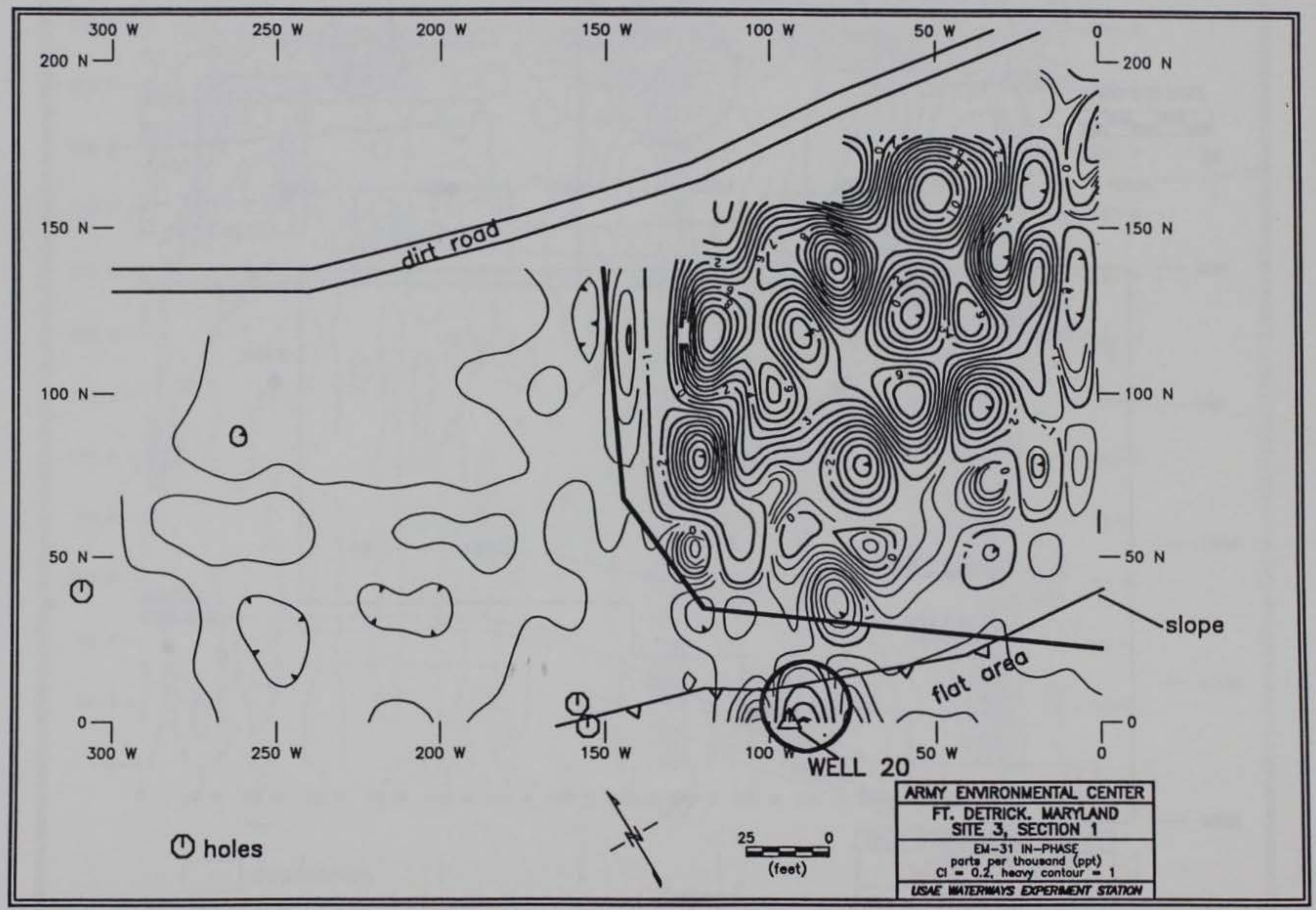

Figure 32 . Site 3-1 conductivity survey results 


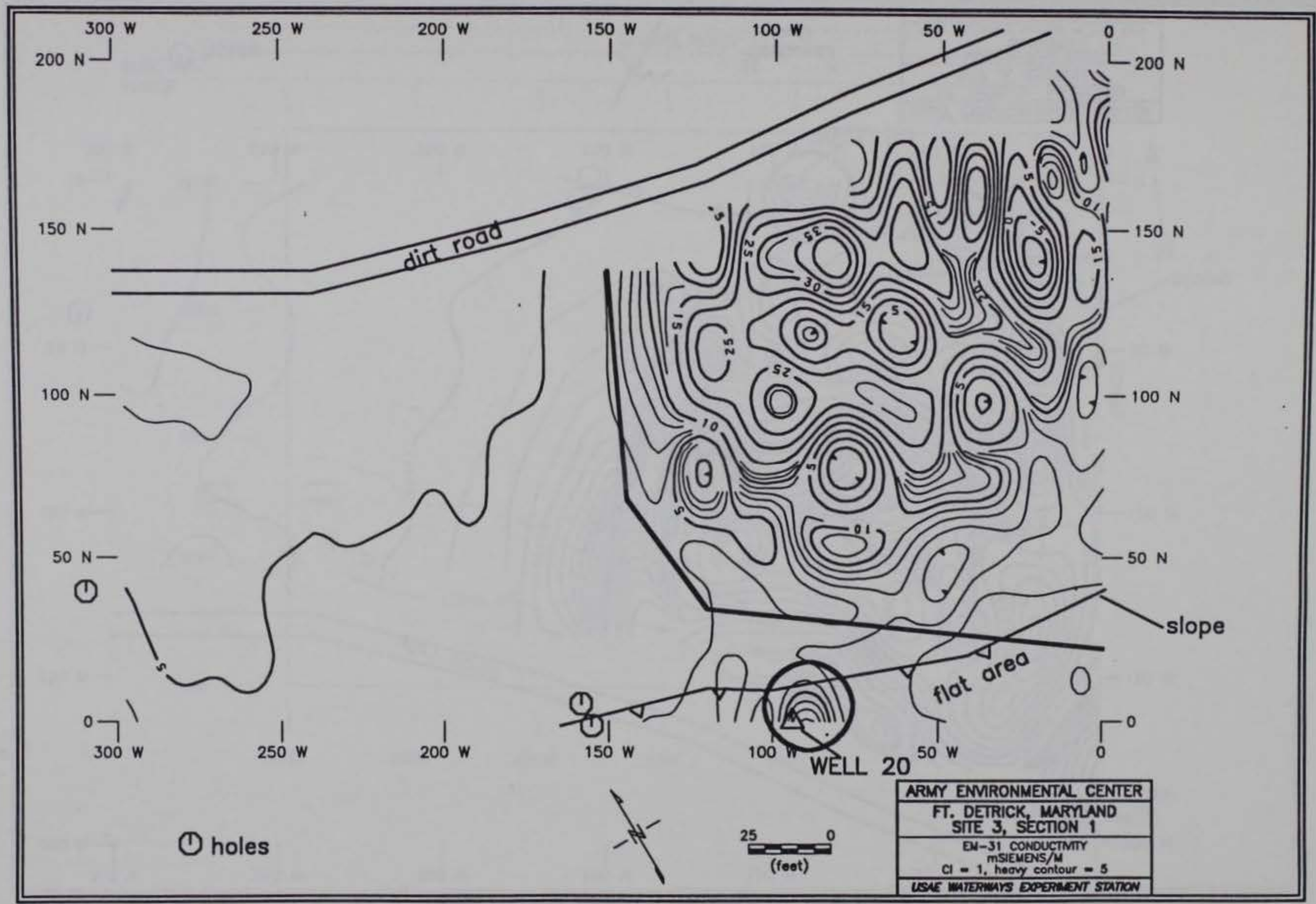

Figure 33. Site 3-1 in-phase survey results 


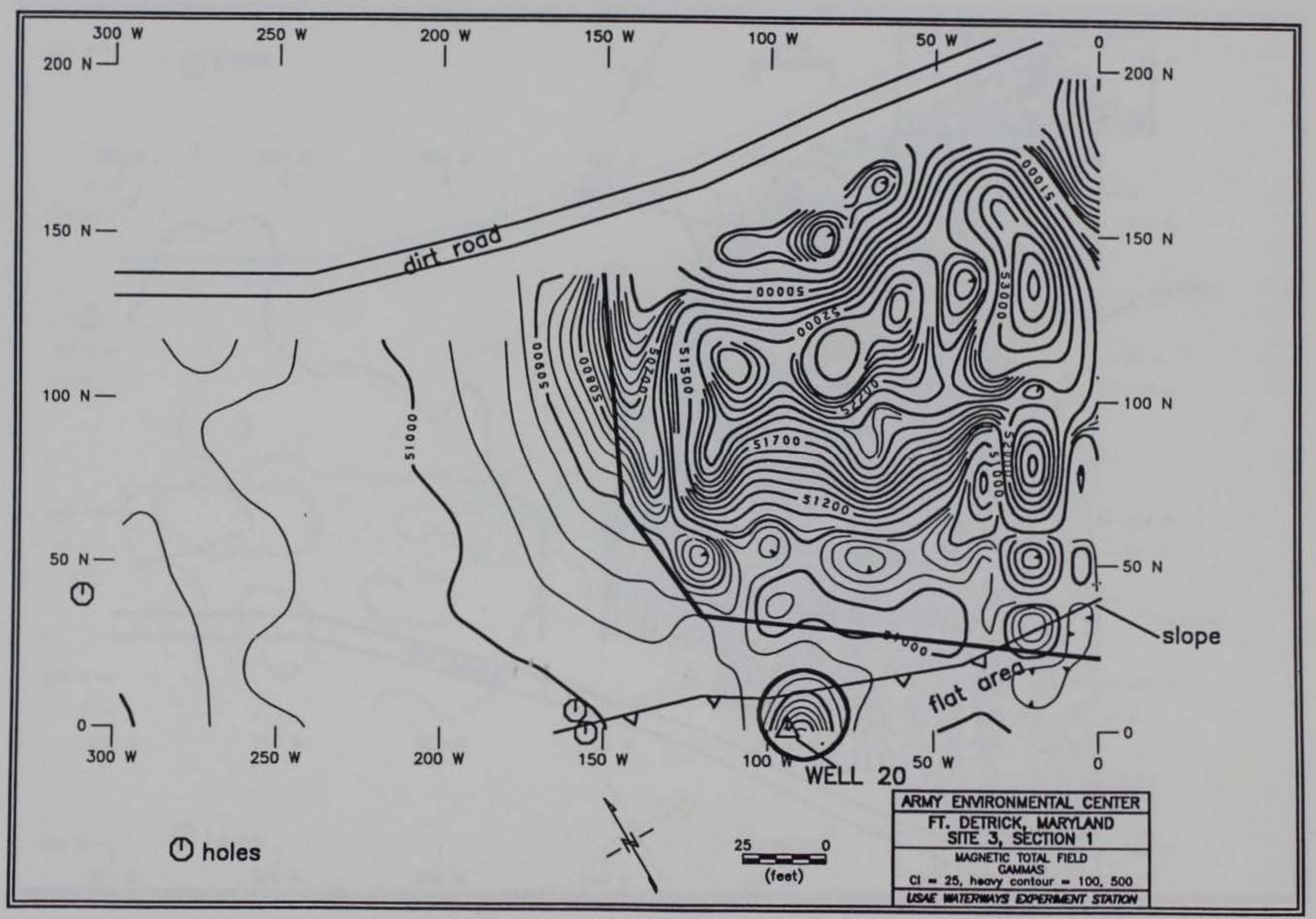

Figure 34. Site 3-1 total magnetic field survey results 


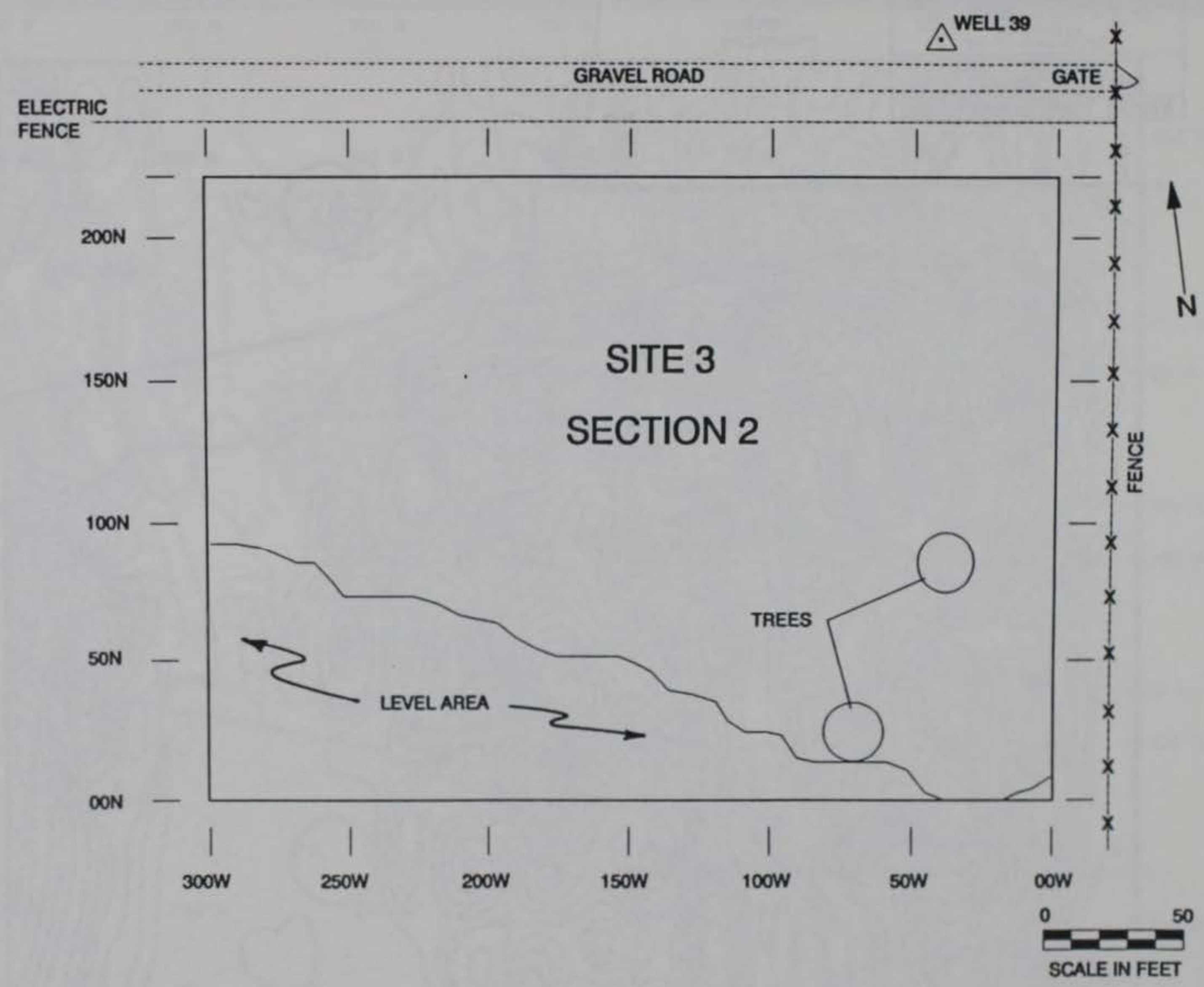

Figure 35. Site 3-2 site map 


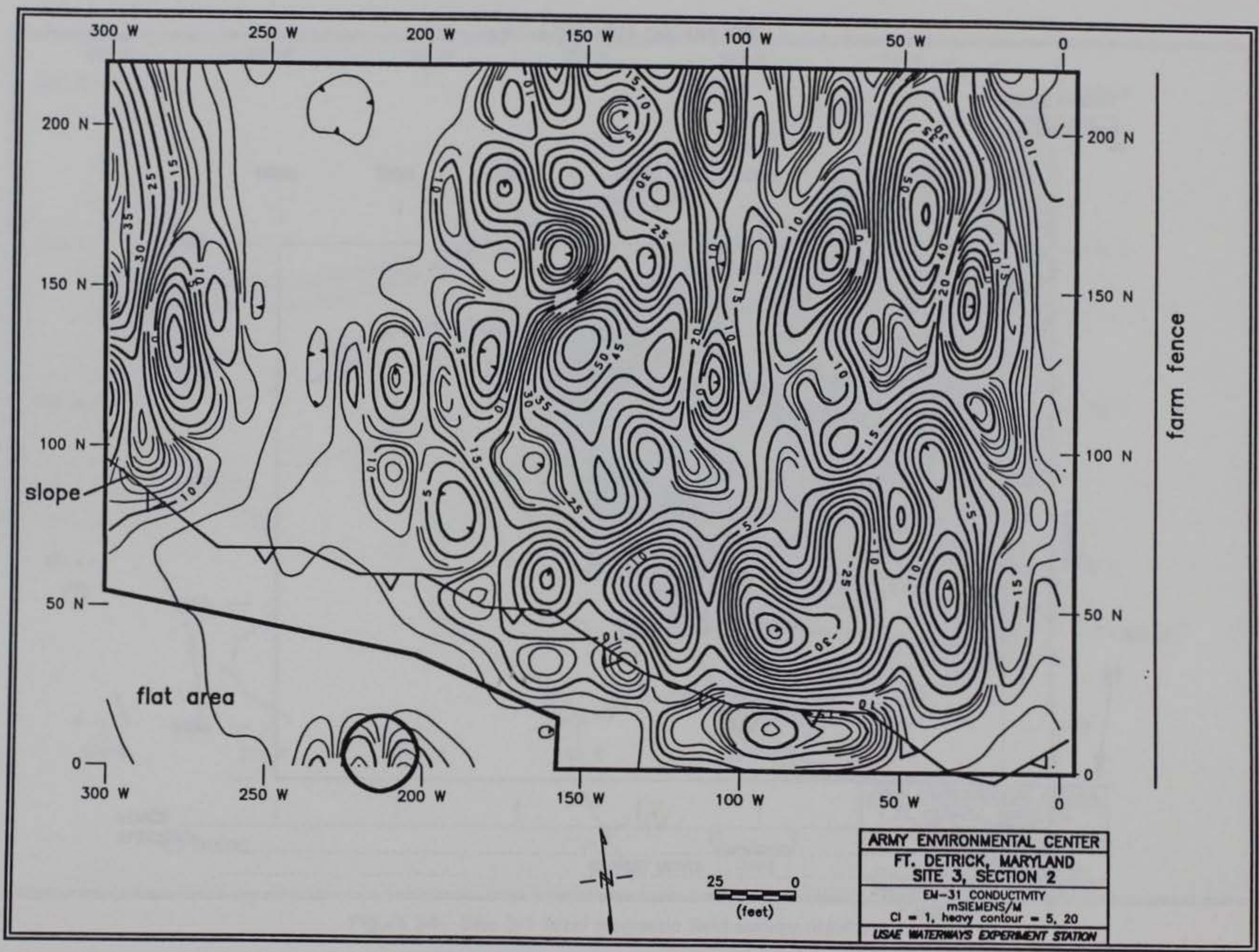

Figure 36 . Site $3-2$ conductivity results 


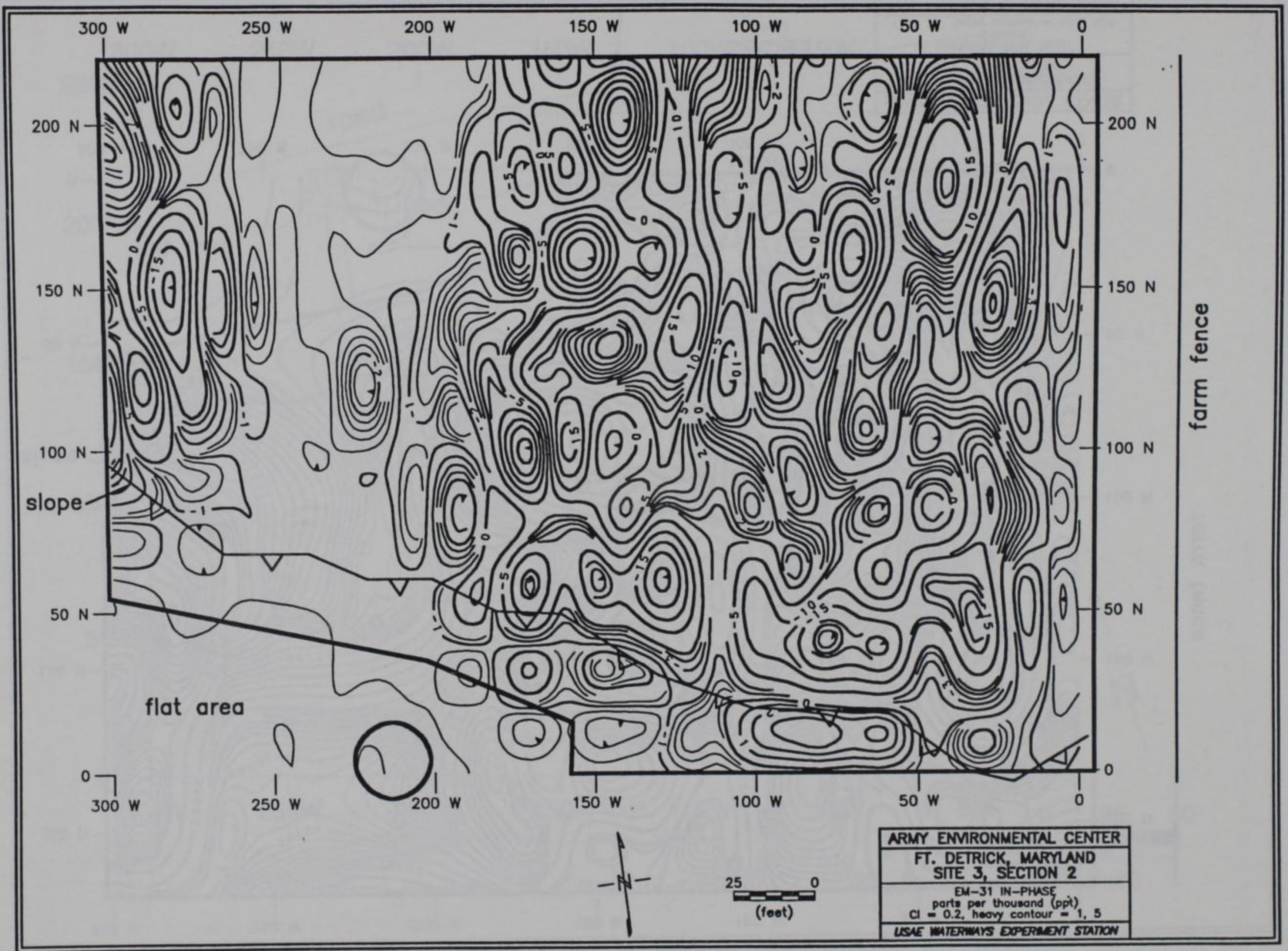

Figure 37 . Site $3-2$ in-phase results 


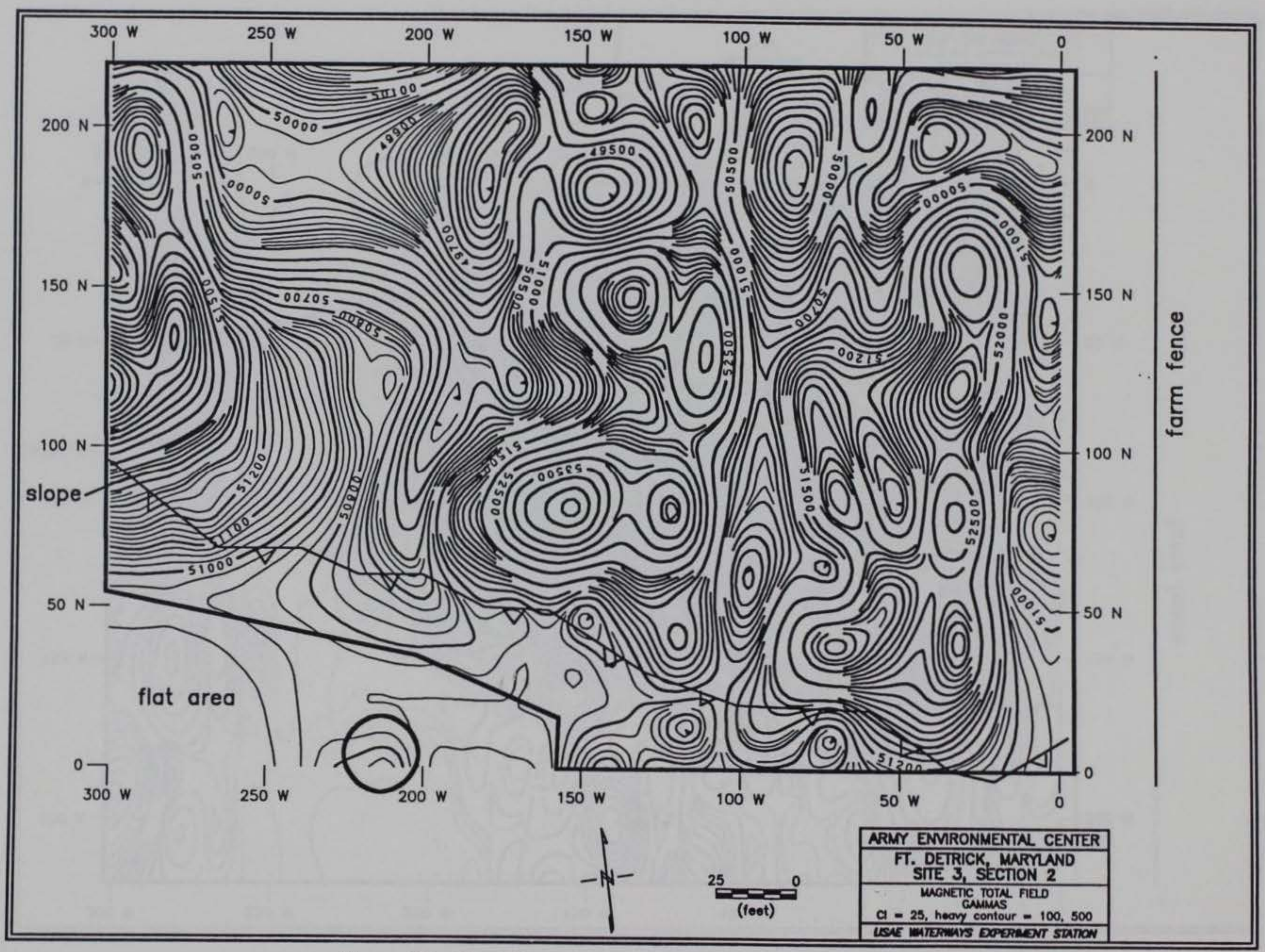

Figure 38. Site 3-2 total magnetic field survey results 


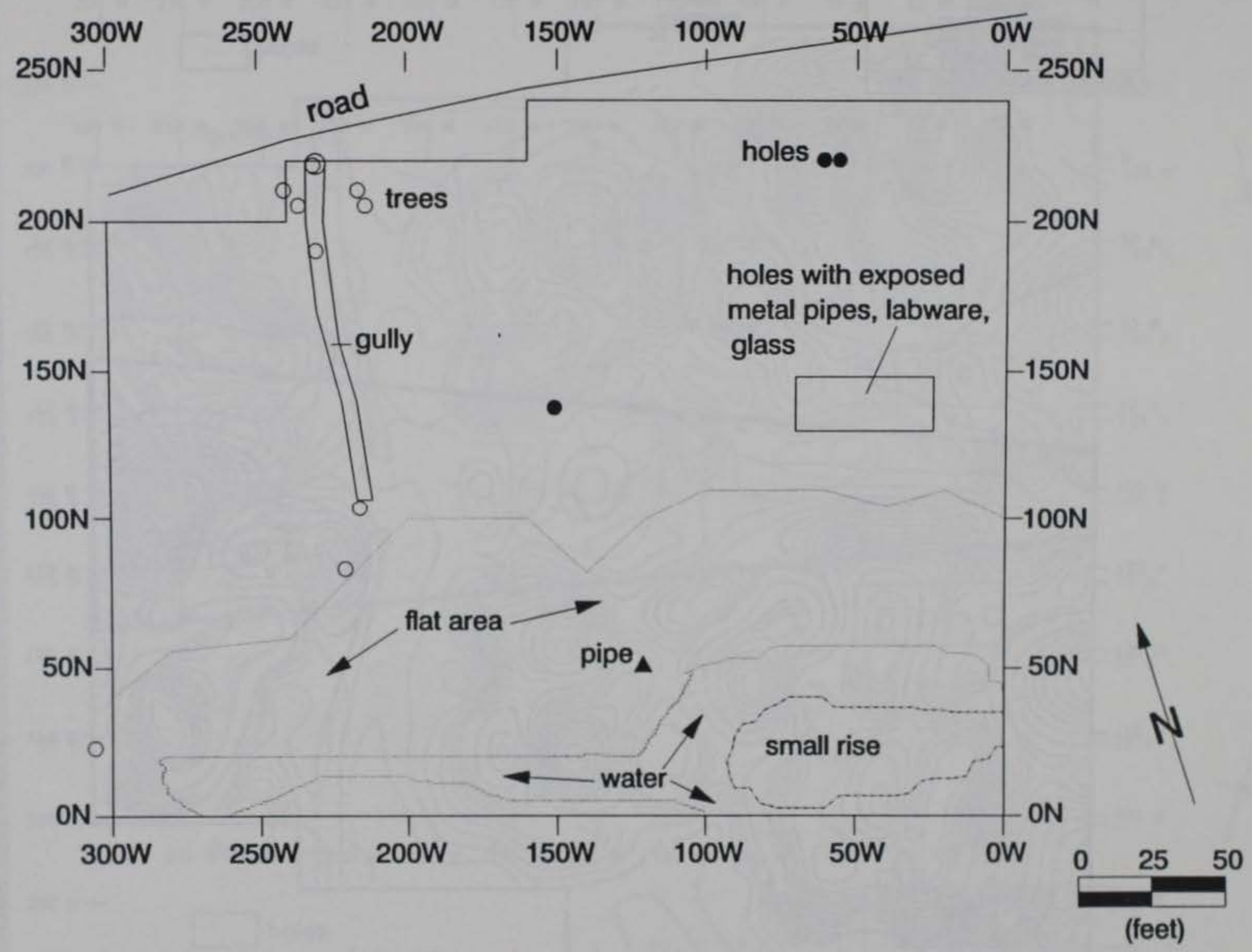

Figure 39. Site 3-3 site map 


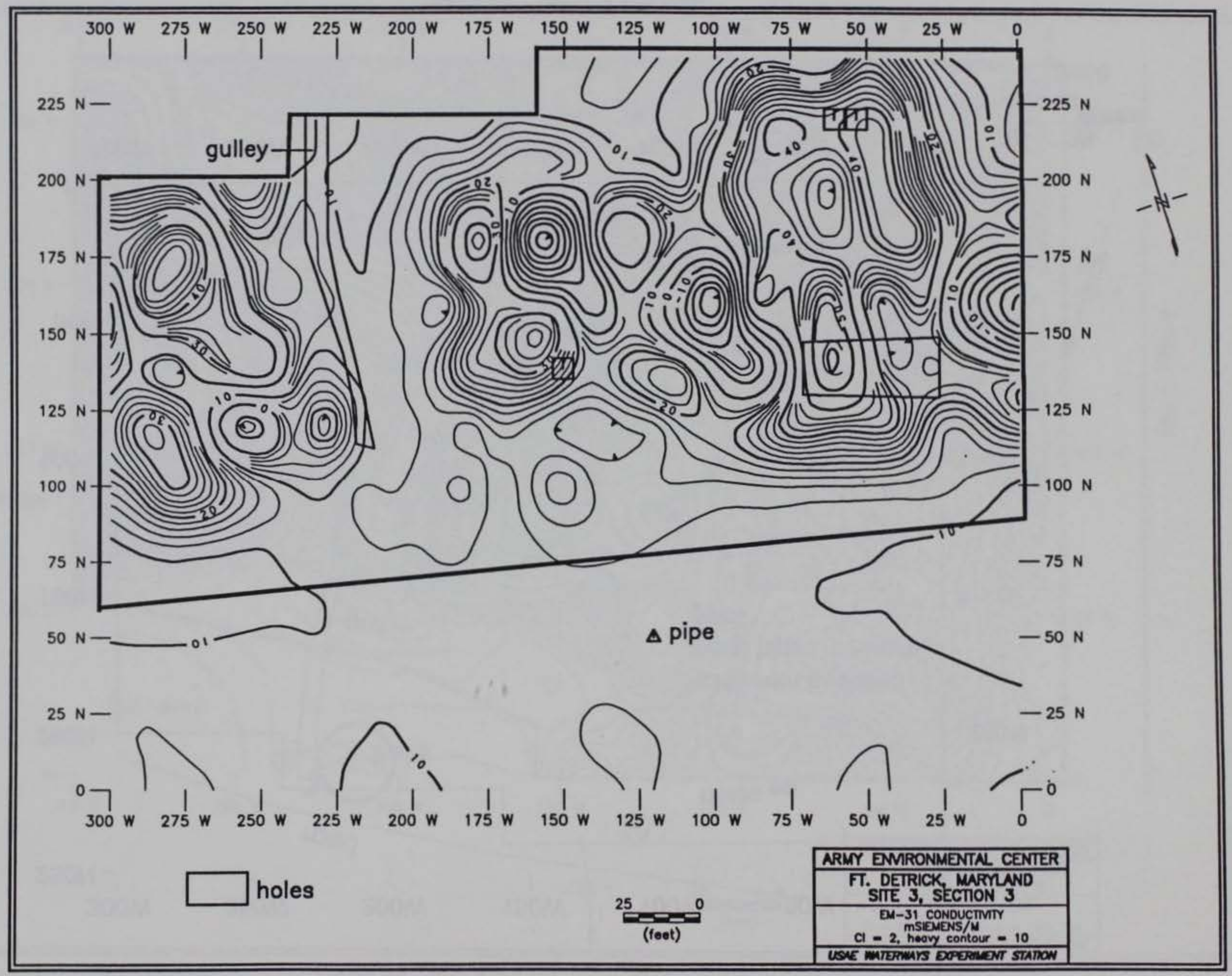

Figure 40 . Site $3-3$ conductivity results 


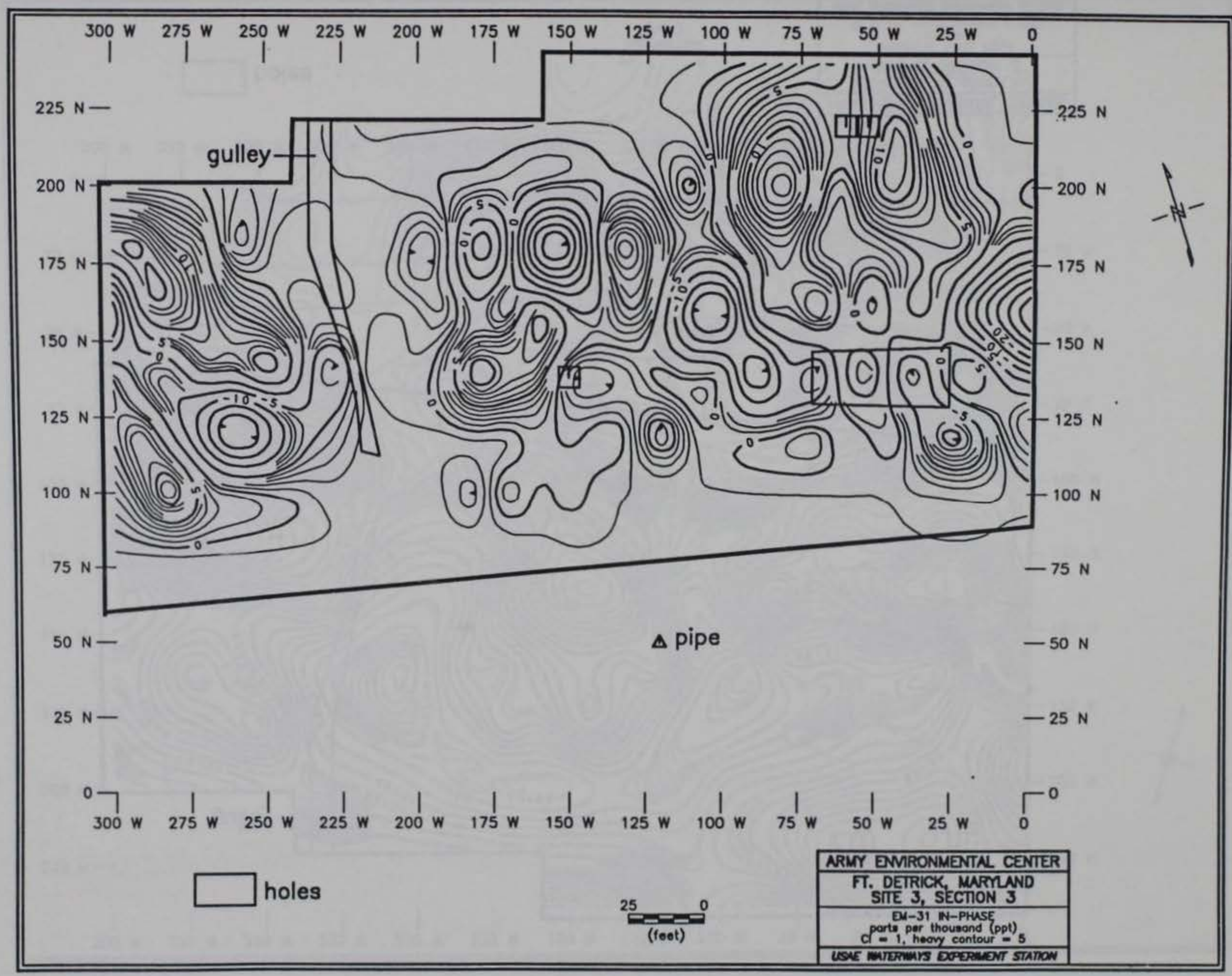

Figure 41. Site 3-3 in-phase results 


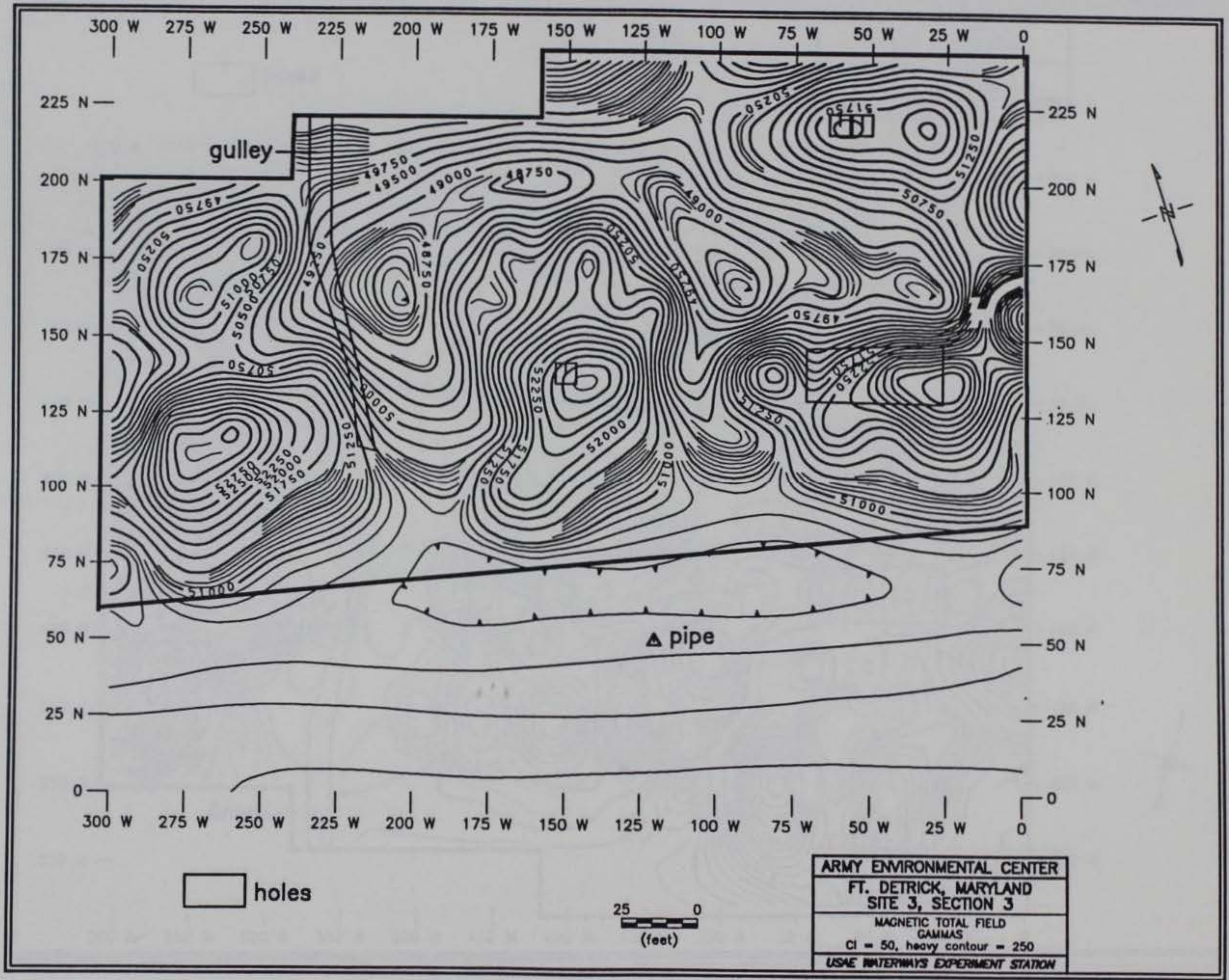

Figure 42. Site 3-3 total magnetic field survey results 


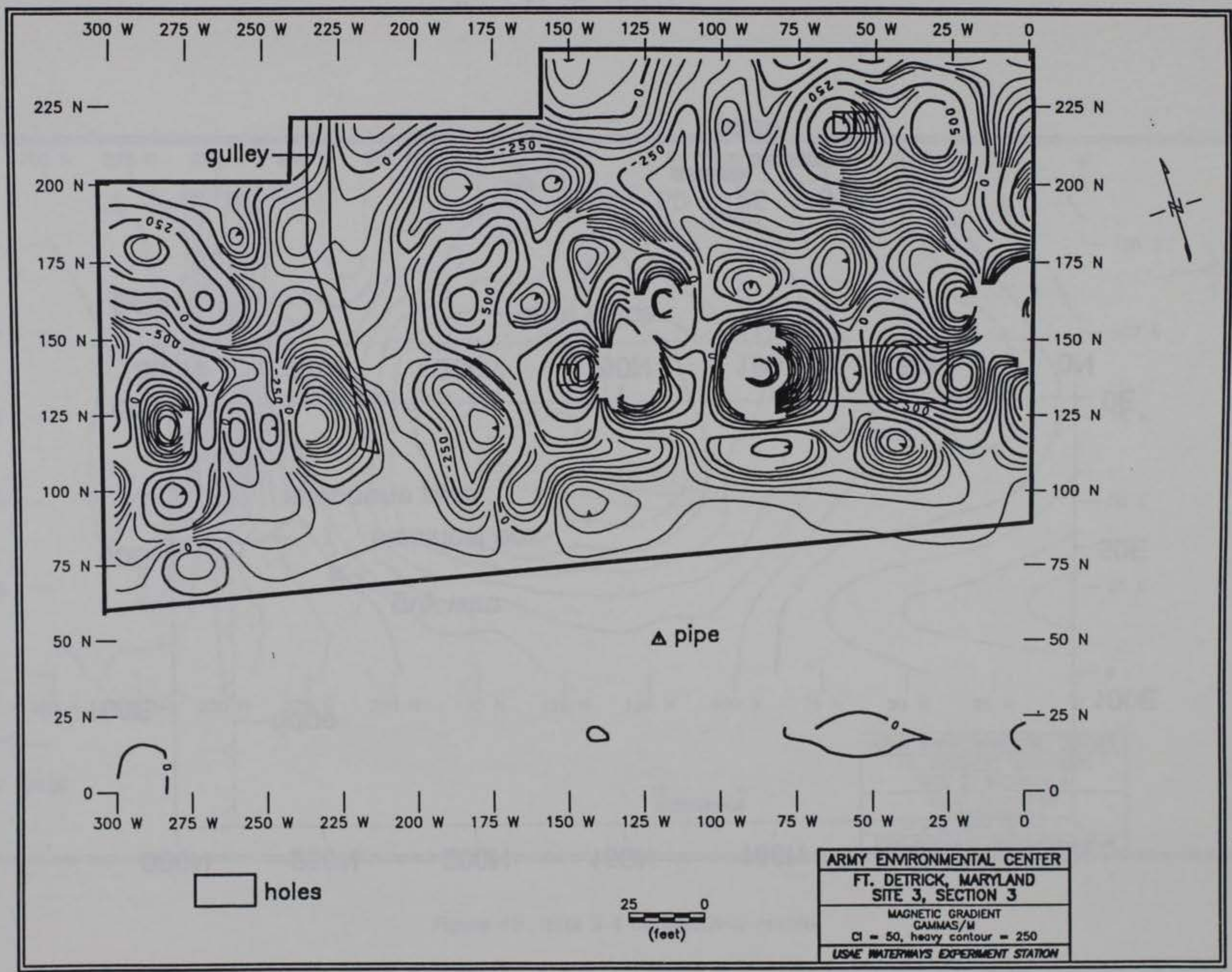

Figure 43. Site 3-3 magnetic gradient survey results 

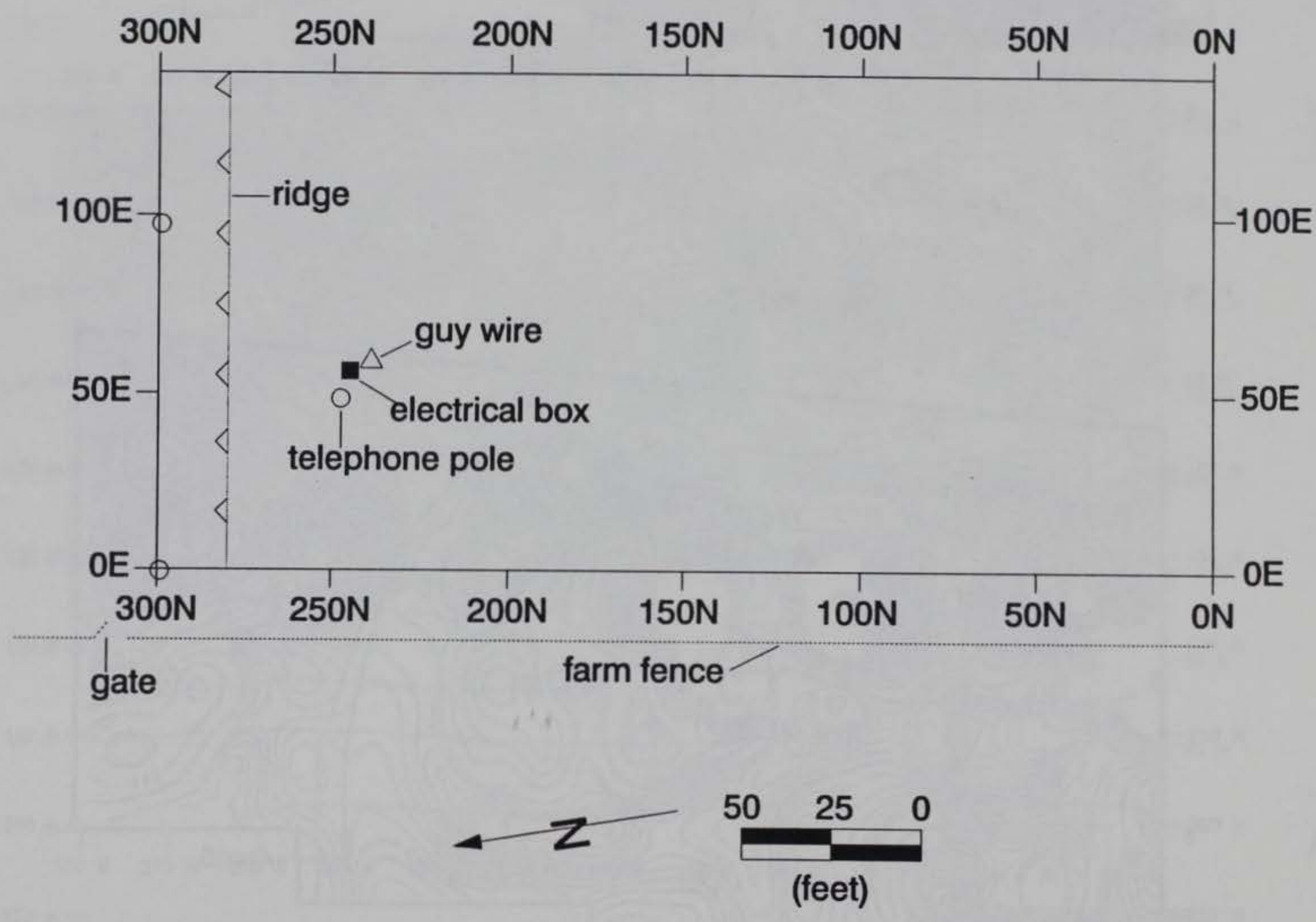

Figure 44. Site 3-4 site map 


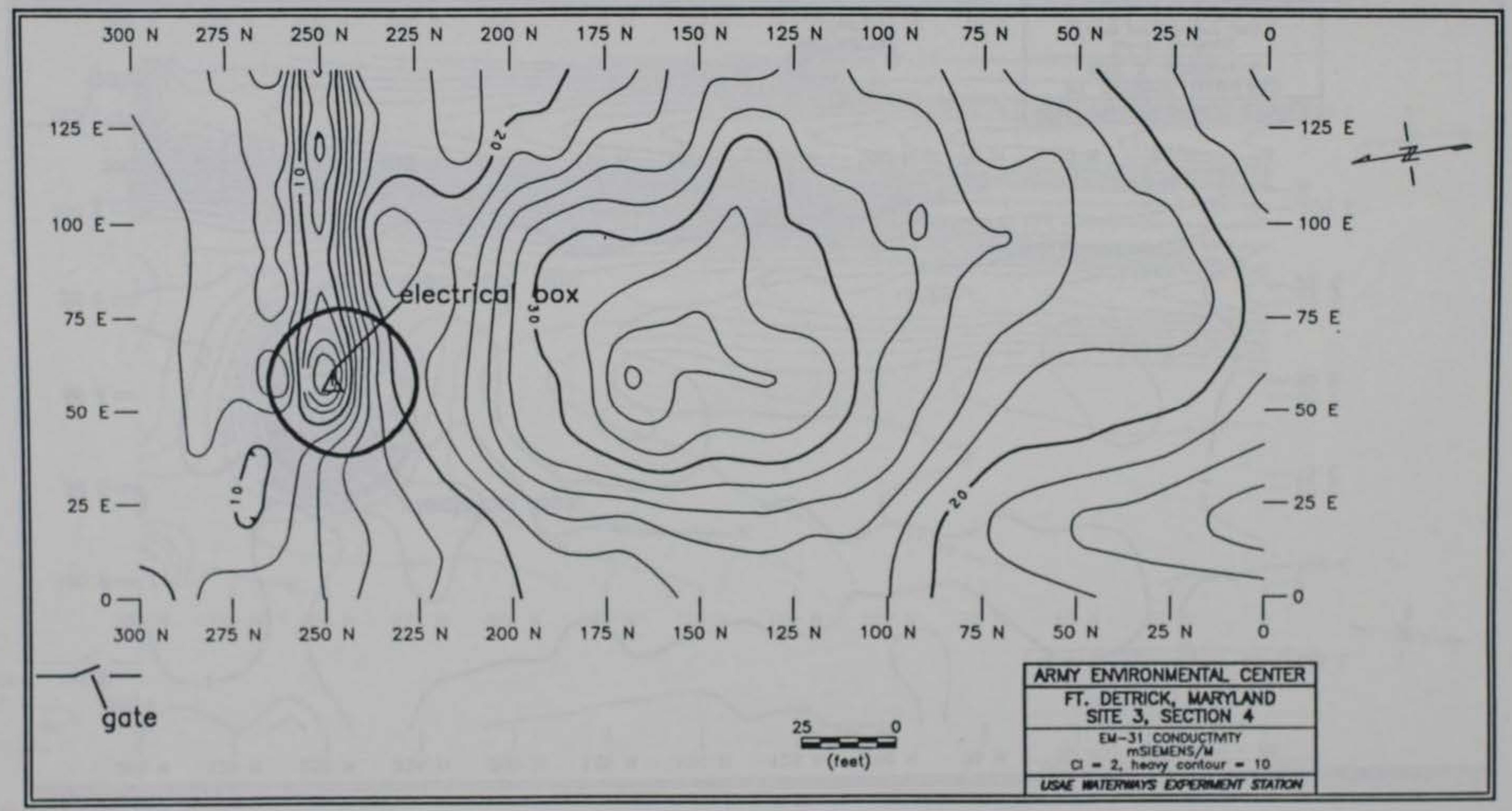

Figure 45 . Site $3-4$ conductivity results 


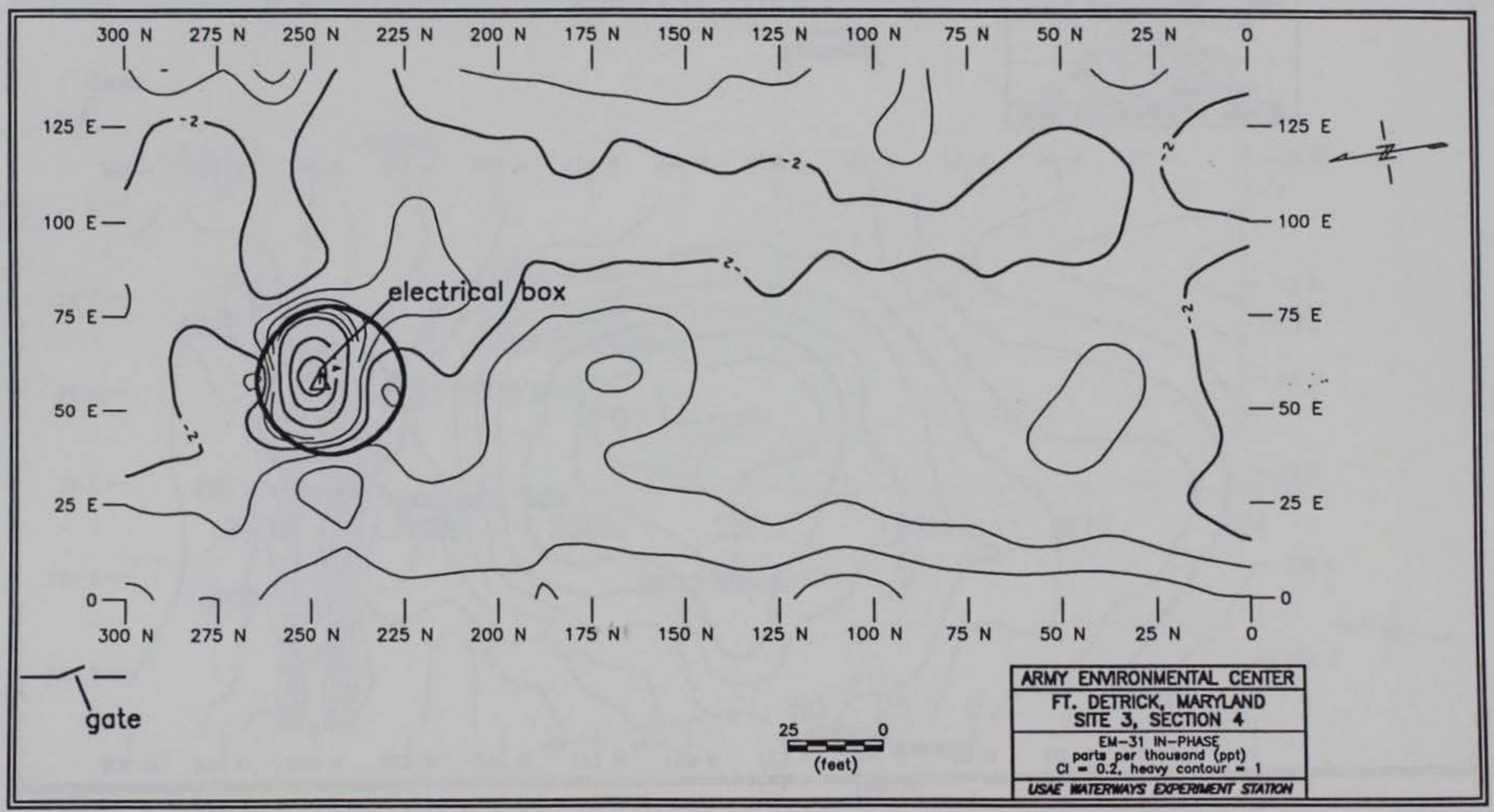

Figure 46. Site 3-4 in-phase results 


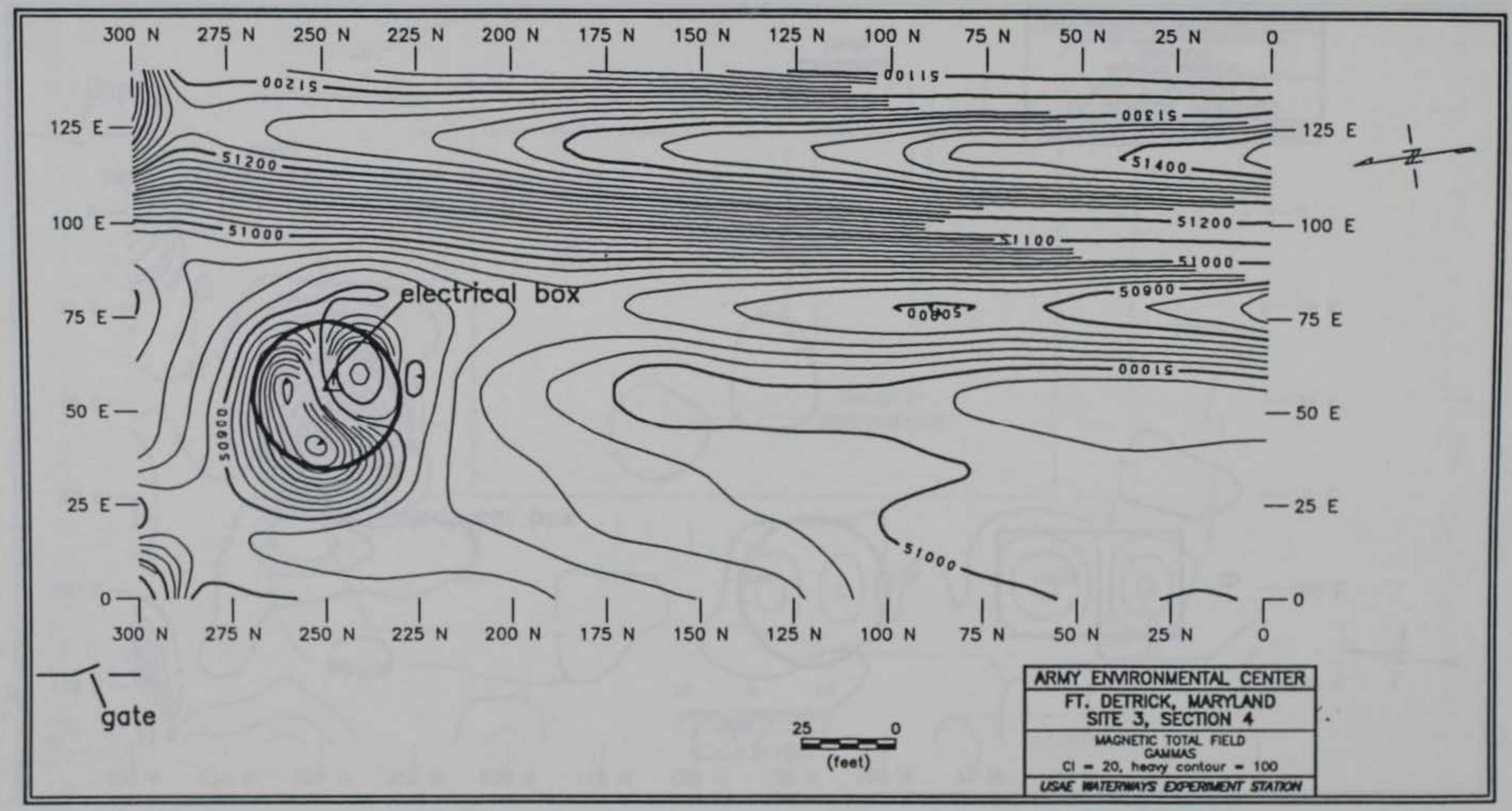

Figure 47. Site 3-4 total magnetic field survey results 


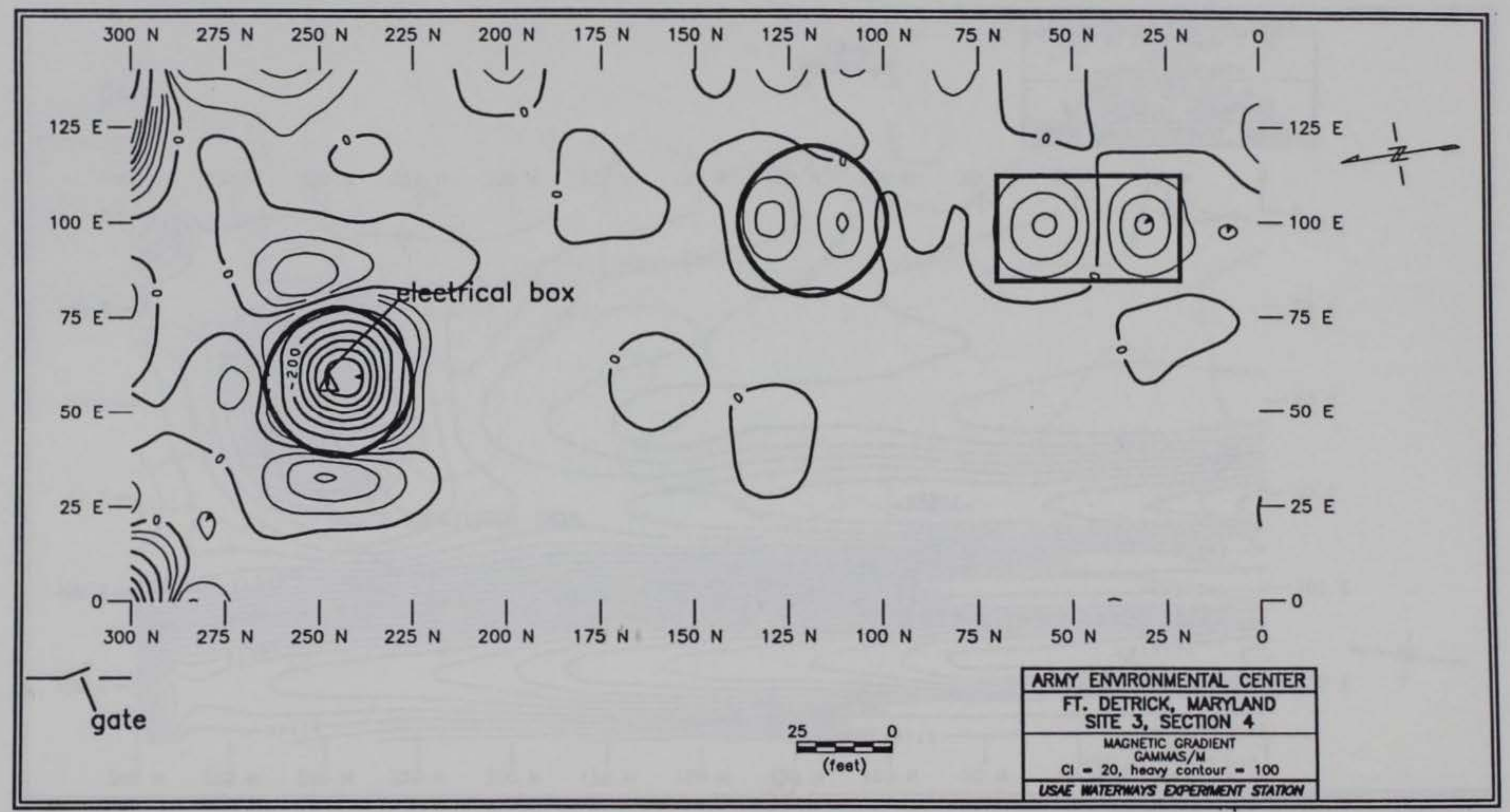

Figure 48. Site 3-4 magnetic gradient survey results 


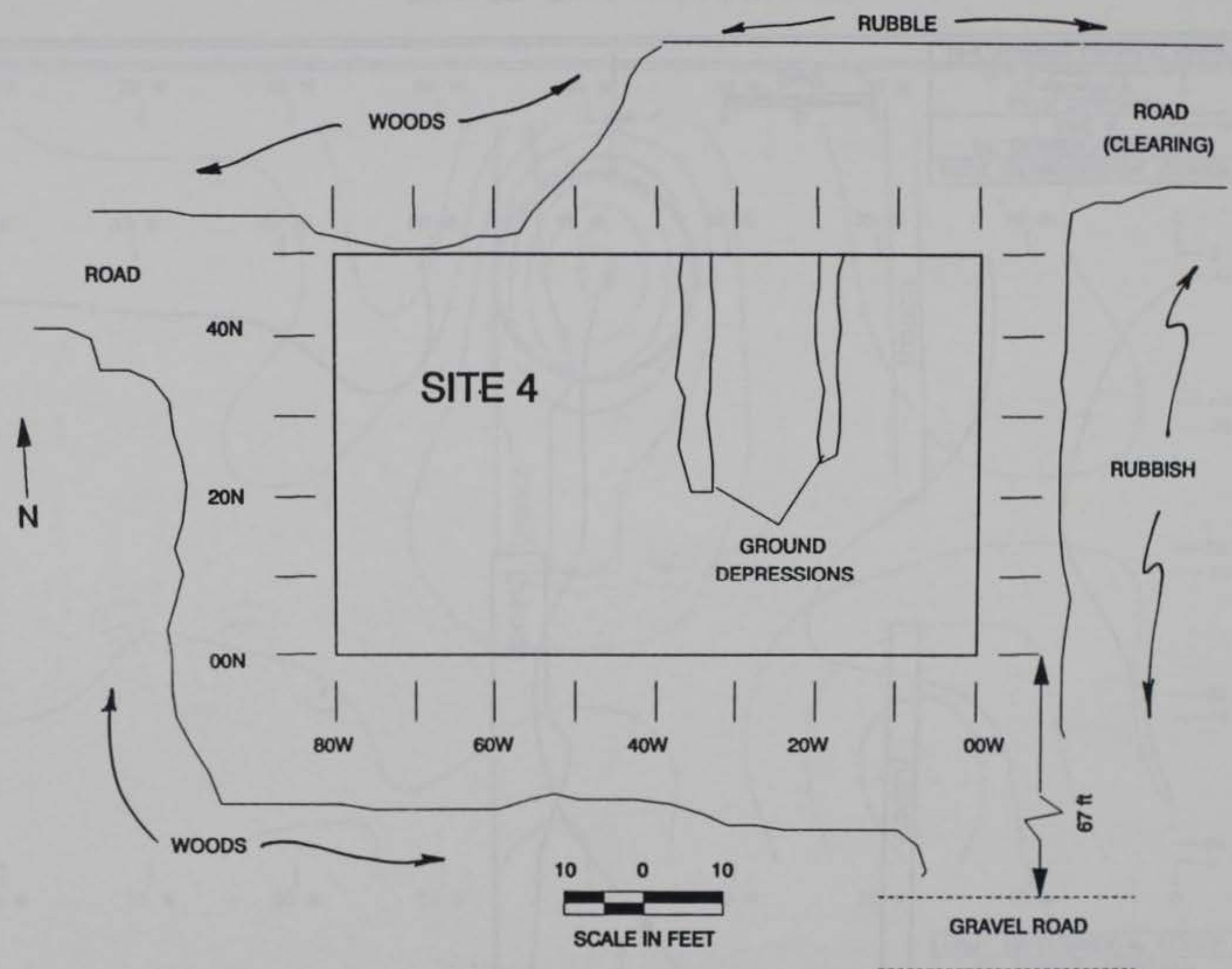

Figure 49. Site 4 site map 


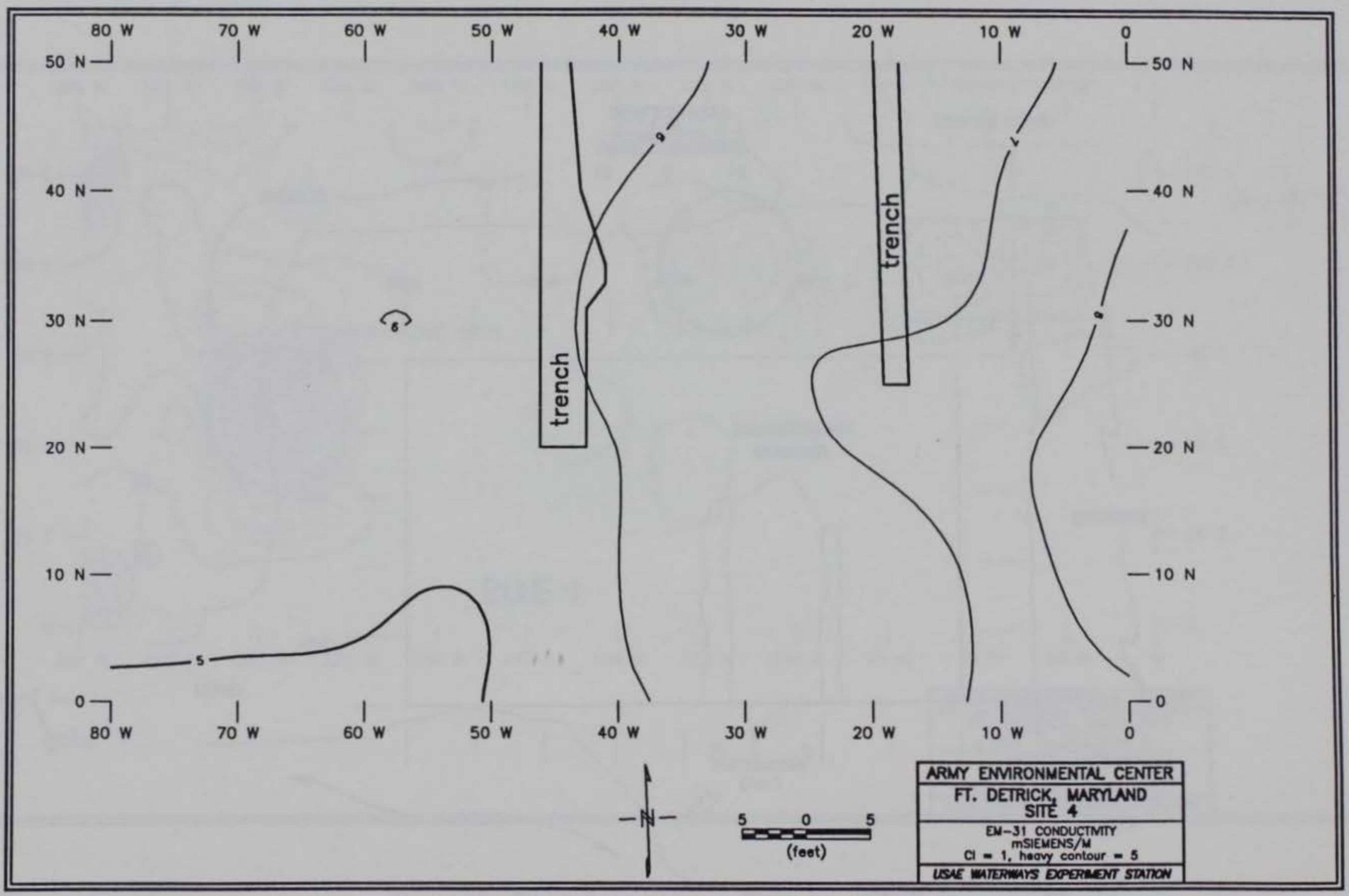

Figure 50. Site 4 conductivity results 


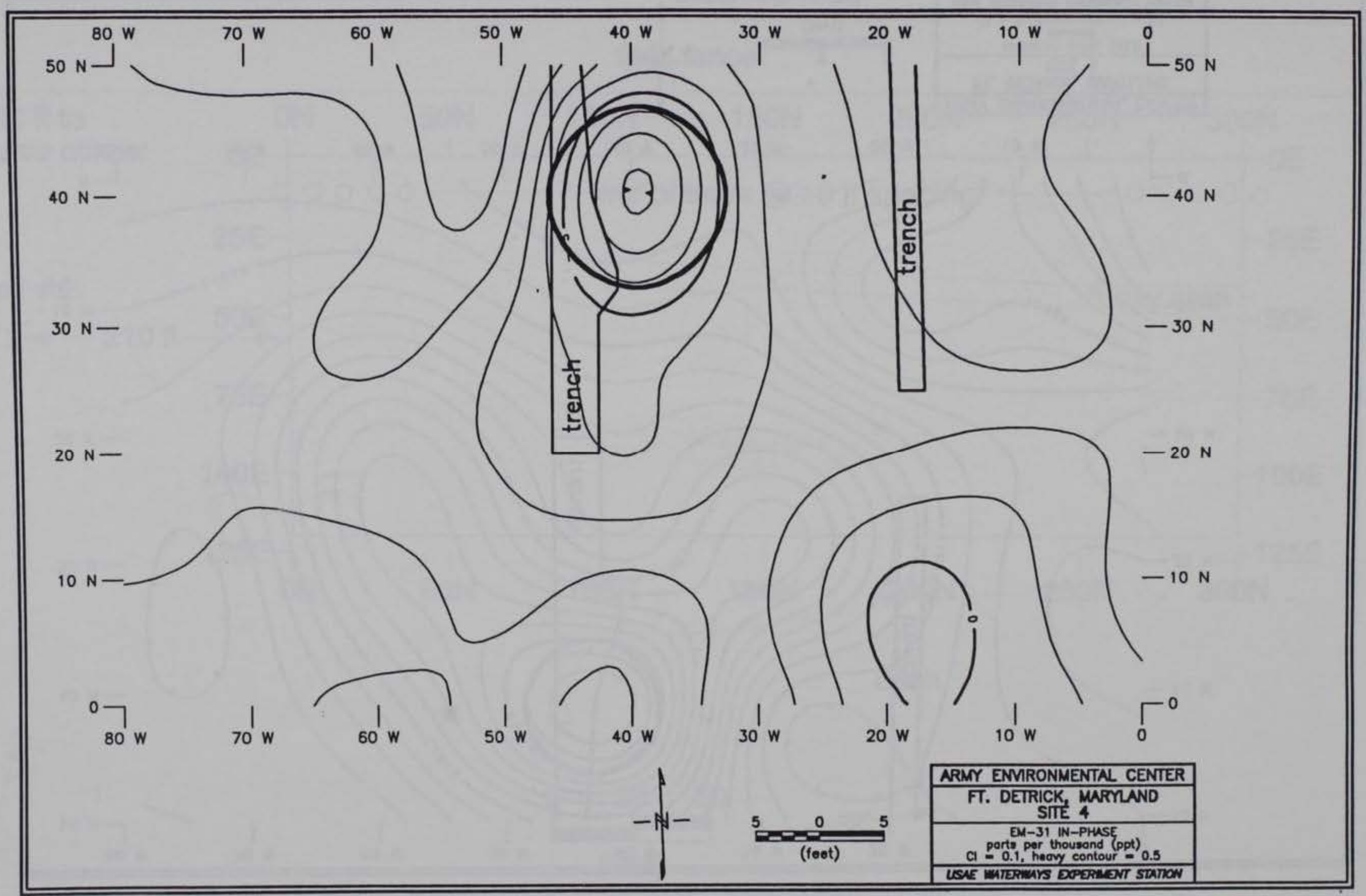

Figure 51. Site 4 in-phase results 


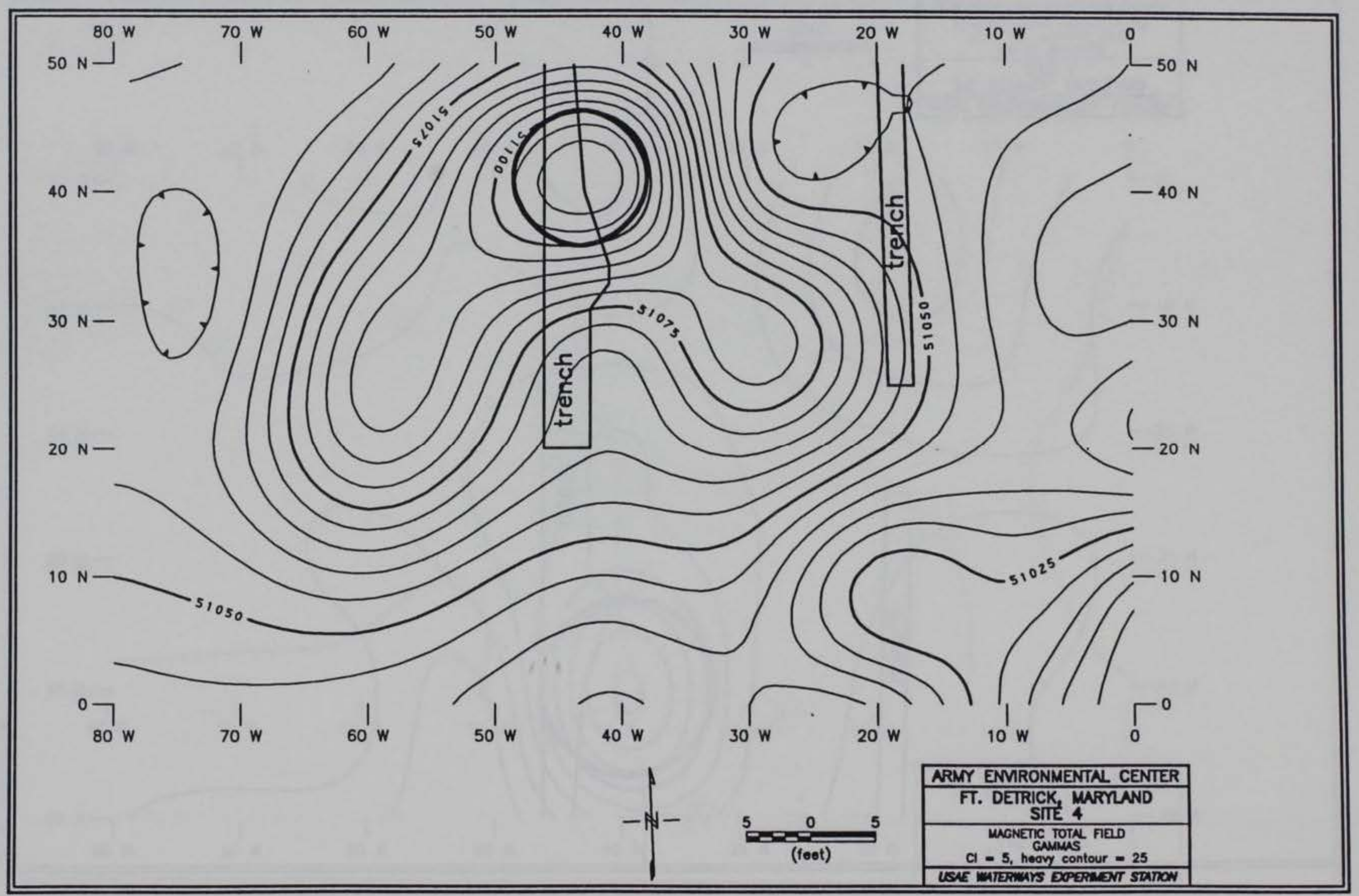

Figure 52. Site 4 total magnetic field survey results 
blacktop road

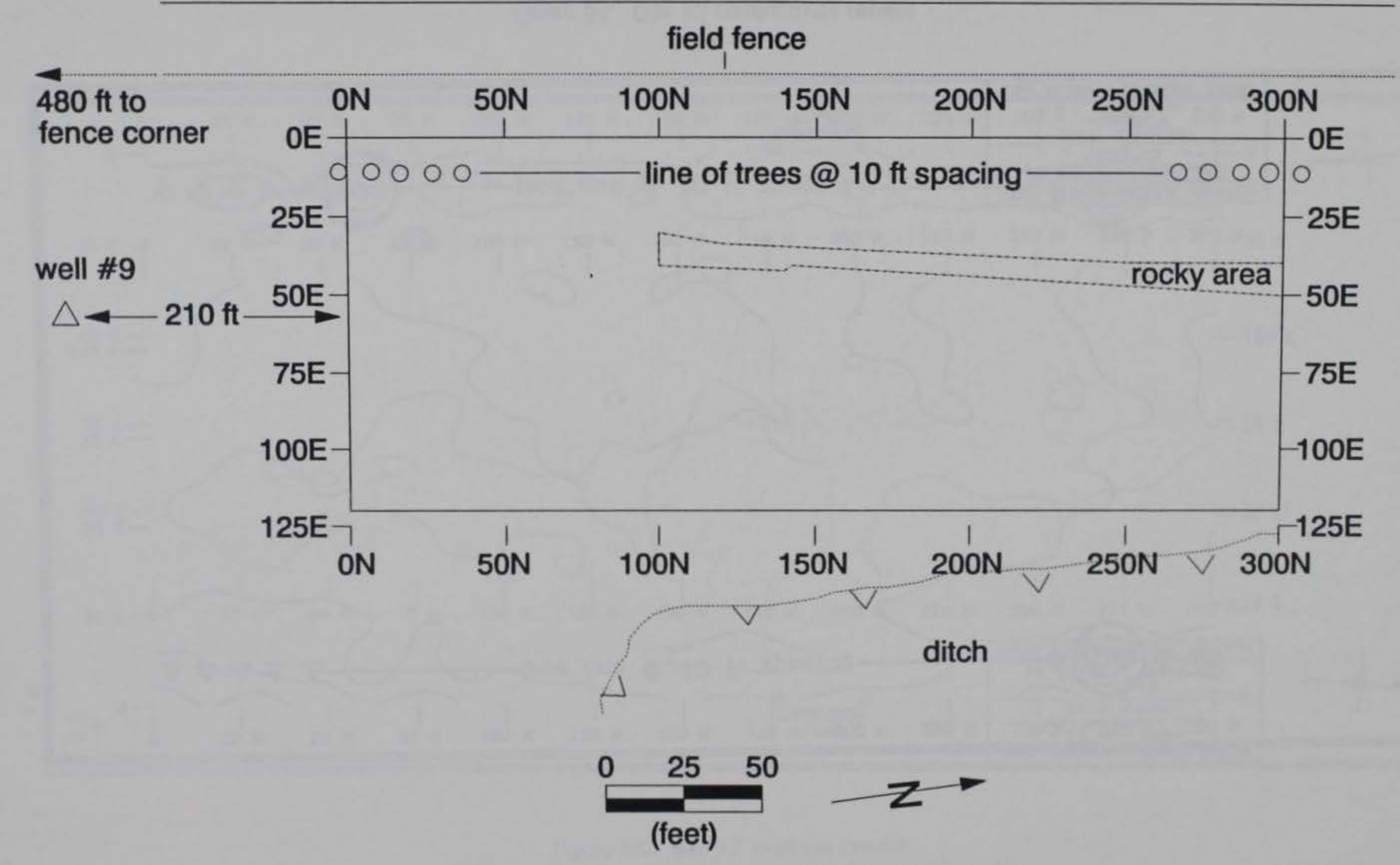

Figure 53. Site 13 site map 


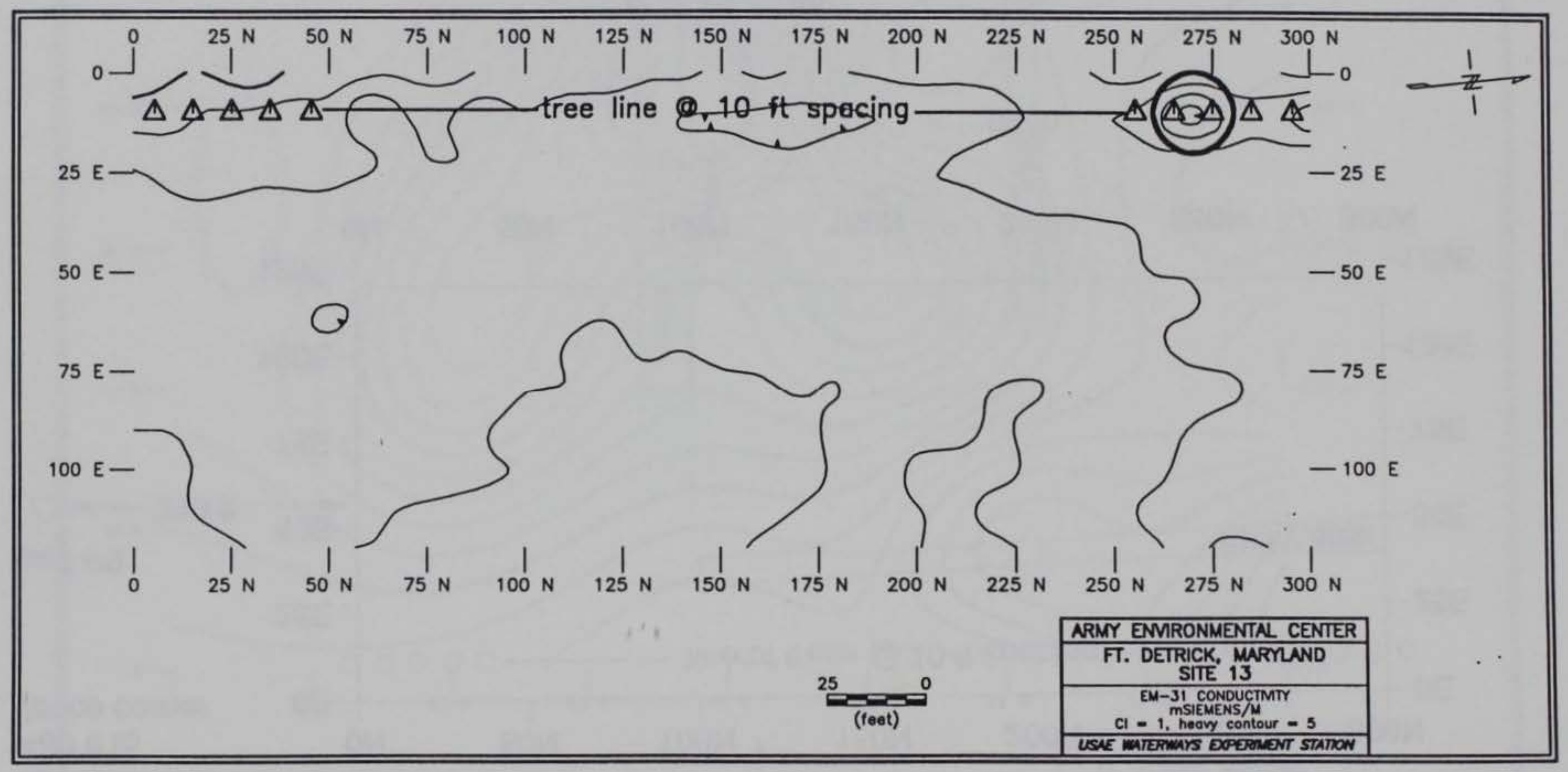

Figure 54 . Site 13 conductivity results 


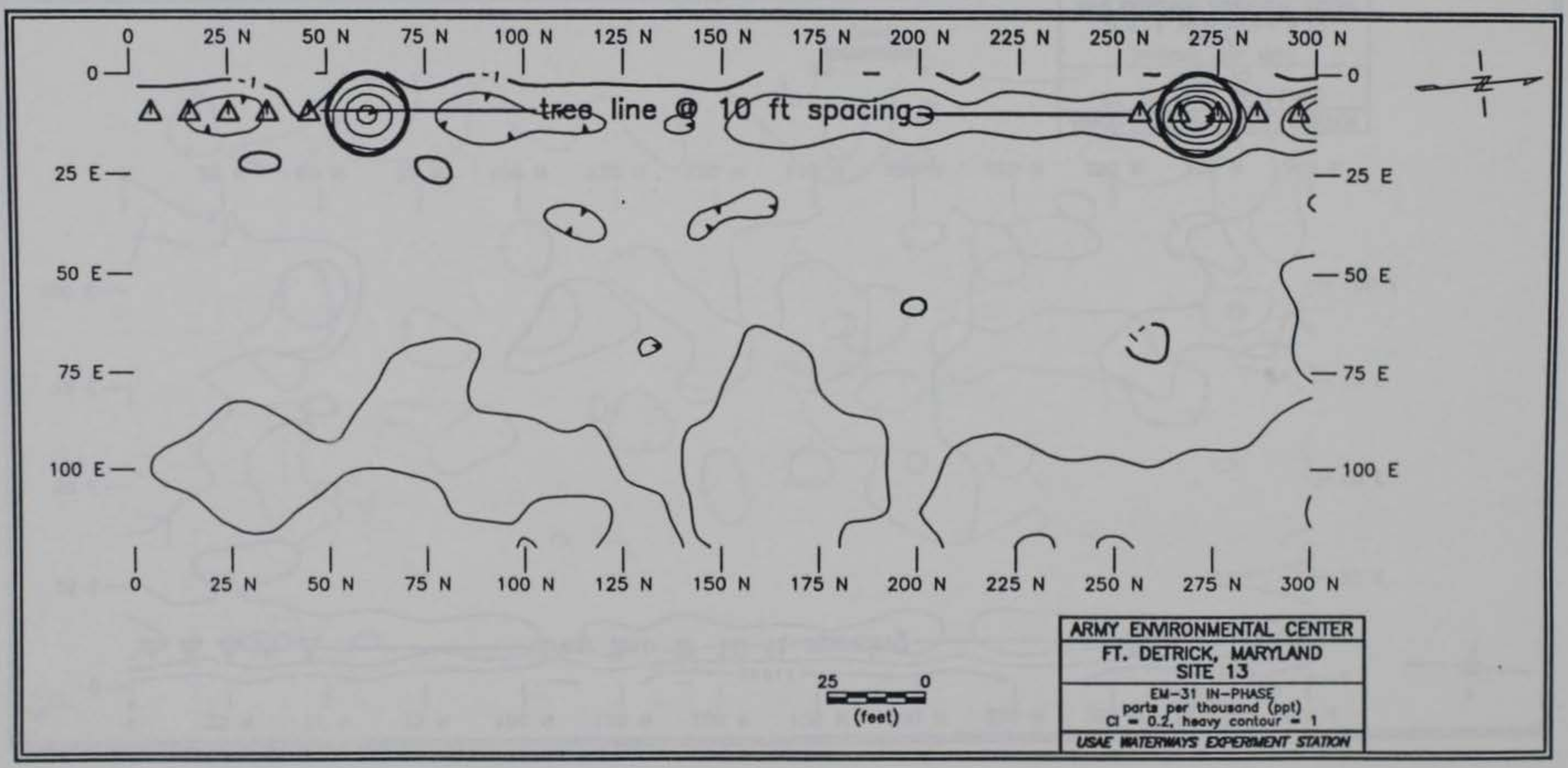

Figure 55. Site 13 in-phase results 


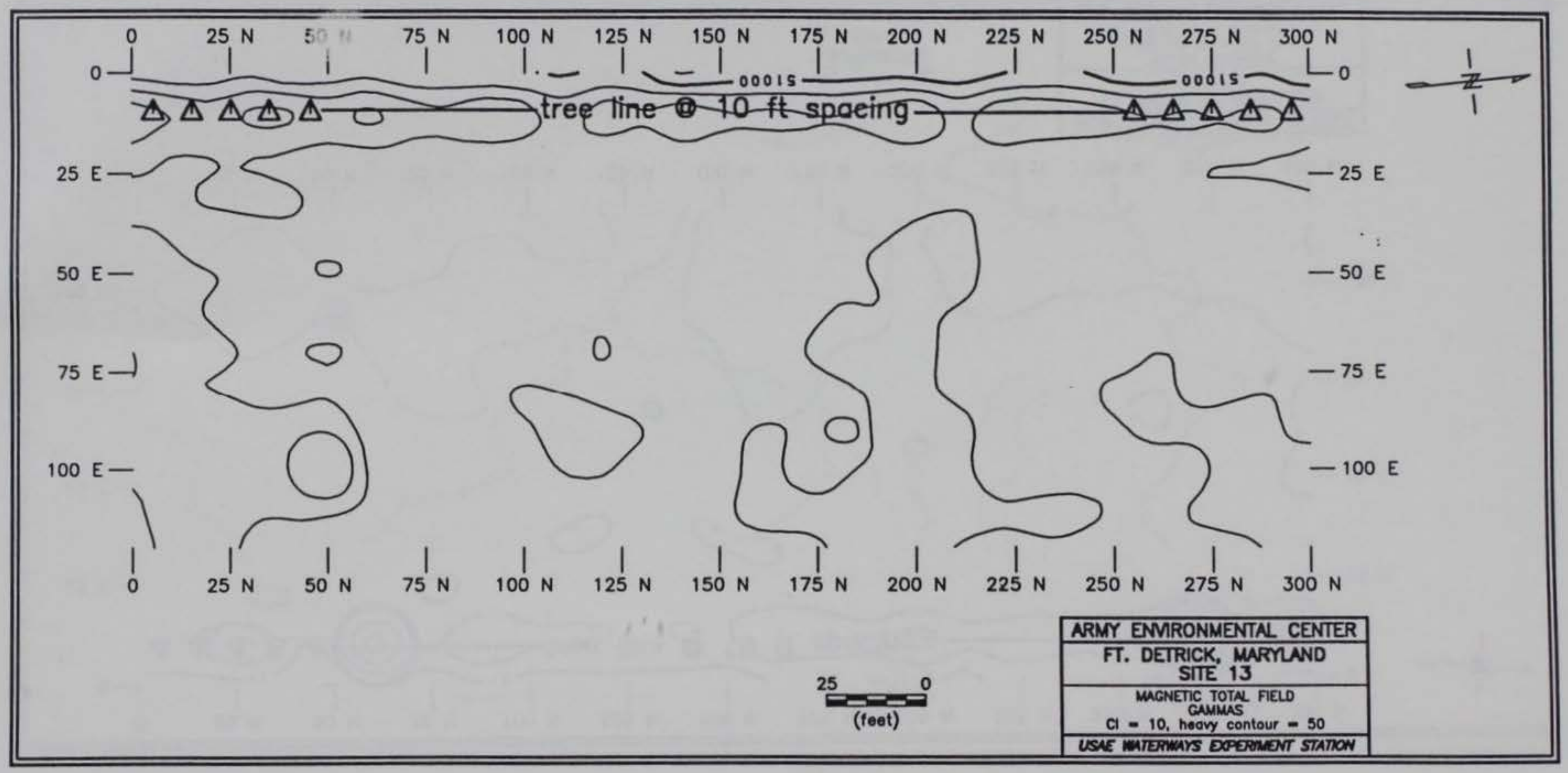

Figure 56. Site 13 total magnetic field survey results 


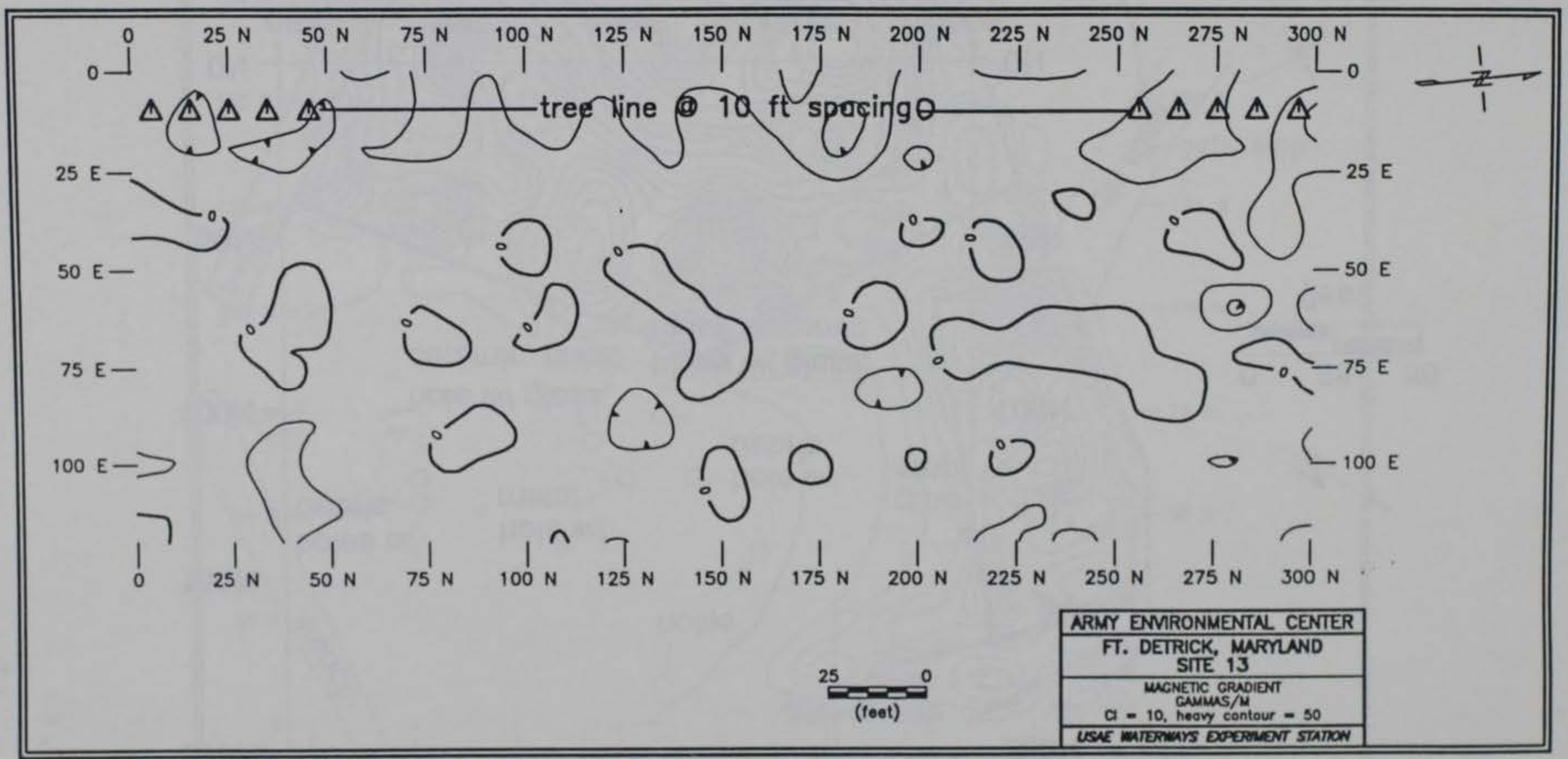

Figure 57 . Site 13 magnetic gradient survey results 


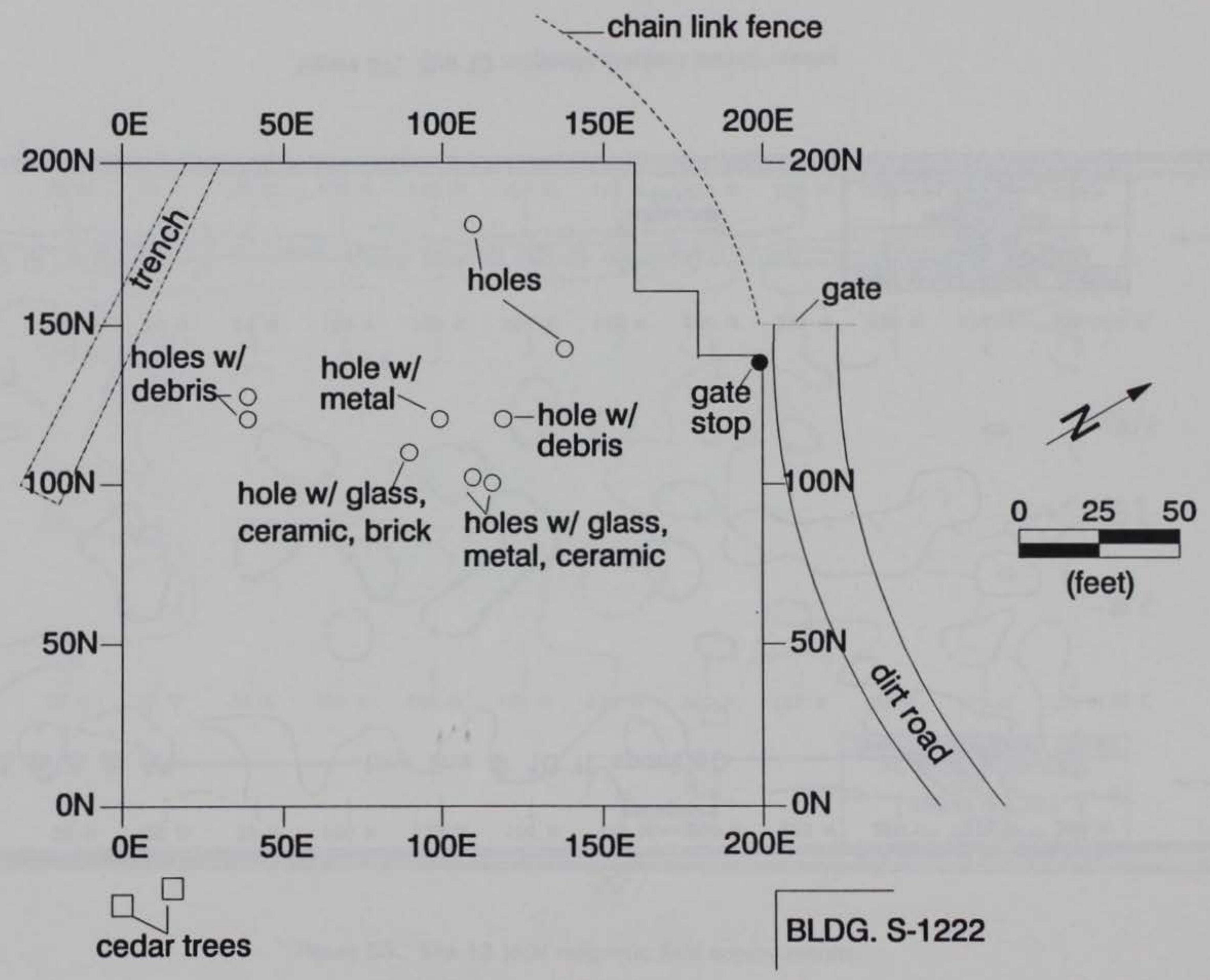

Figure 58. Gate Site map 


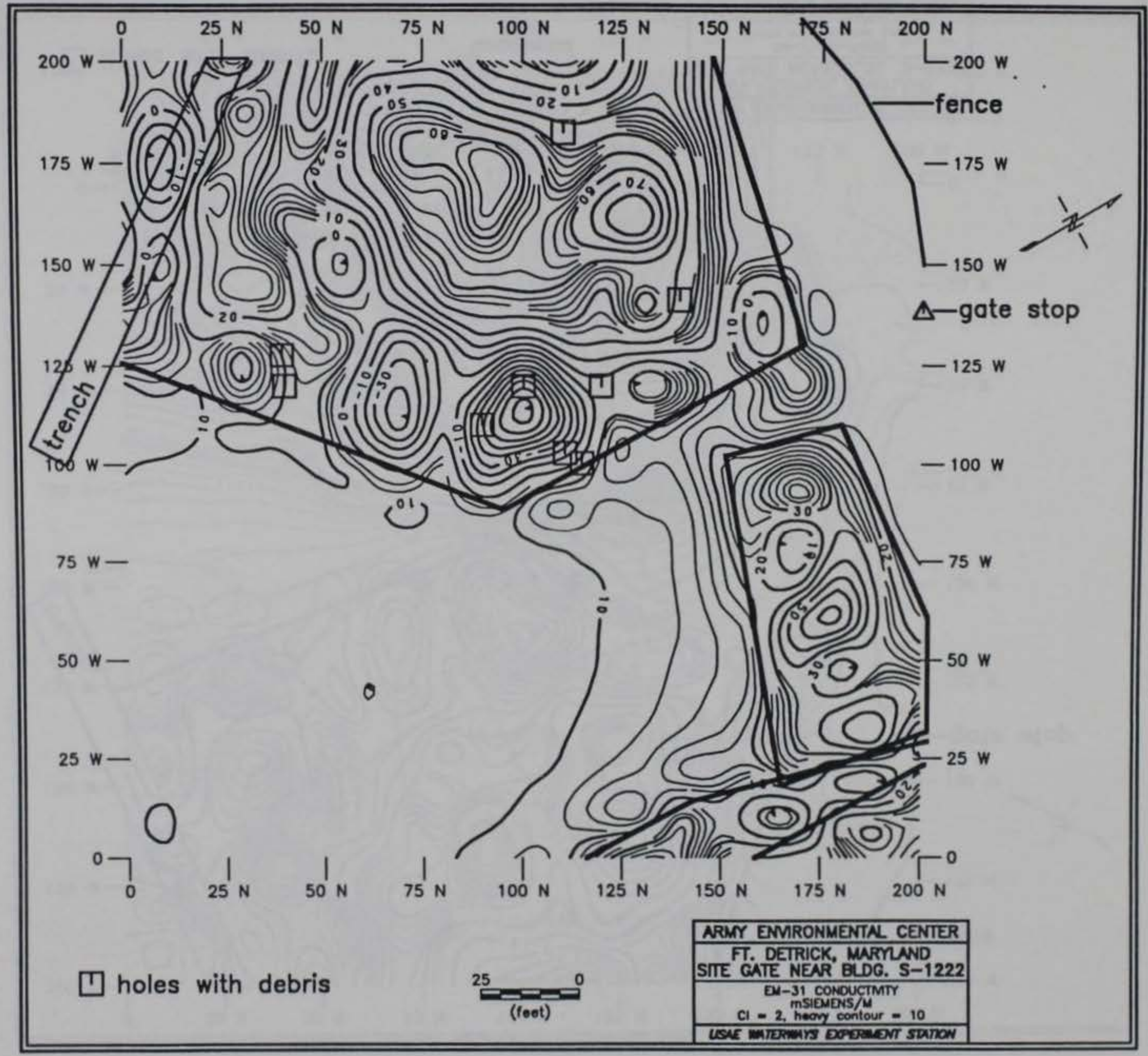

Figure 59. Gate Site conductivity results 


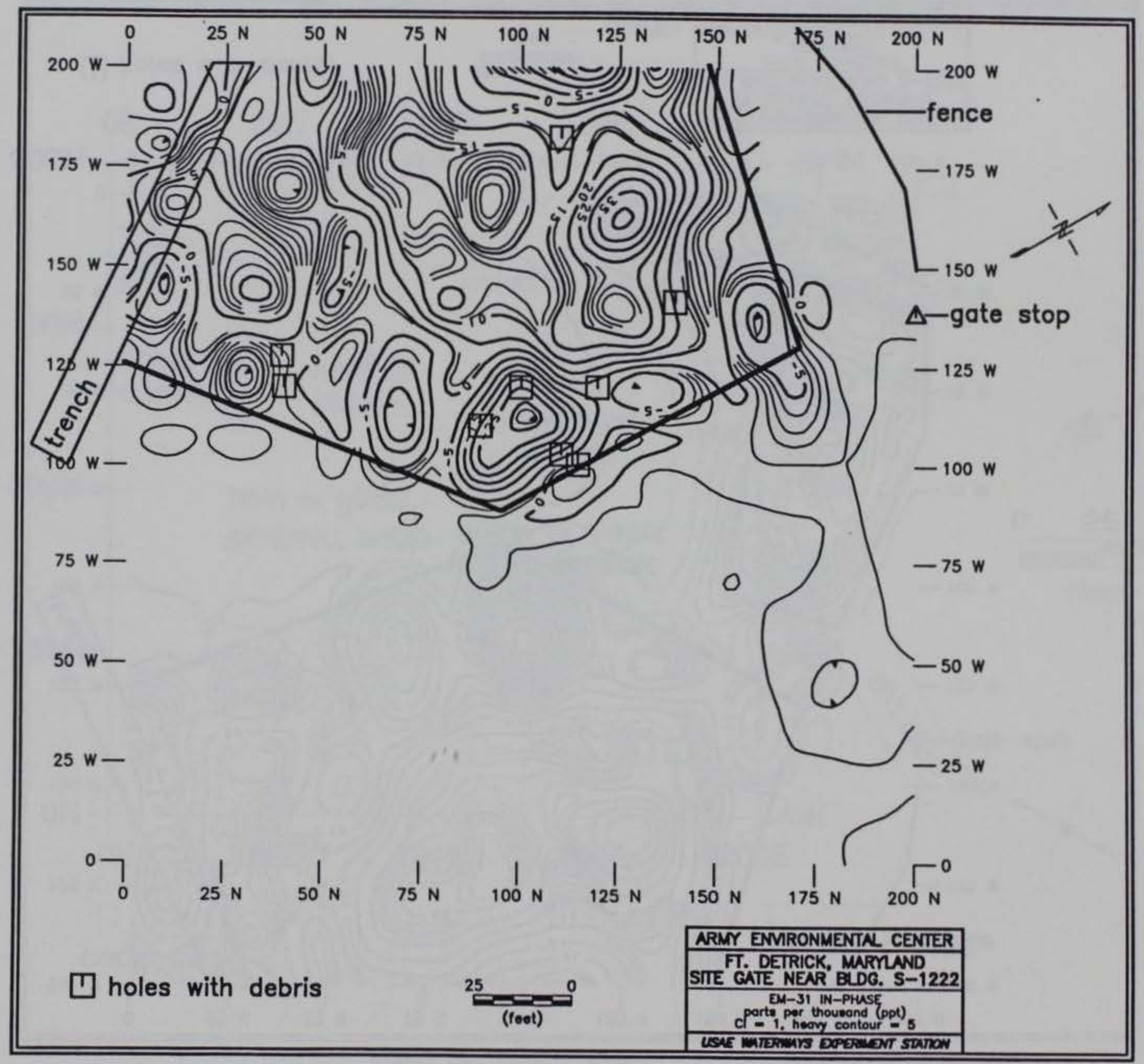

Figure 60. Gate Site in-phase results 


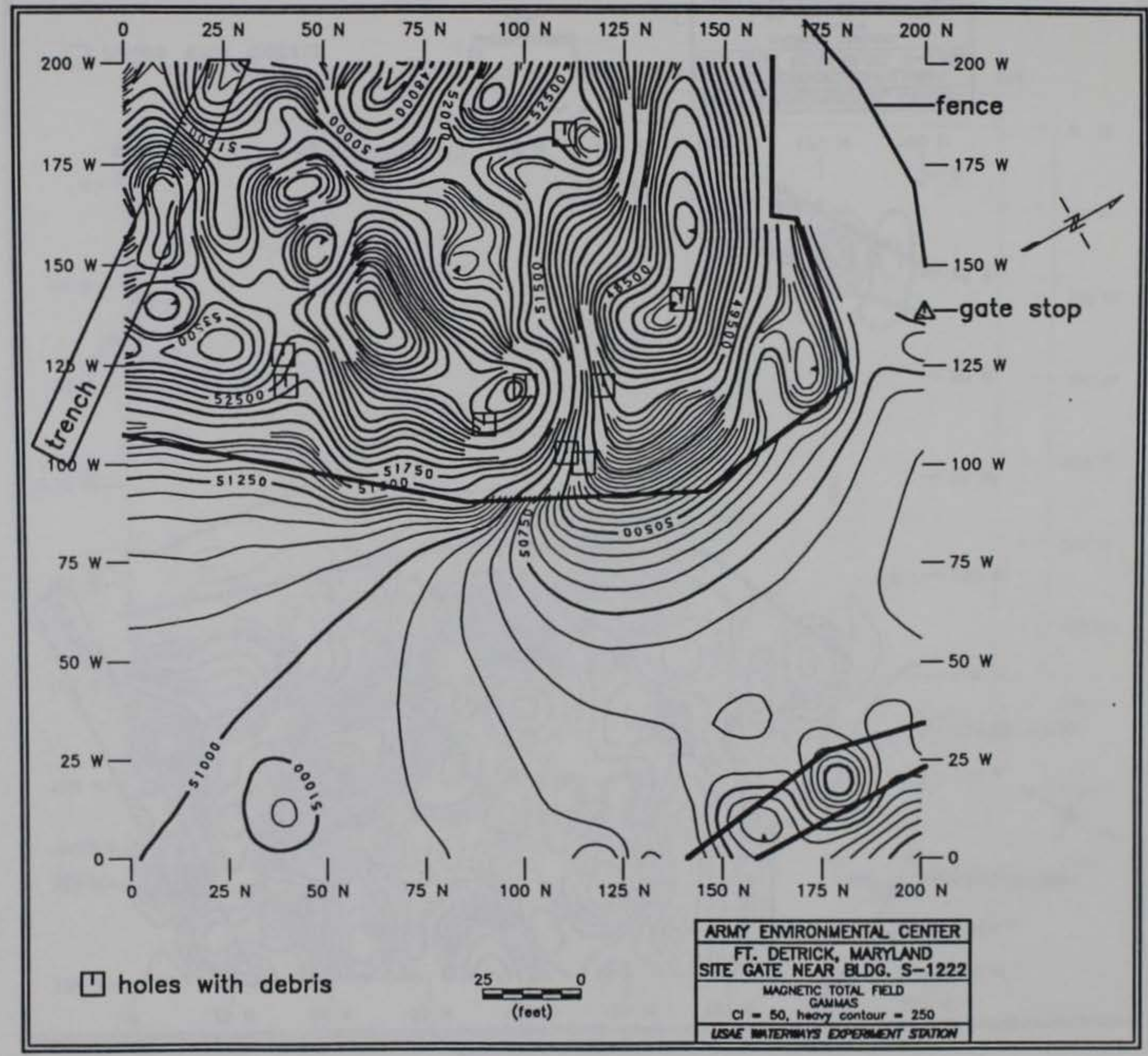

Figure 61. Gate Site total magnetic field survey results 


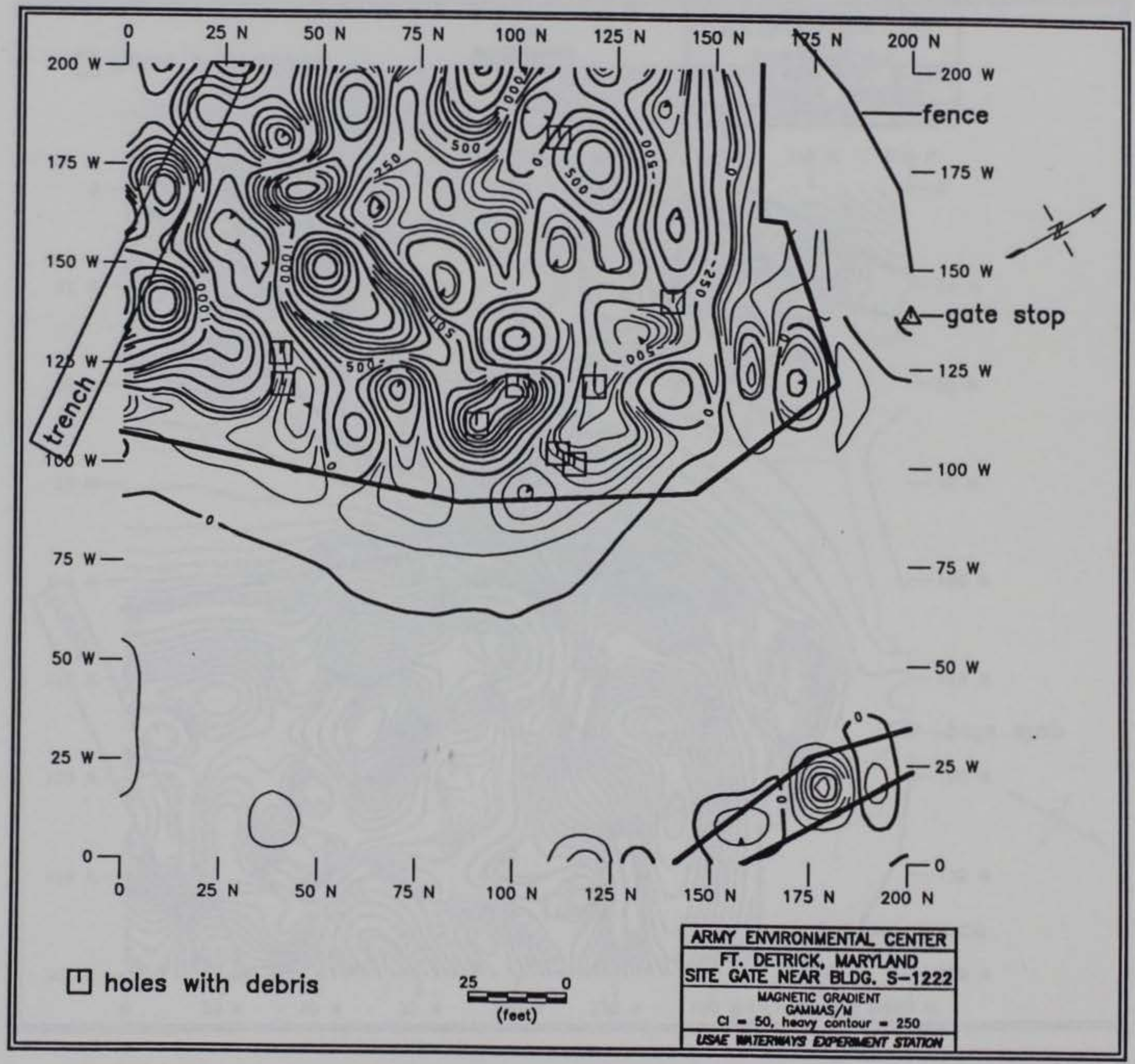

Figure 62. Gate Site magnetic gradient survey results 


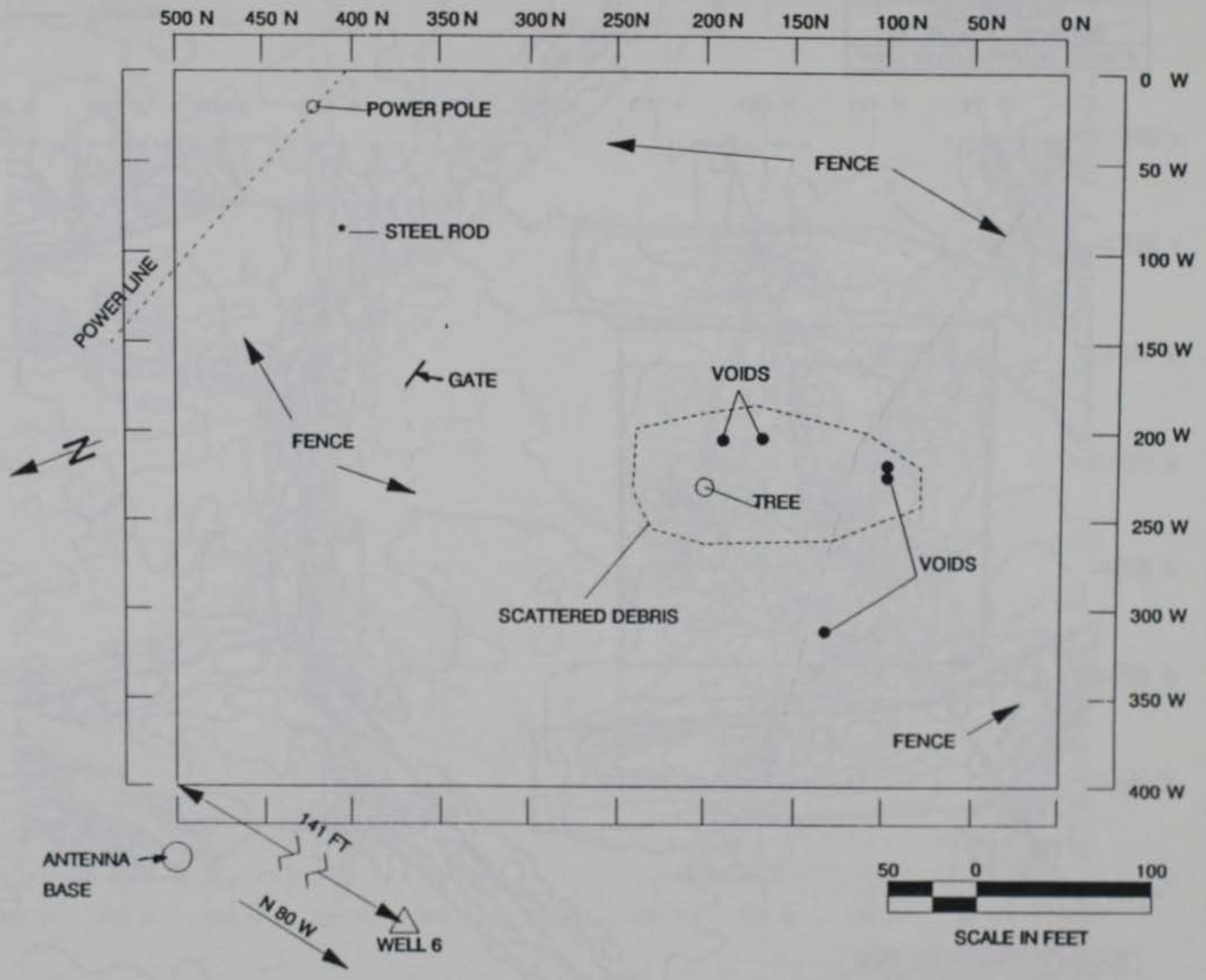

Figure 63. Antenna Site map 


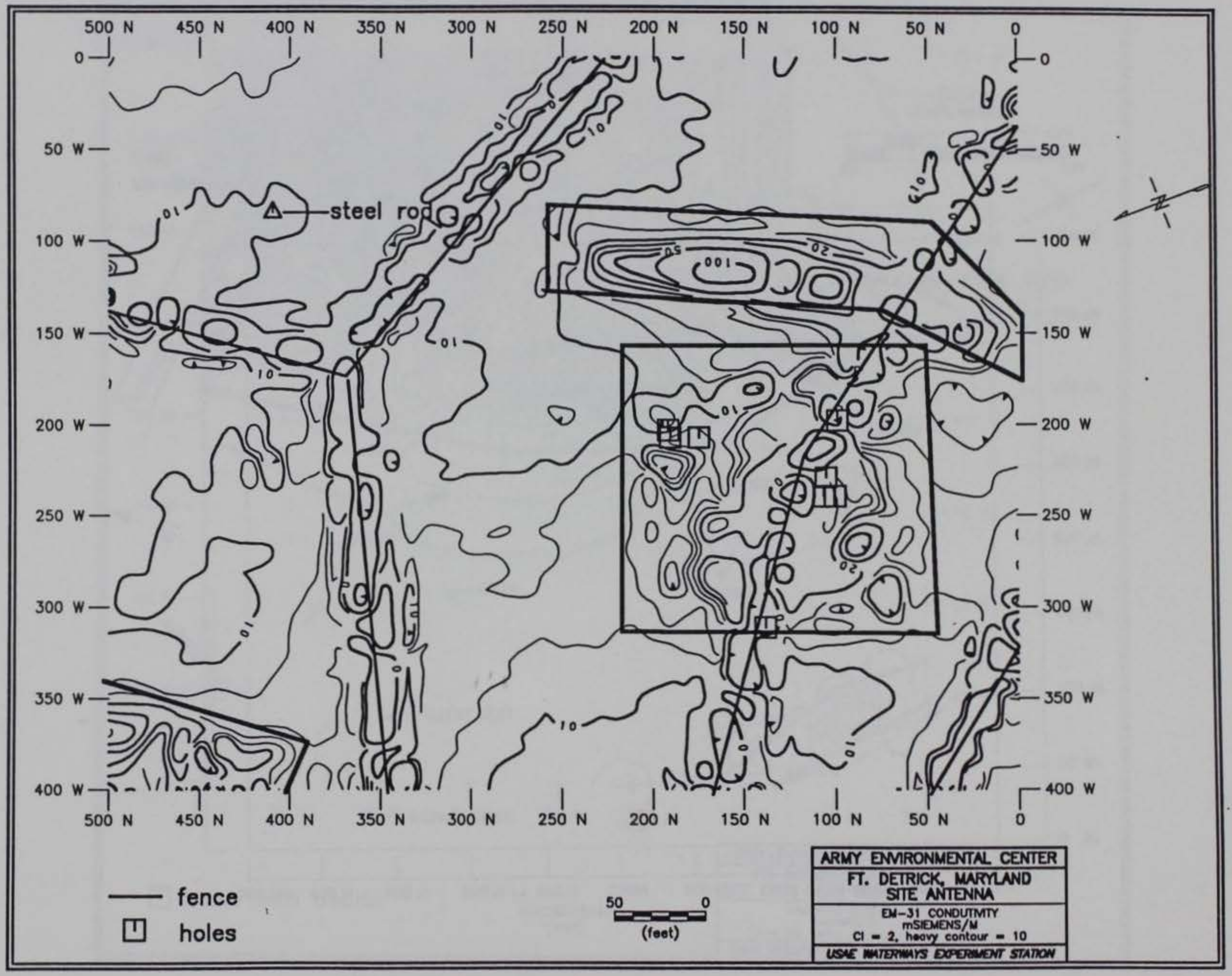

Figure 64. Antenna Site conductivity results 


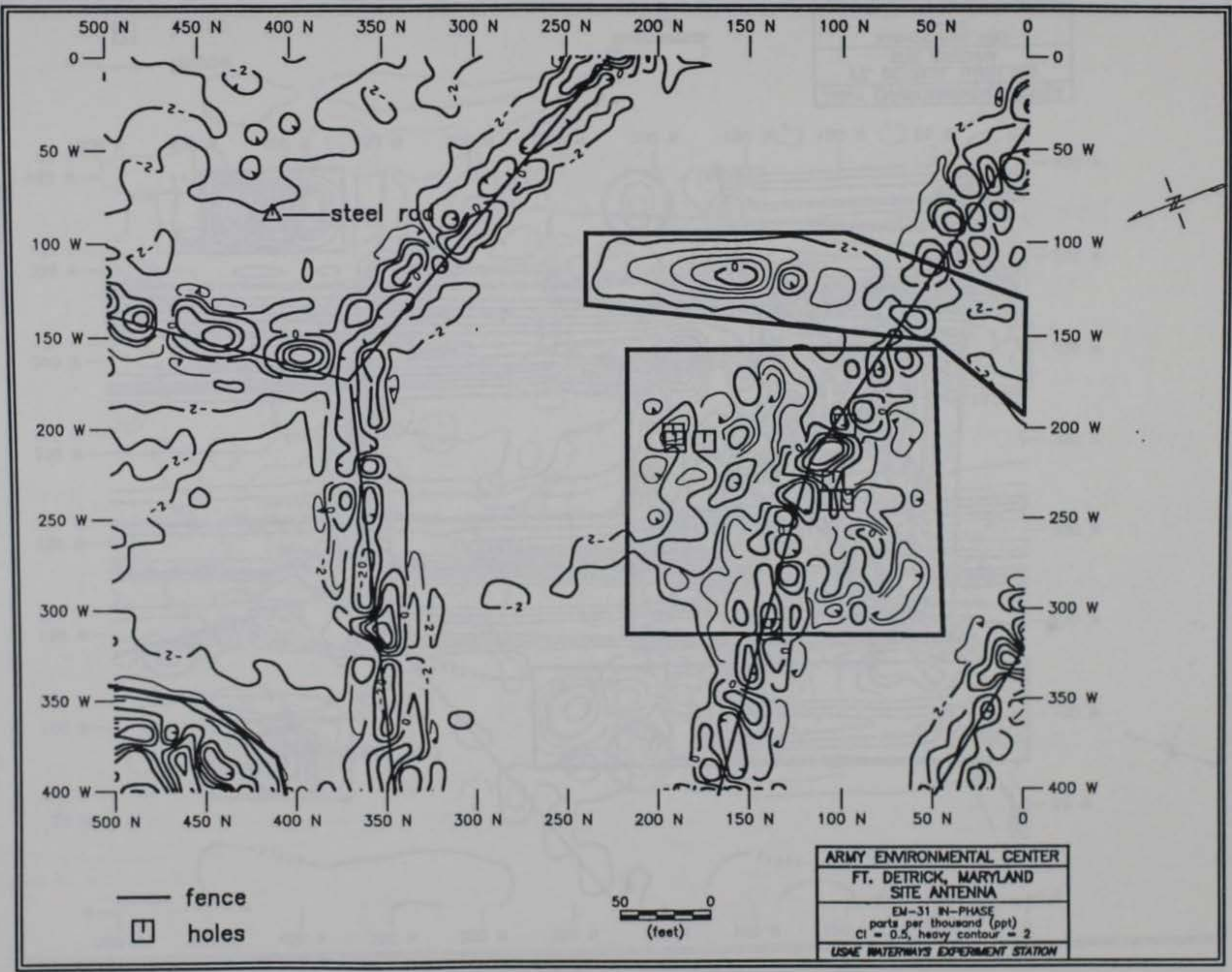

Figure 65. Antenna Site in-phase results 


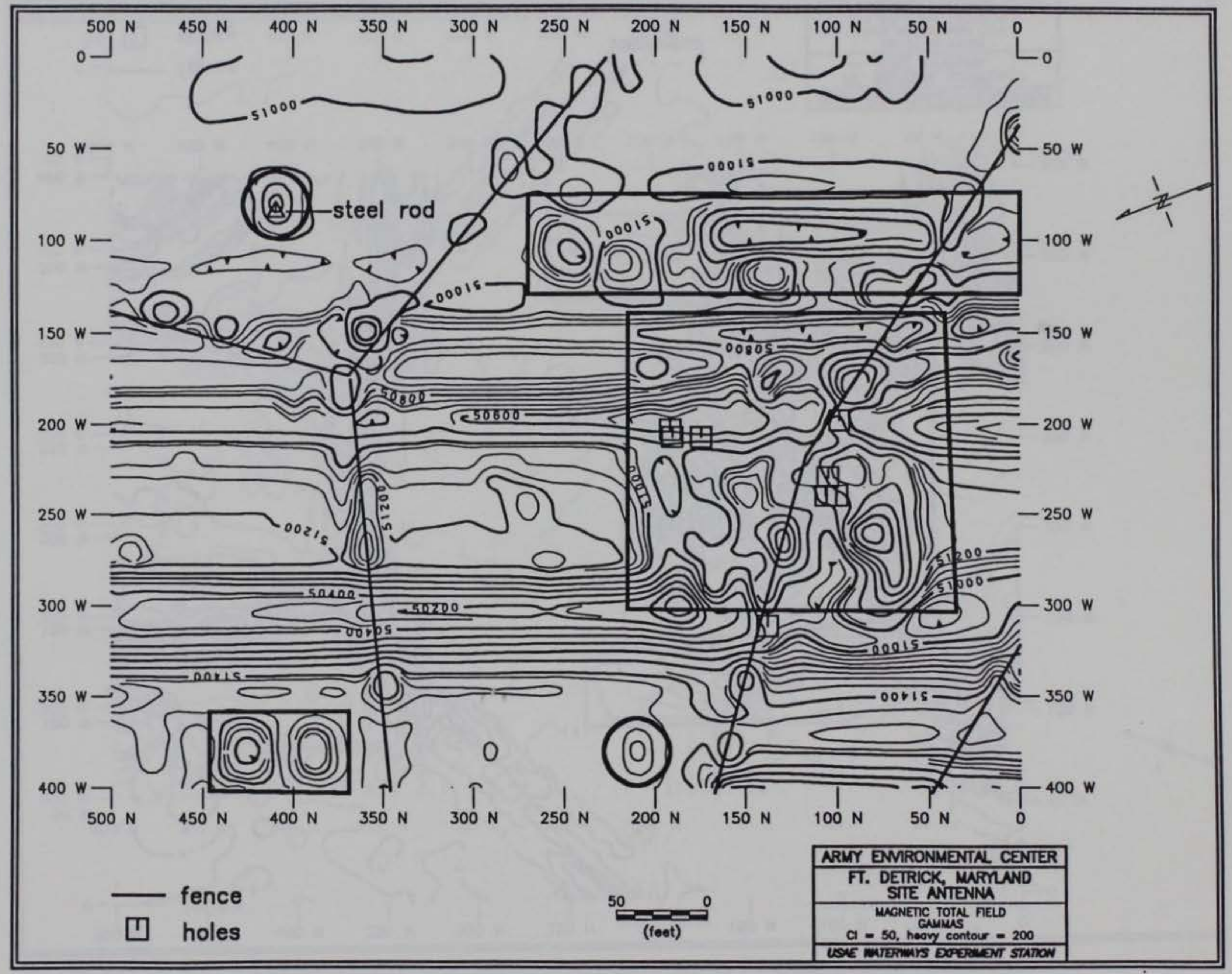

Figure 66. Antenna Site total magnetic field survey results 


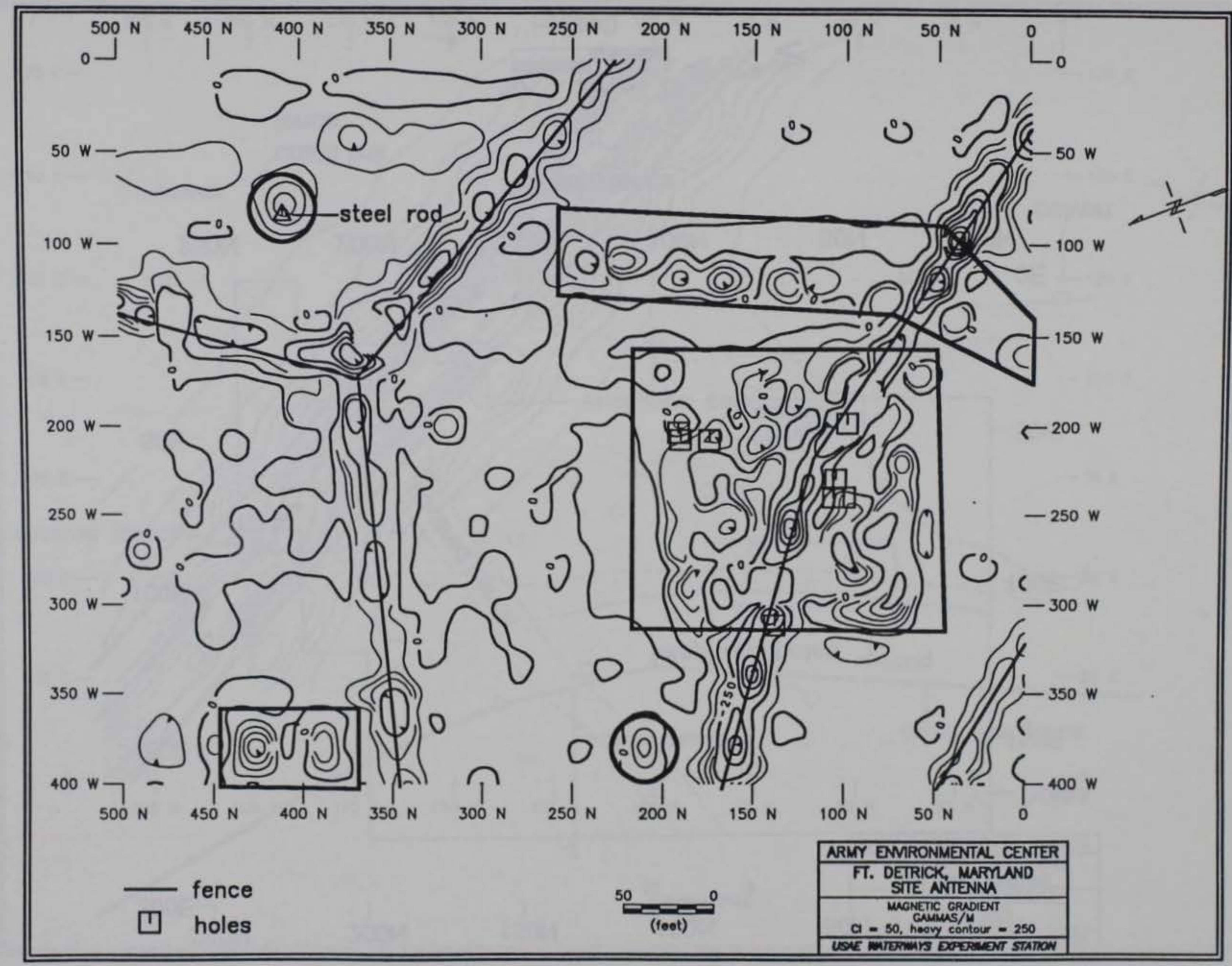

Figure 67. Antenna Site magnetic gradient survey results 


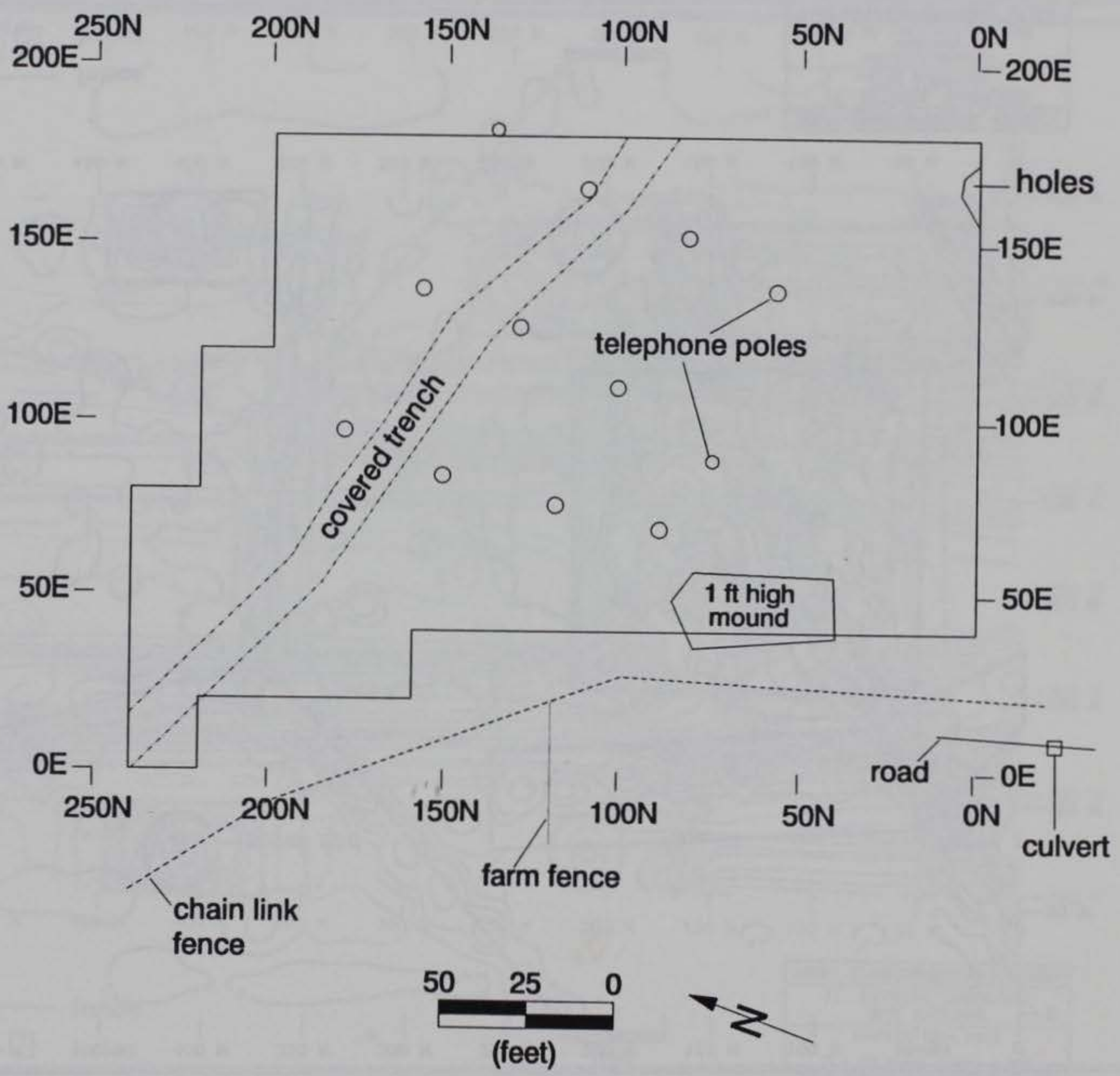

Figure 68. Army Reserve Site map 


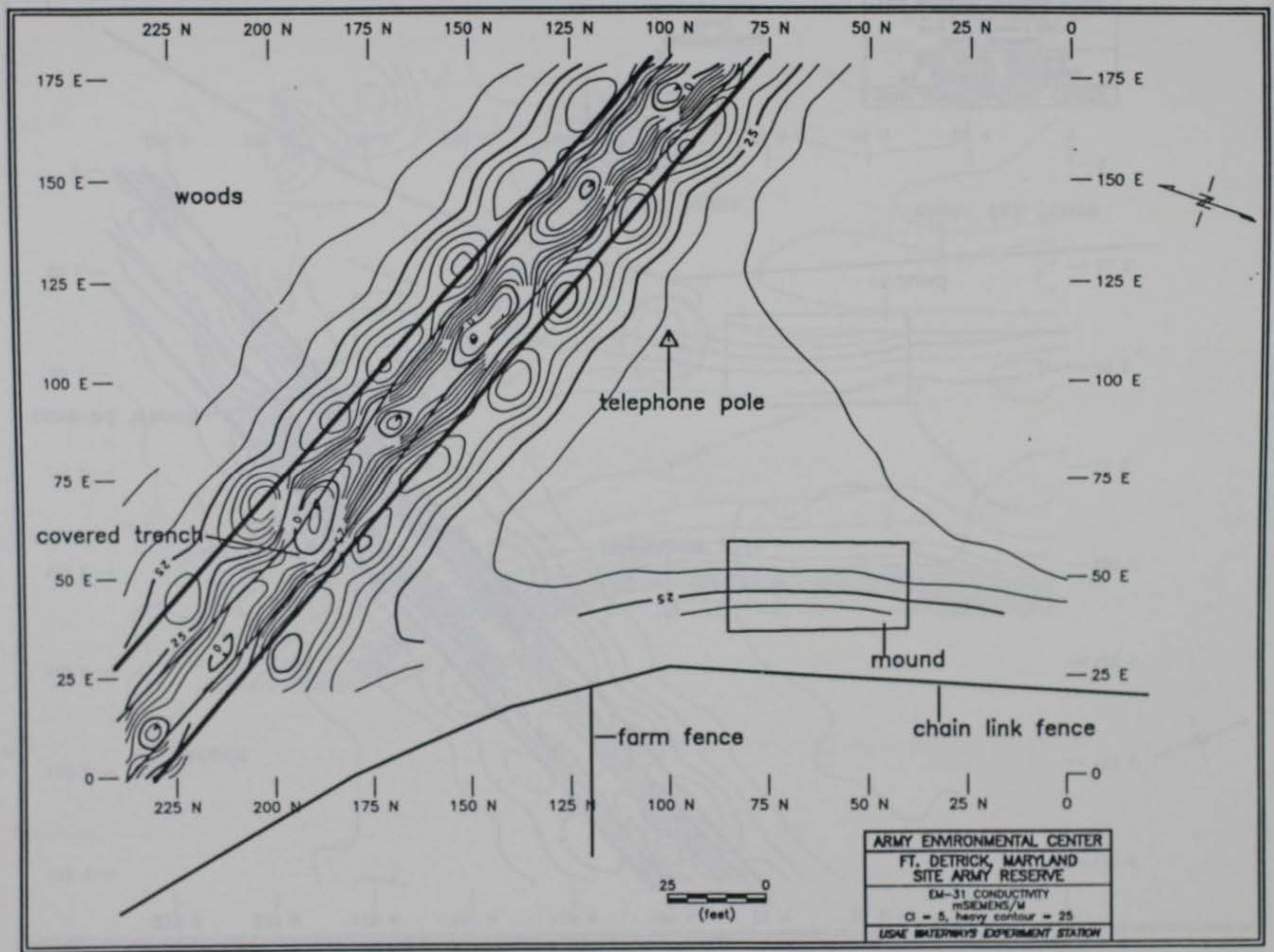

Figure 69. Army Reserve Site conductivity results 


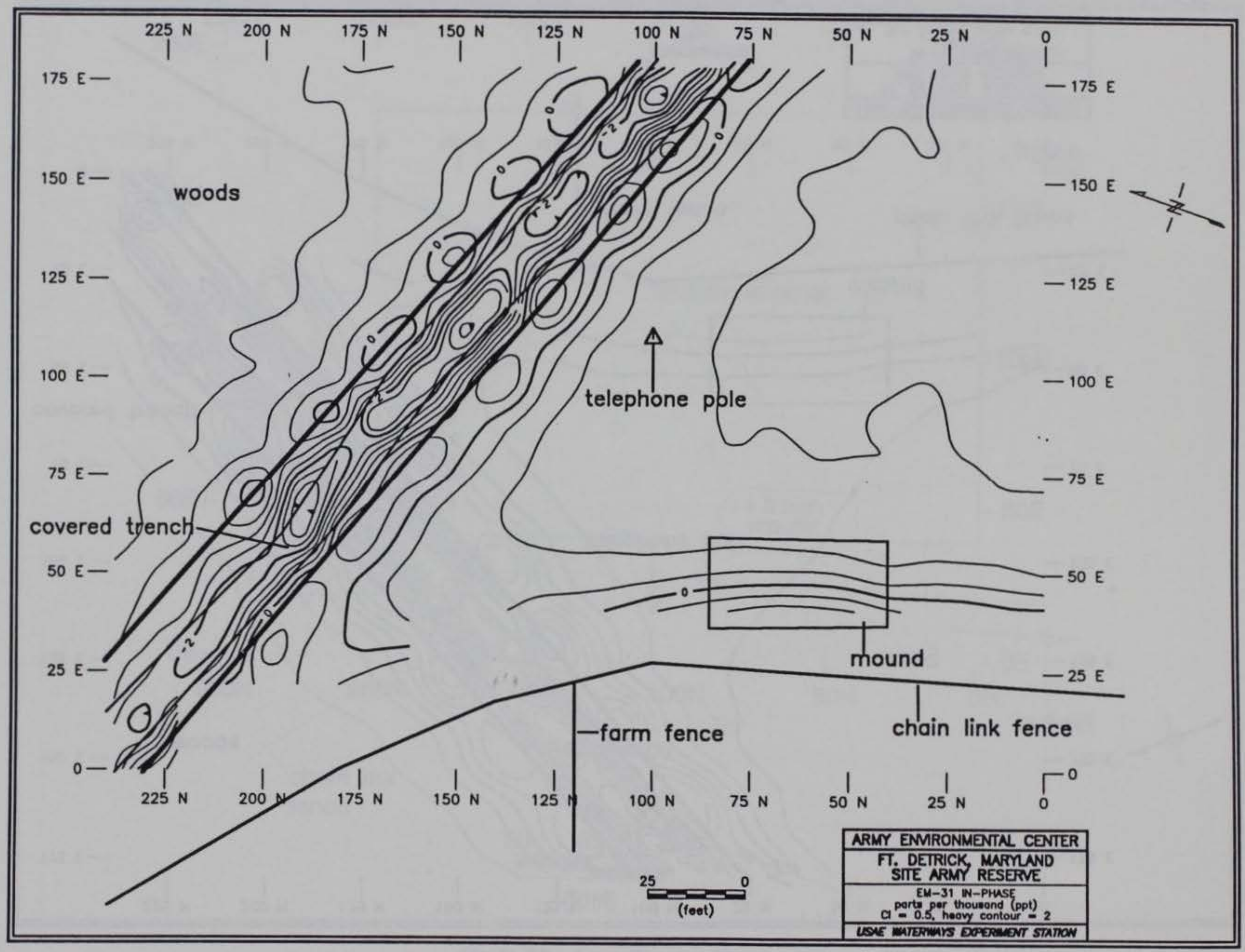

Figure 70. Army Reserve Site in-phase results 


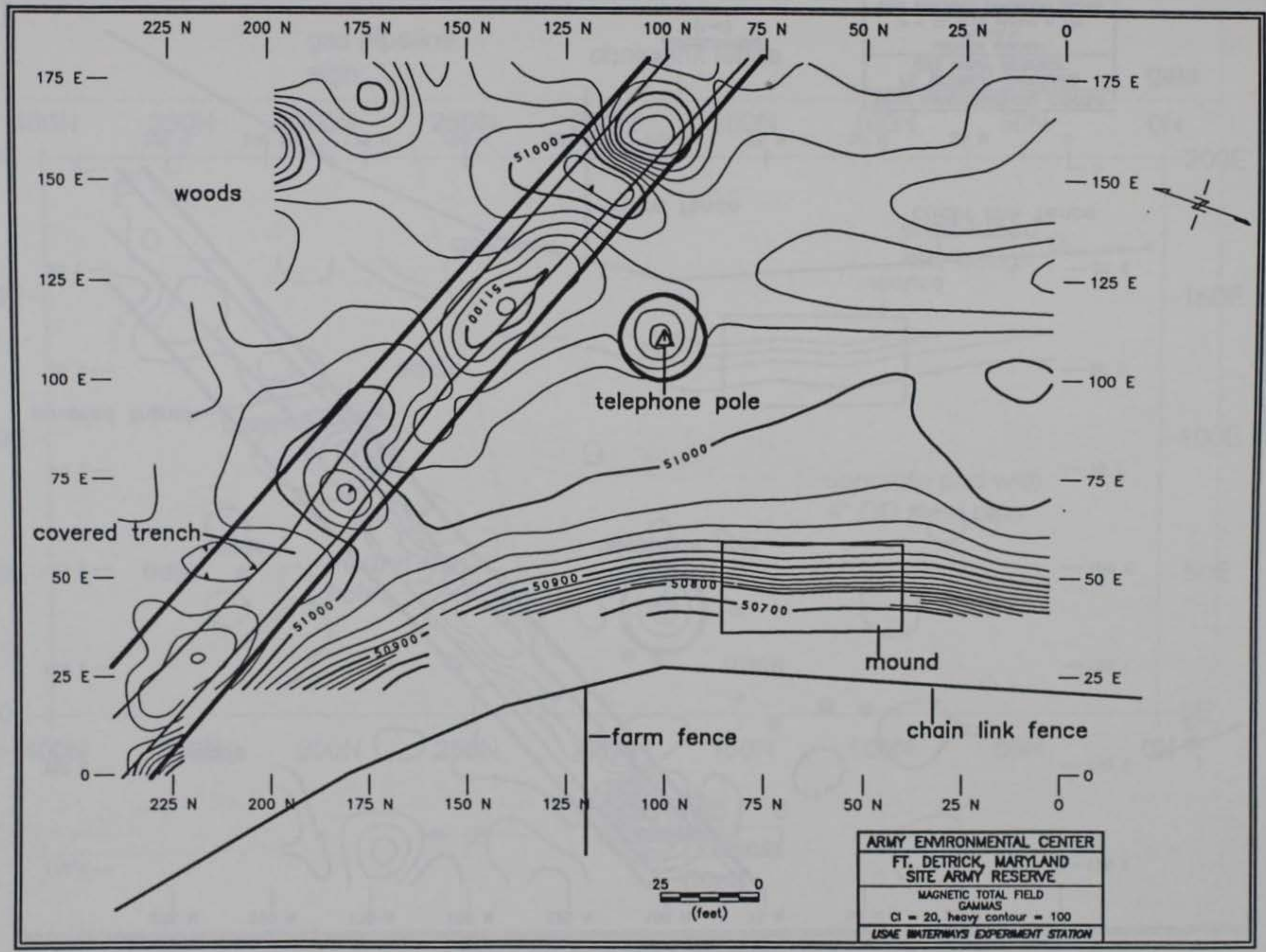

Figure 71. Army Reserve Site total magnetic field survey results 


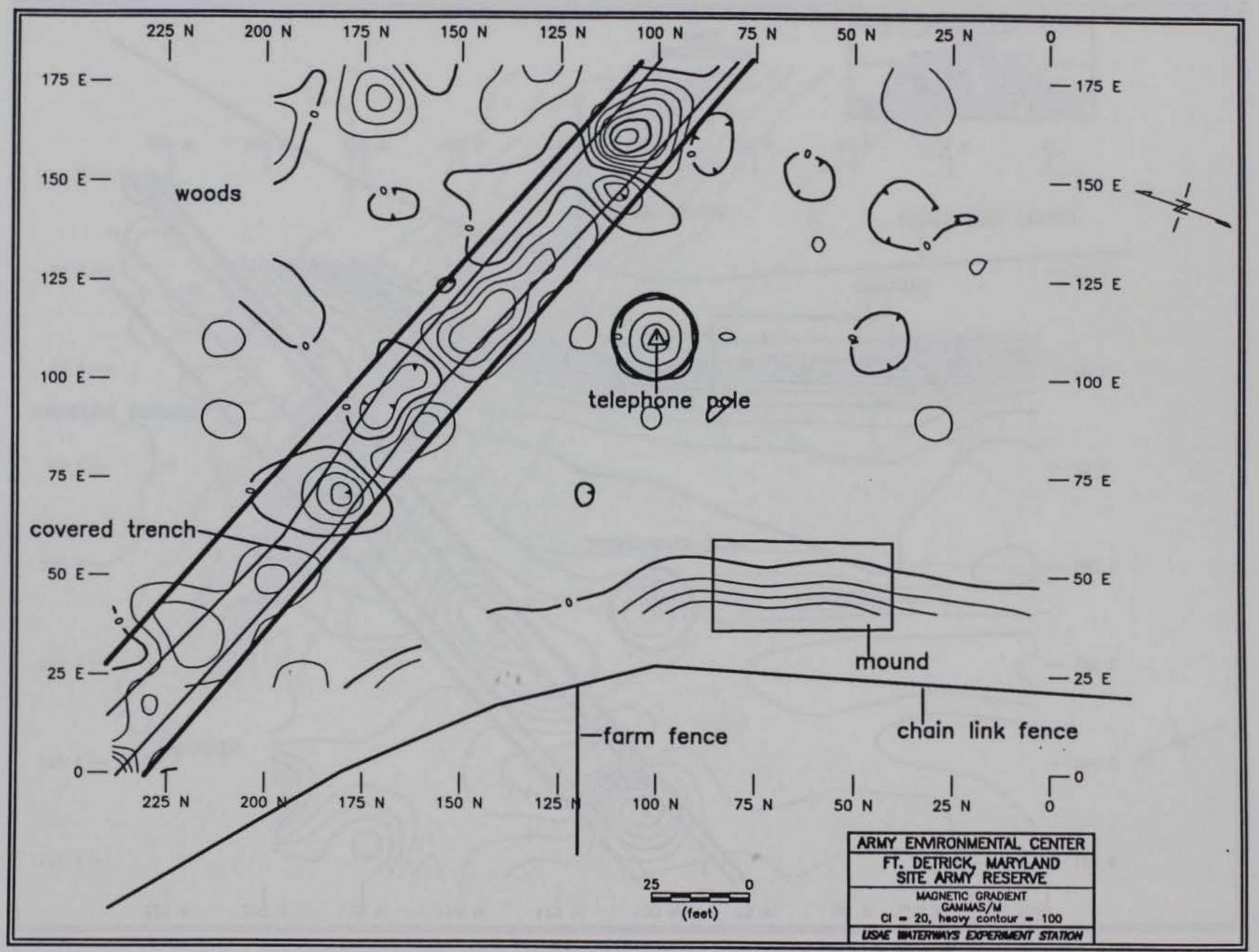

Figure 72. Army Reserve Site magnetic gradient survey results 


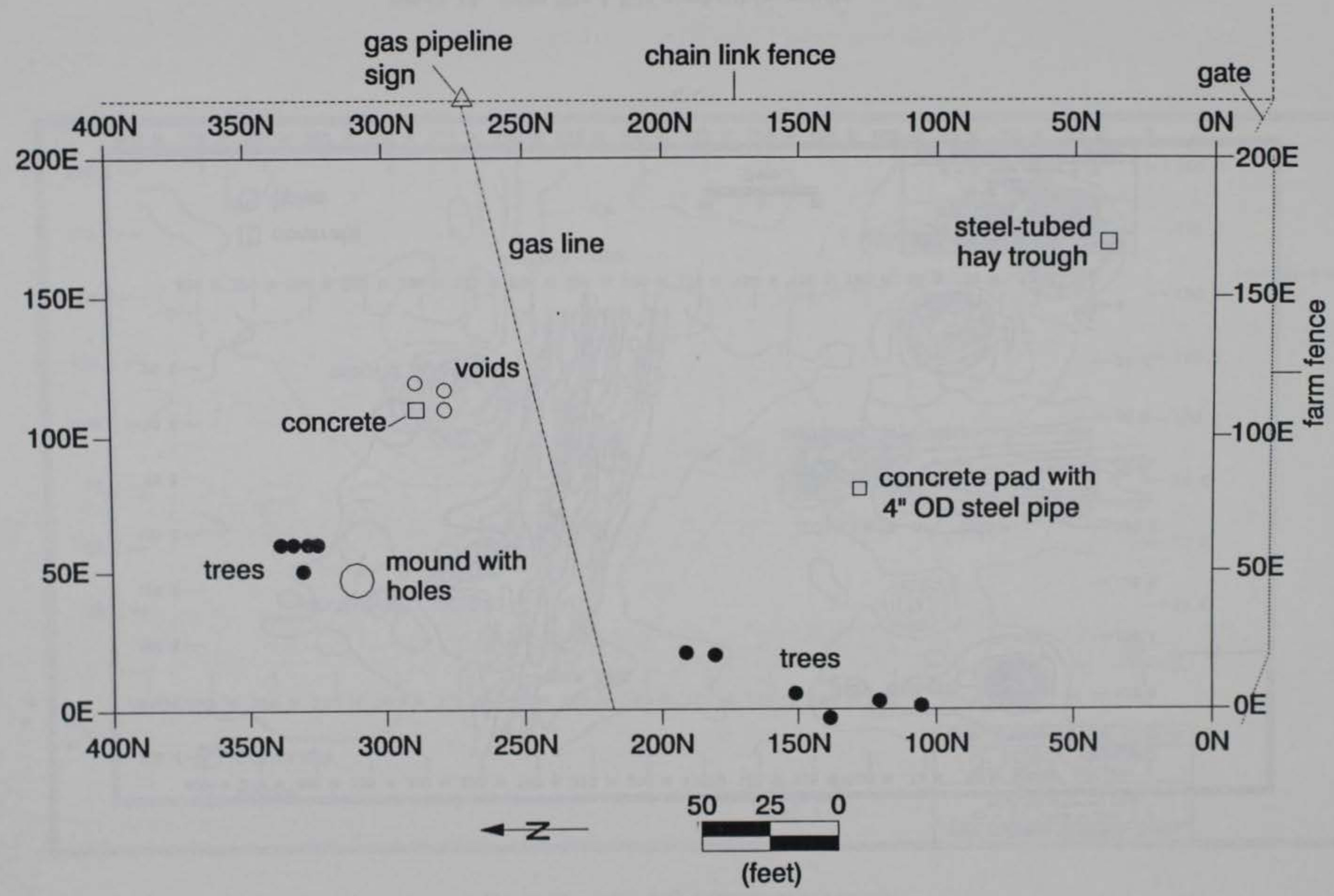

Figure 73. Igloo Site 1 Site map 


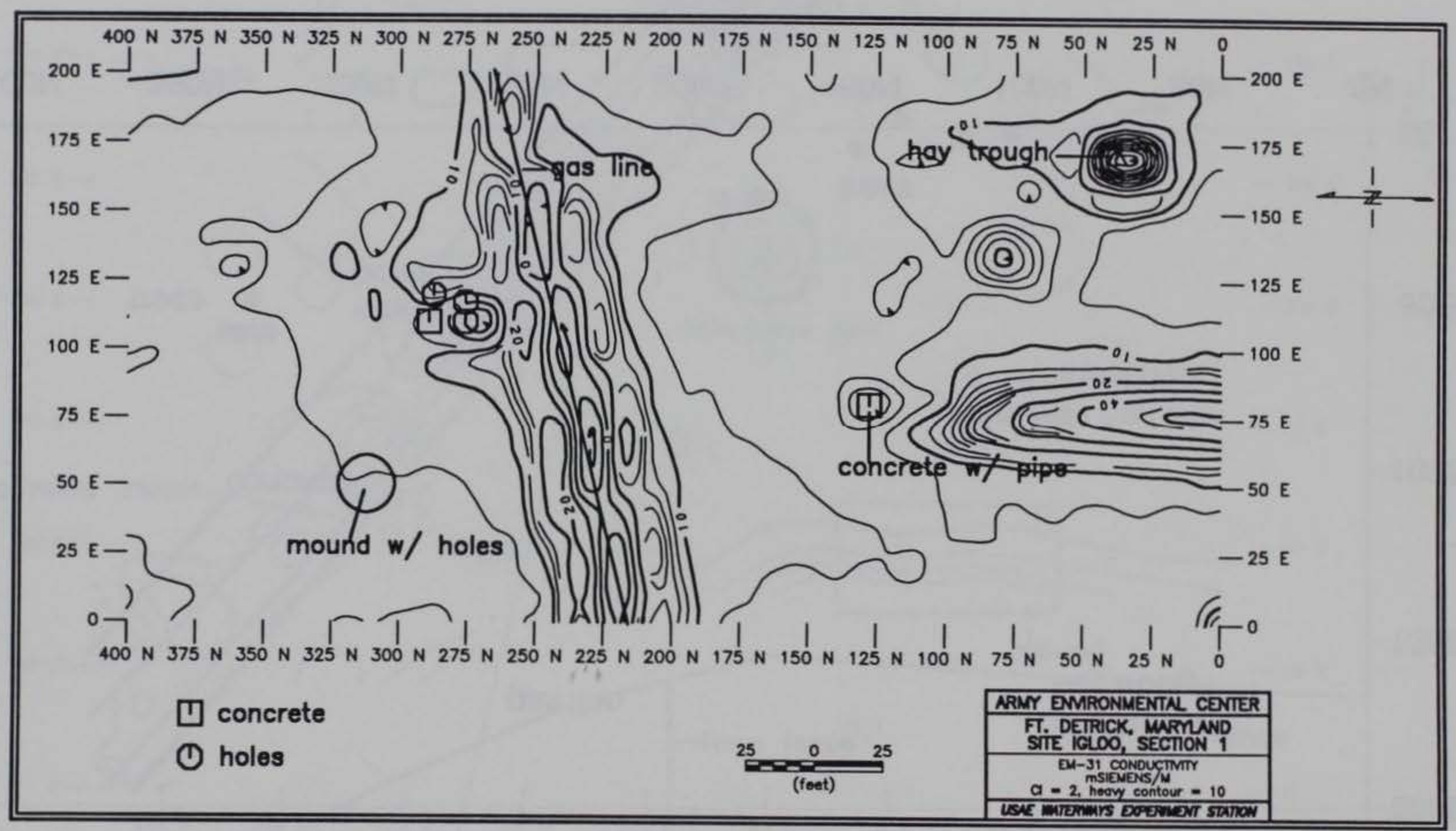

Figure 74. Igloo Site 1 Site conductivity results 


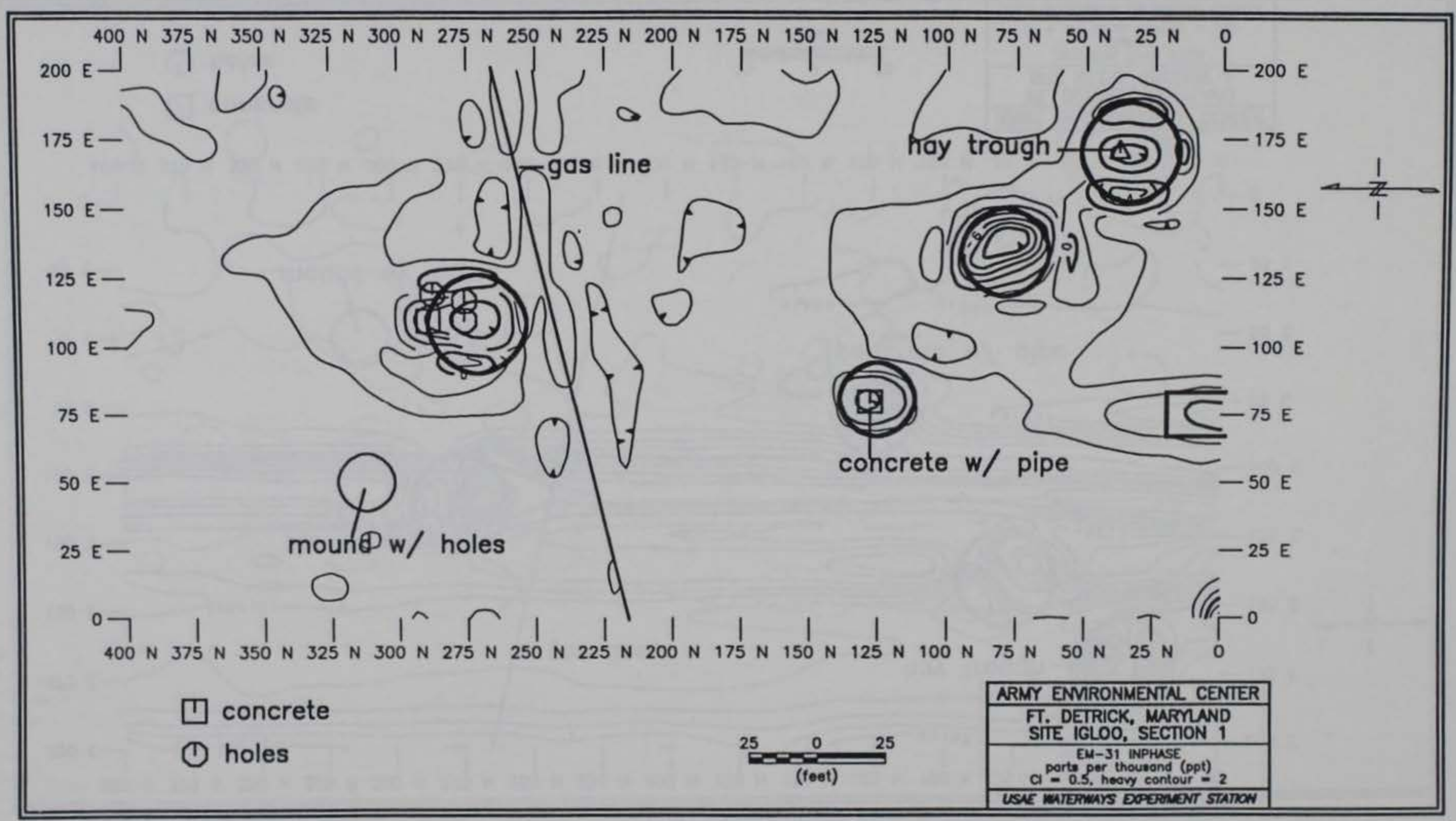

Figure 75. Igloo Site 1 Site in-phase results 


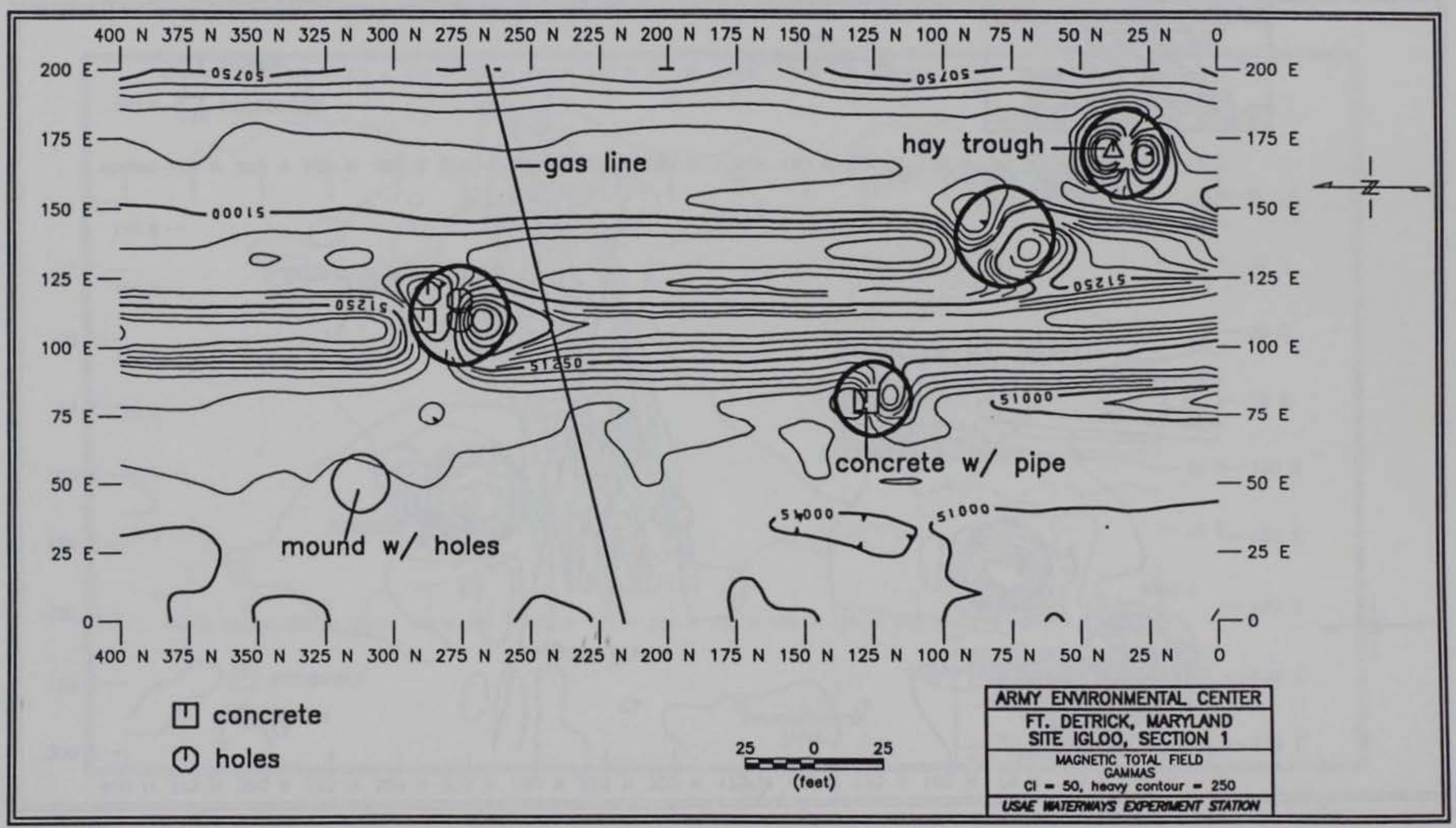

Figure 76. Igloo Site 1 Site total magnetic field survey results 


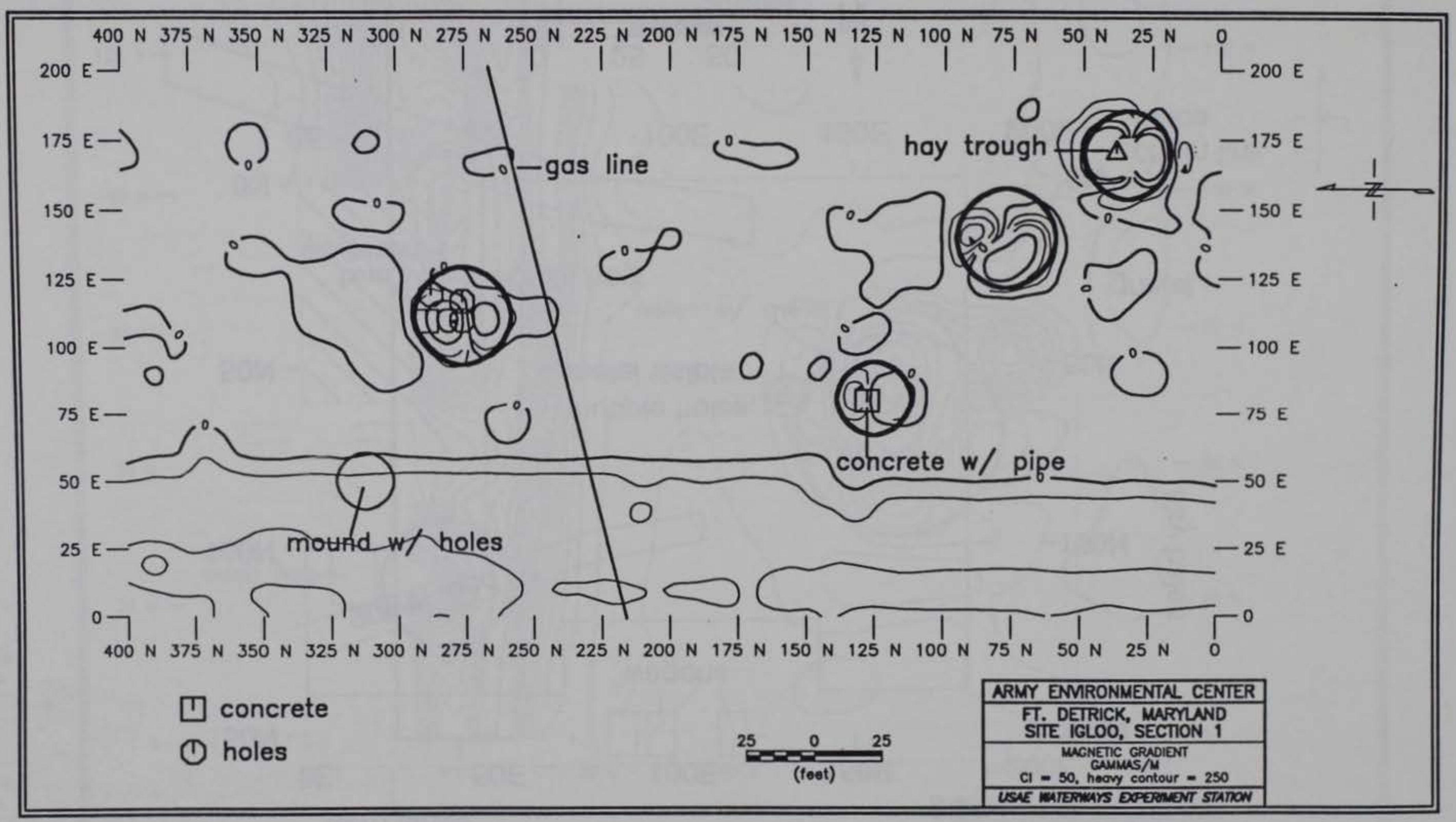

Figure 77. Igloo Site 1 Site magnetic gradient survey results 


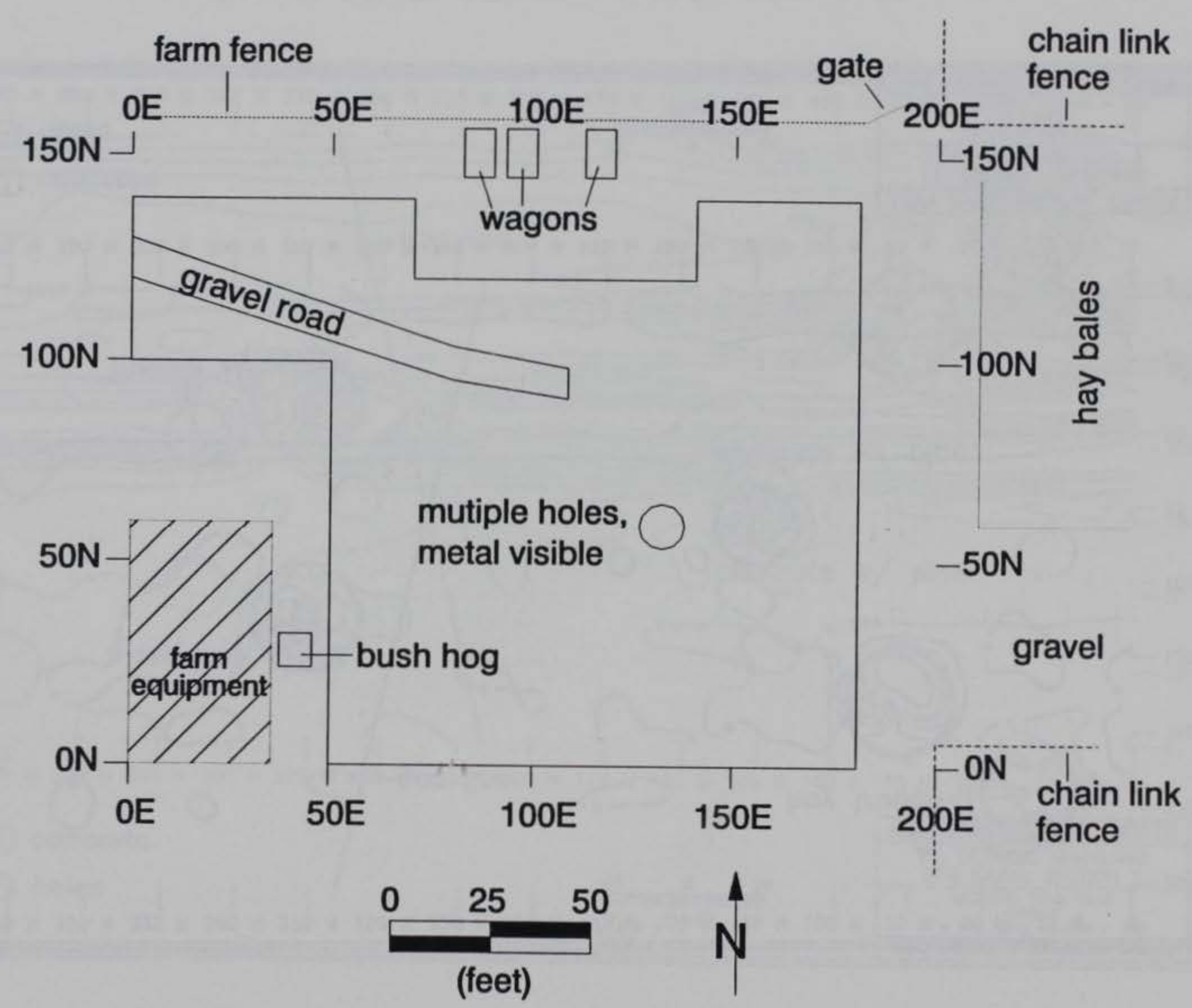

Figure 78. Igloo Site 2 Site map 


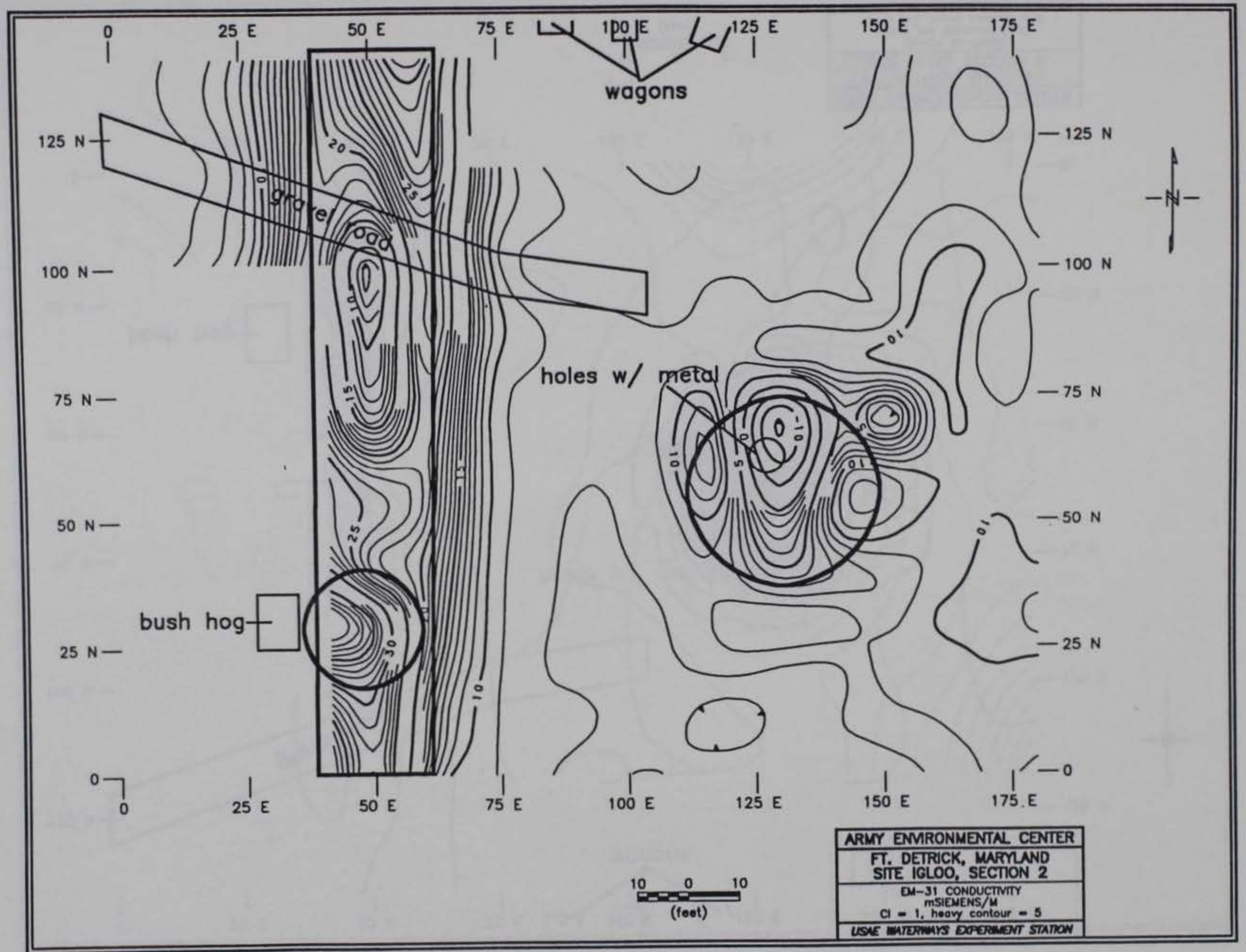

Figure 79. Igloo Site 2 Site conductivity results 


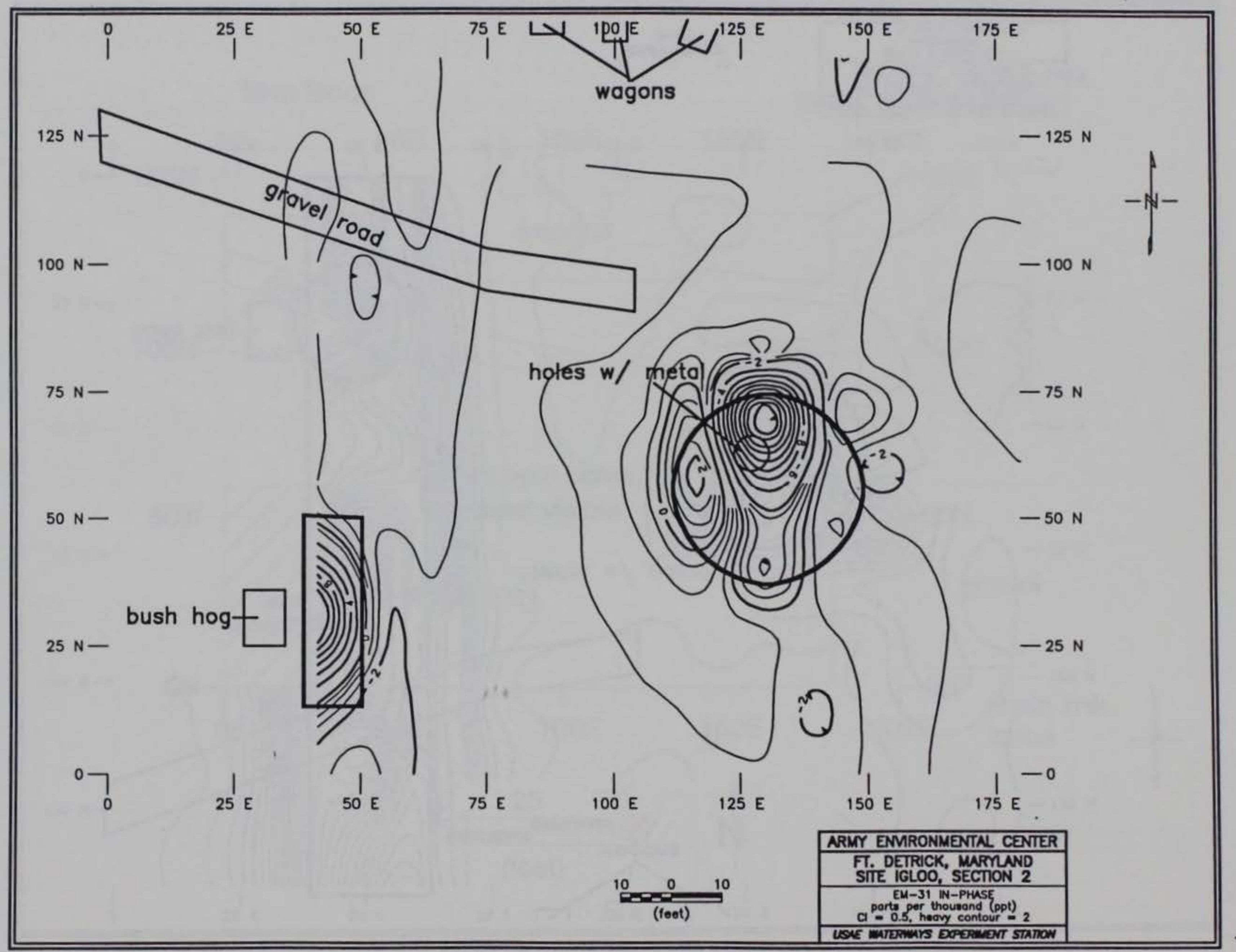

Figure 80. Igloo Site 2 Site in-phase results 


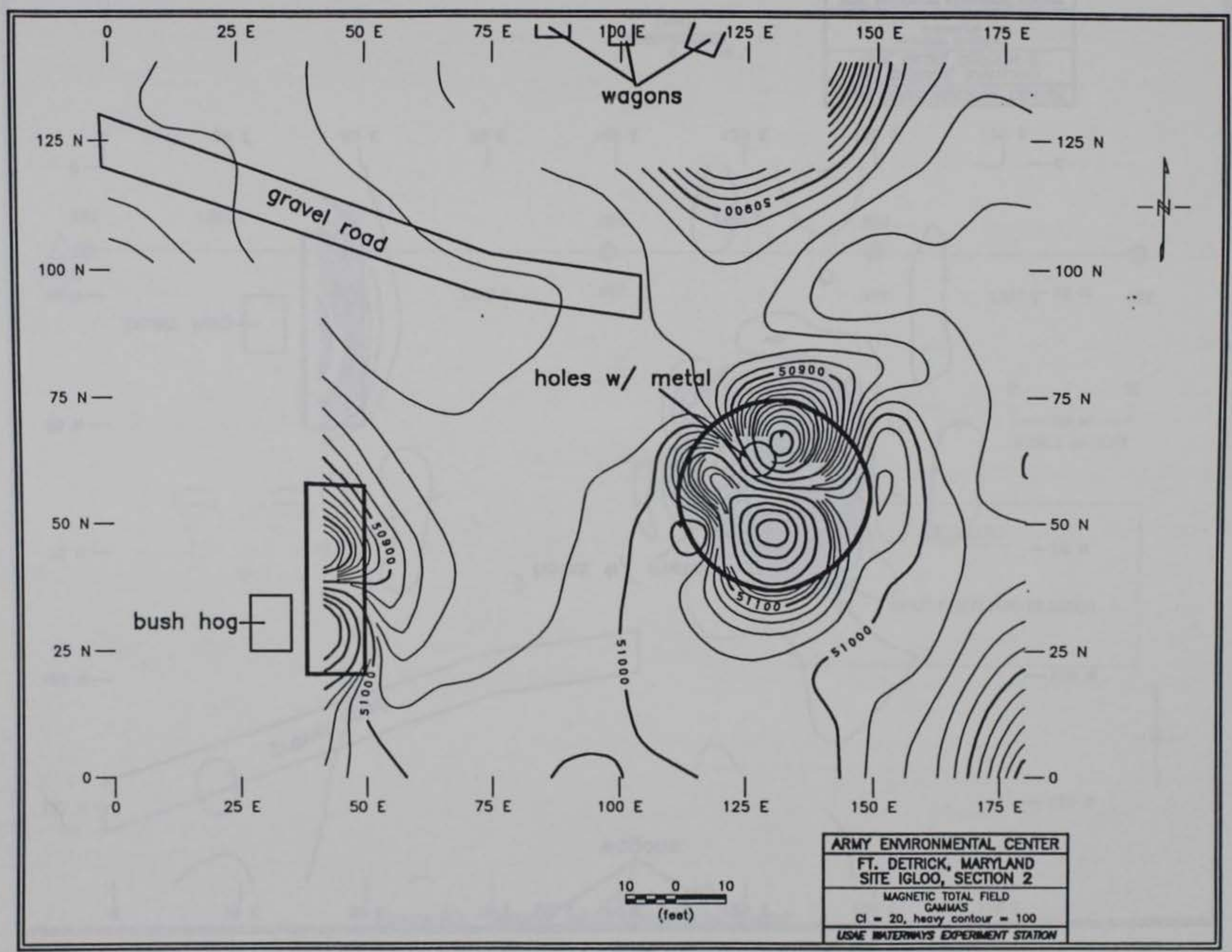

Figure 81. Igloo Site 2 Site total magnetic field survey results 


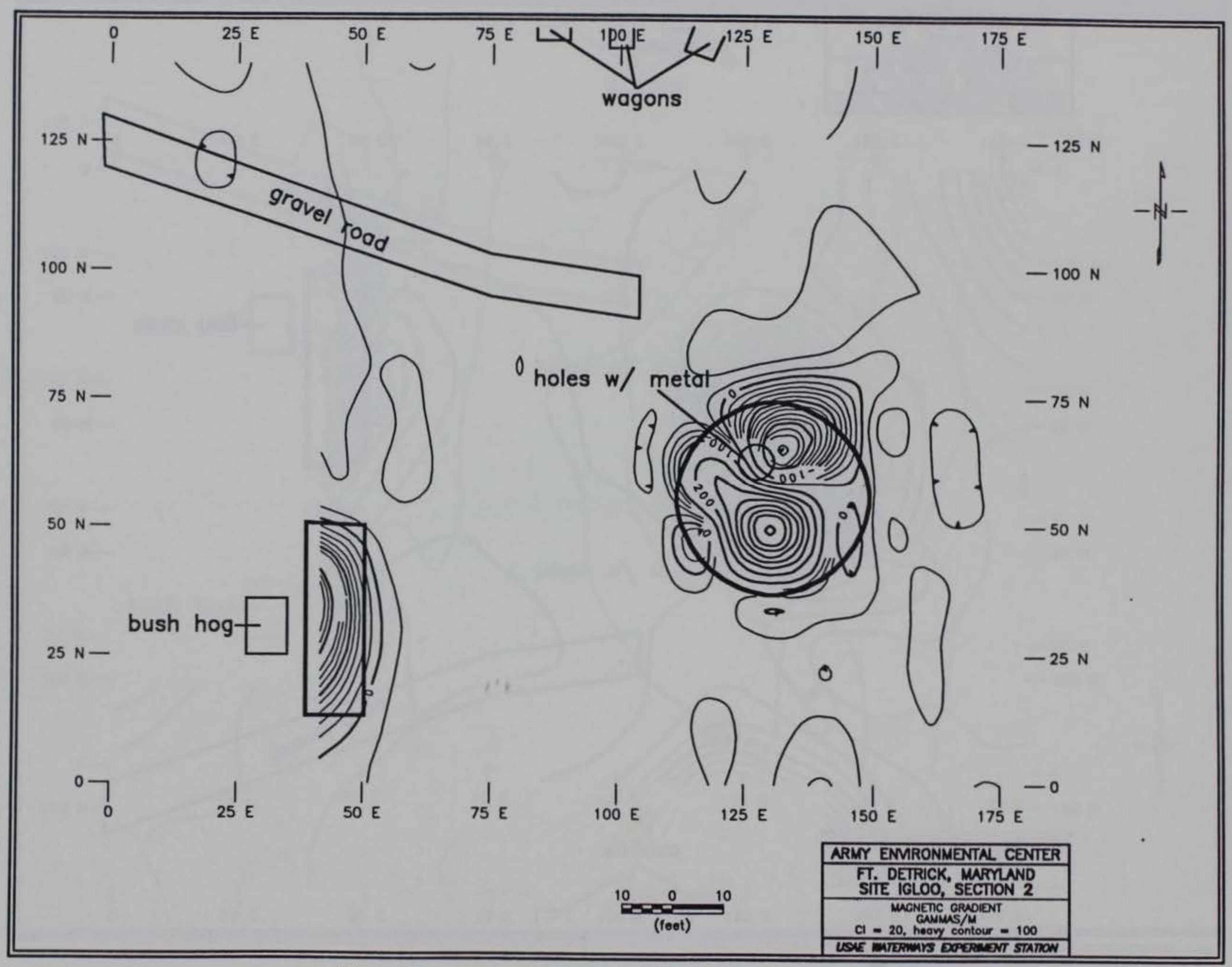

Figure 82. Igloo Site 2 Site magnetic gradient survey results 


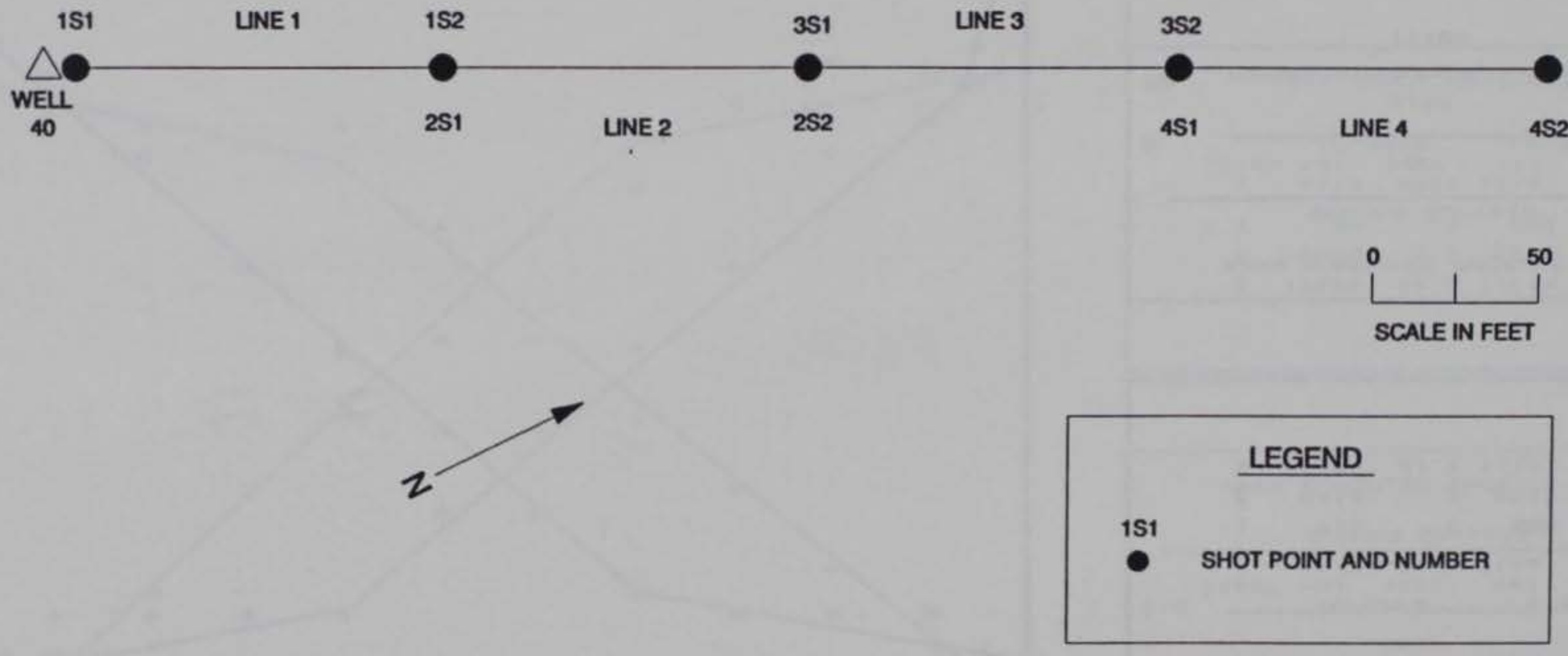

Figure 83. Seismic refraction survey layout 

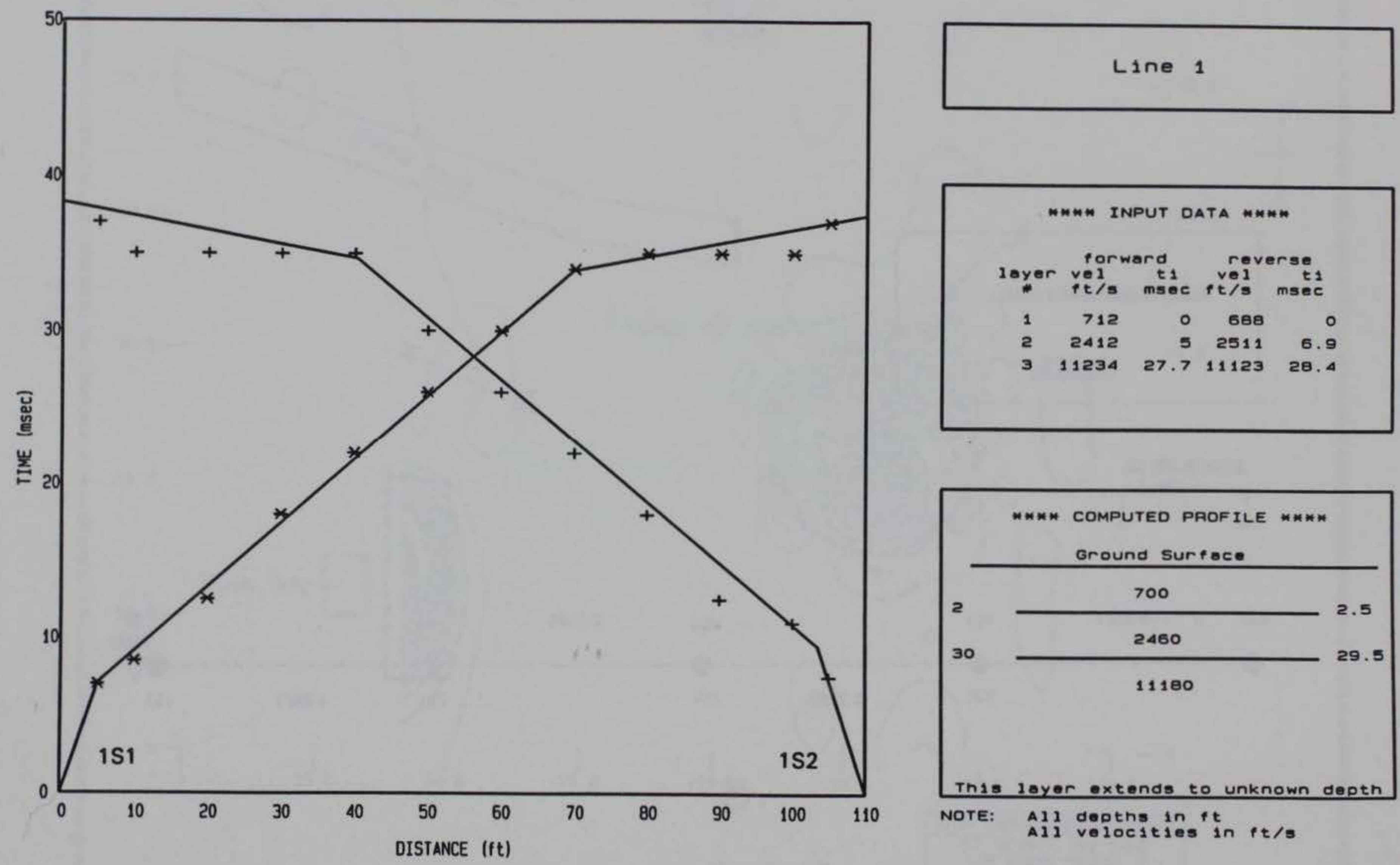

Figure 84. Time versus distance plot for seismic refraction Line 1 

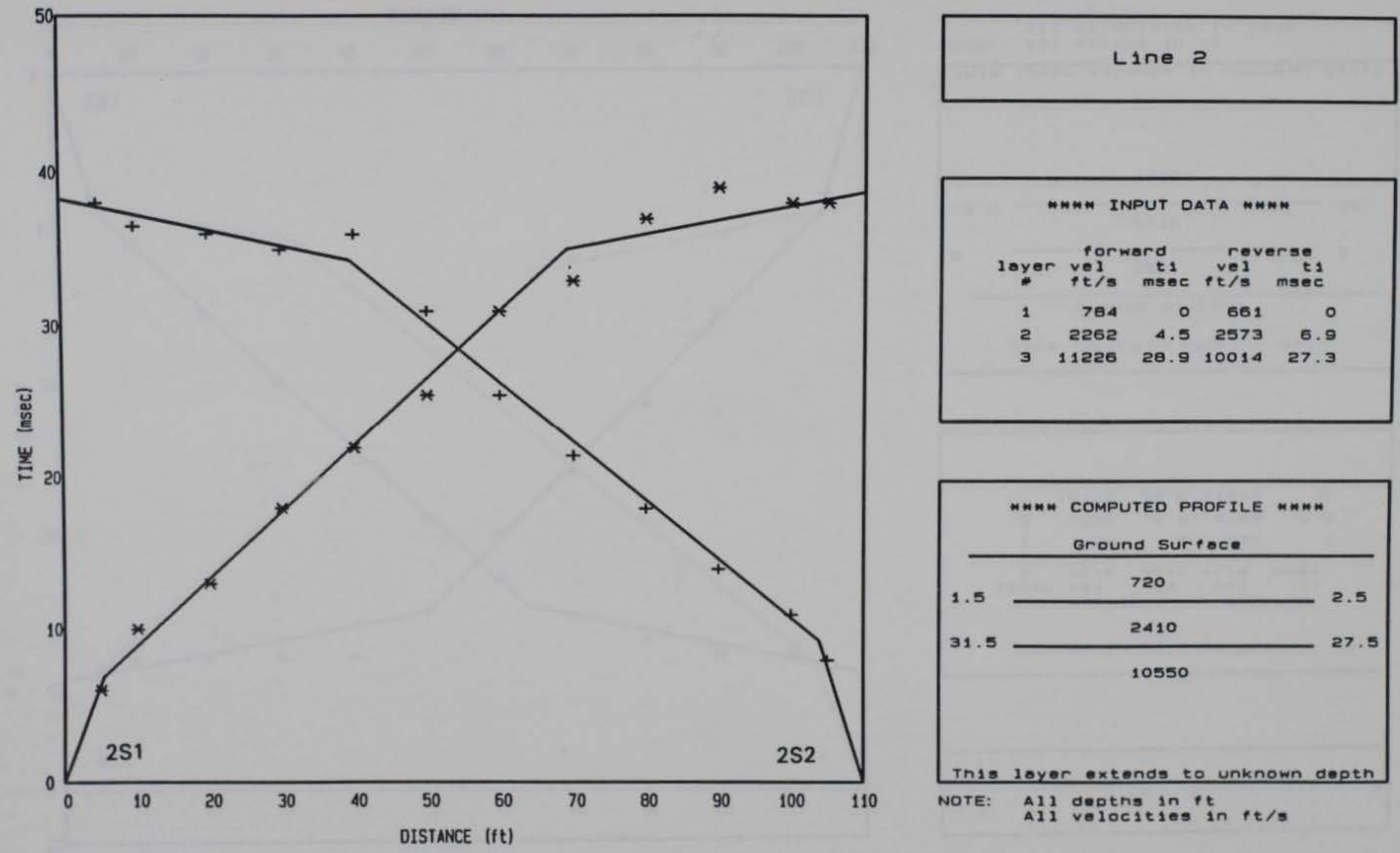

Figure 85. Time versus distance plot for seismic refraction Line 2 

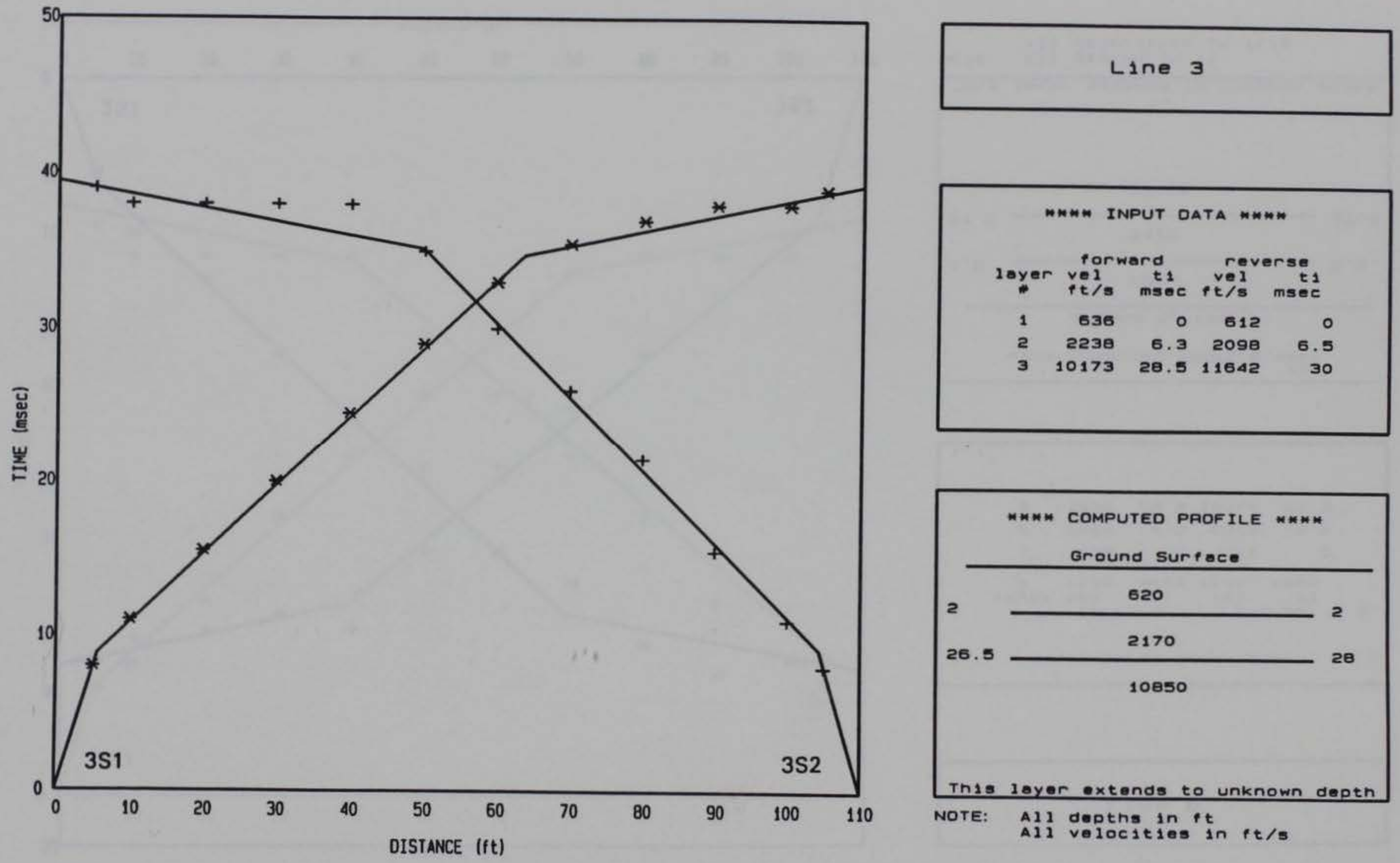

Figure 86. Time versus distance plot for seismic refraction Line 3 

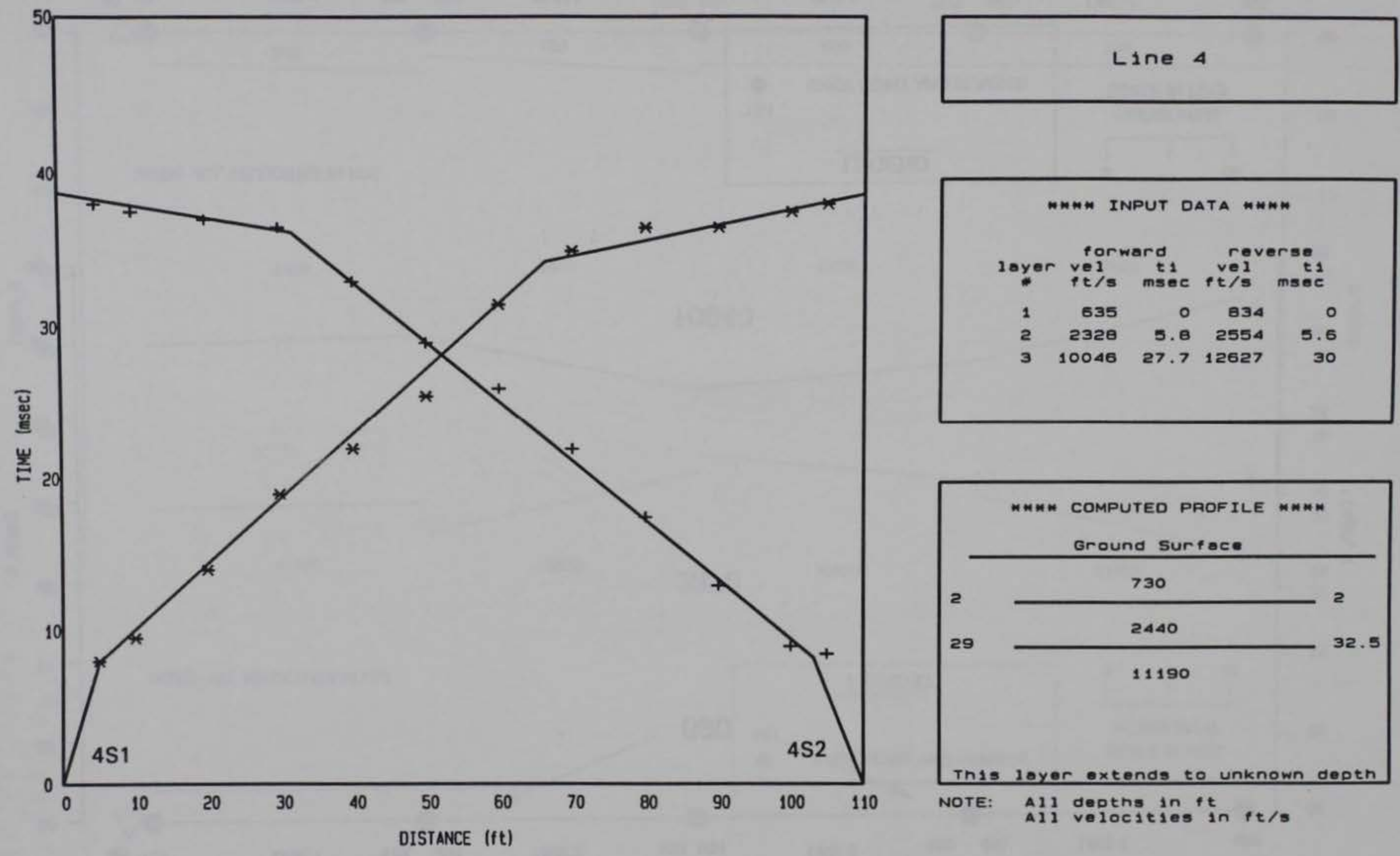

Figure 87. Time versus distance plot for seismic refraction Line 4 


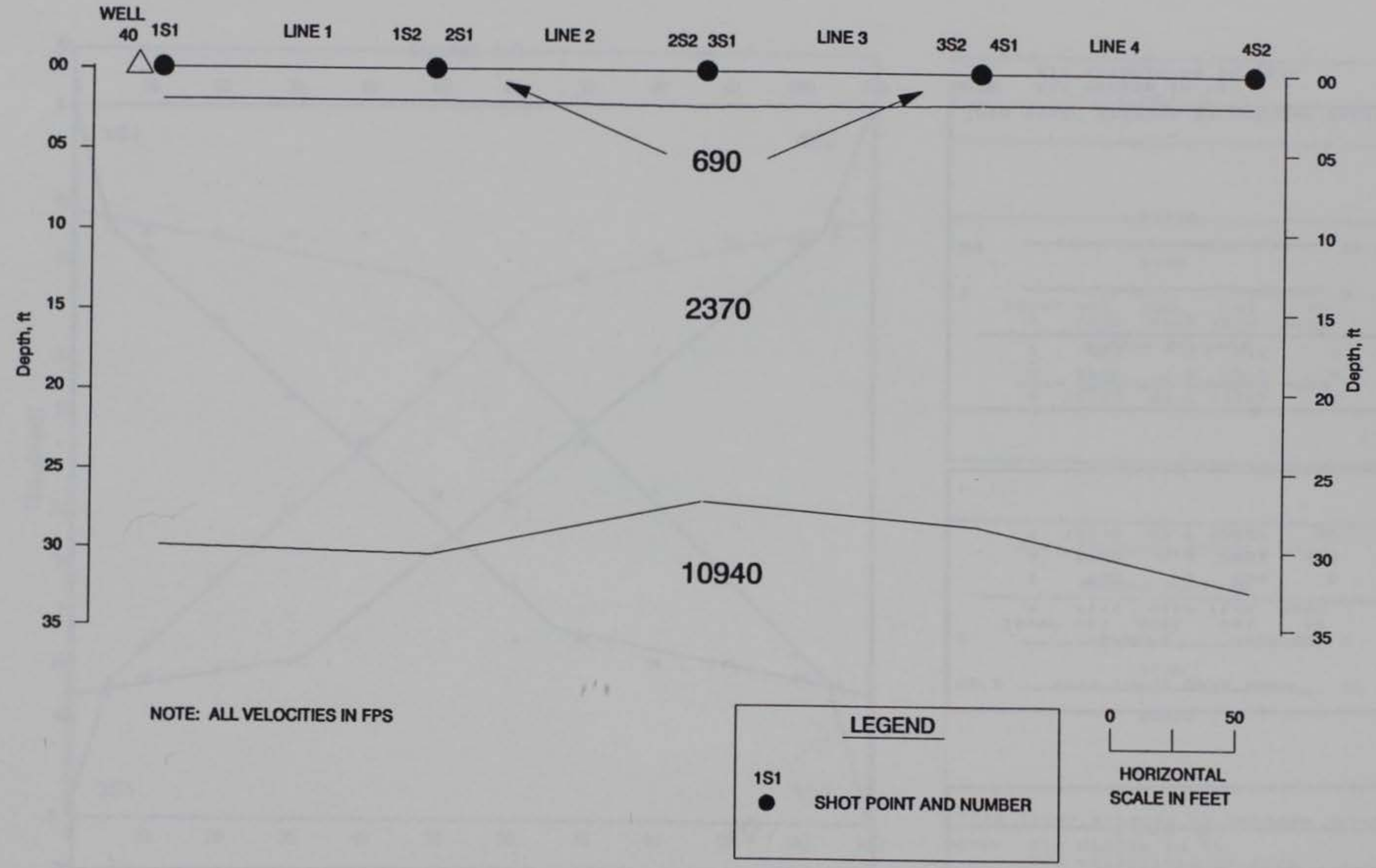

Figure 88. P-wave velocity profile for seismic refraction Lines 1-4 


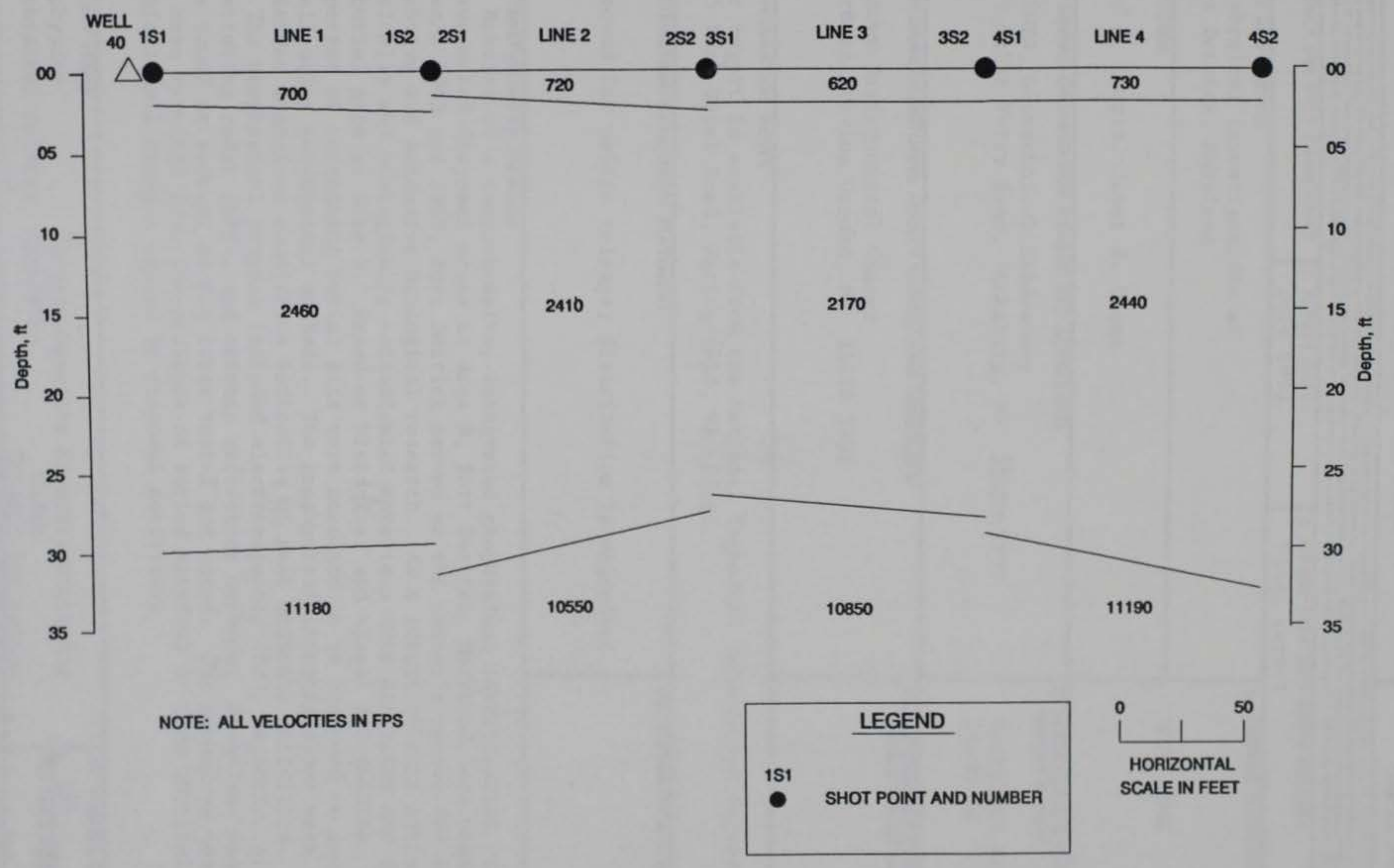

Figure 89. Averaged P-wave velocity profile for seismic refraction Lines 1.4 
Public reporting burden for this collection of information is estimated to average I hour per response, inciuding the time for reviewing instructions, searching existing data sources. gathering and maintaining the data needed, and completing and reviewing the collection of information, Send comments regarding this burden estimate or any other aspect of this

\begin{tabular}{|l|l|l|}
\hline 1. AGENCY USE ONLY (Leave blank) & $\begin{array}{c}\text { 2. REPORT DATE } \\
\text { July } 1993\end{array}$ & $\begin{array}{c}\text { 3. REPORT TYPE AND DATES COVERED } \\
\text { Final report }\end{array}$ \\
\hline
\end{tabular}

4. TITLE AND SUBTITLE

Geophysical Investigations at

Fort Detrick, Maryland

Jose' L. Llopis, Janet E. Simms

\section{PERFORMING ORGANIZATION NAME(S) AND ADDRESS(ES)}

USAEWES, Geotechnical Laboratory

3909 Halls Ferry Road, Vicksburg, MS 39180-6199
MIPR 7082
5. FUNDING NUMBERS

GATION REPORT NUMBER

Technical Report GL-93-14

10. SPONSORING/MONITORING AGENCY REPORT NUMBER

US Army Environmental Center

Aberdeen Proving Ground, MD 21010-5401

\section{SUPPLEMENTARY NOTES}

This report is available from the National Technical Information Service, 5285 Port Royal Road, Springfield, VA 22161.

\section{2a. DISTRIBUTION/AVAILABILITY STATEMENT}

12b. DISTRIBUTION CODE

Approved for public release; distribution is unlimited

\section{ABSTRACT (Maximum 200 words)}

Results of a comprehensive, integrated geophysical investigation of 15 suspected disposal areas at Area B, Fort Detrick, Maryland, are presented. Between 1943 and 1969 , Fort Detrick served as the nation's center for military offensive and defensive biological research. As a result of this activity, chemically and biologically contaminated materials were generated and disposed in burial pits at Site B. Based on historical and visual information, 15 sites suspected of containing burial pits were selected to be examined in greater detail using geophysical methods. The geophysical investigations were designed to detect anomalous conditions indicative of past disposal activities.

The geophysical program included electromagnetic (EM), magnetic, ground penetrating radar (GPR), and seismic refraction methods. Anomalous conditions were found at several of the sites tested and noted. The anomalous conditions may have resulted from the presence of buried material or from physical and/or chemical soil changes caused by disposal activities.

\begin{tabular}{|c|c|c|}
\hline 14. SUBJECT TERMS & & \\
\hline $\begin{array}{l}\text { Geophysics } \\
\text { Geophysical surveys }\end{array}$ & $\begin{array}{l}\text { Electromagnetics } \\
\text { Magnetics }\end{array}$ & $\begin{array}{l}\text { Ground penetrating } \\
\text { radar } \\
\text { Seismic refraction }\end{array}$ \\
\hline
\end{tabular}

\begin{tabular}{|l|l|l|l|}
\hline $\begin{array}{l}\text { 17. SECURITY CLASSIFICATION } \\
\text { OF REPORT } \\
\text { UNCLASSIFIED }\end{array}$ & $\begin{array}{l}\text { 18. SECURITY CLASSIFICATION } \\
\text { OF THIS PAGE } \\
\text { UNCALSSIFIED }\end{array}$ & $\begin{array}{l}\text { 19. SECURITY CLASSIFICATION } \\
\text { OF ABSTRACT }\end{array}$ \\
\hline
\end{tabular}

15. NUMBER OF PAGES 128

16. PRICE CODE 